\title{
A HISTORY OF FLY FISHING FOR TROUT BY JOHN WALLER HILLS
}
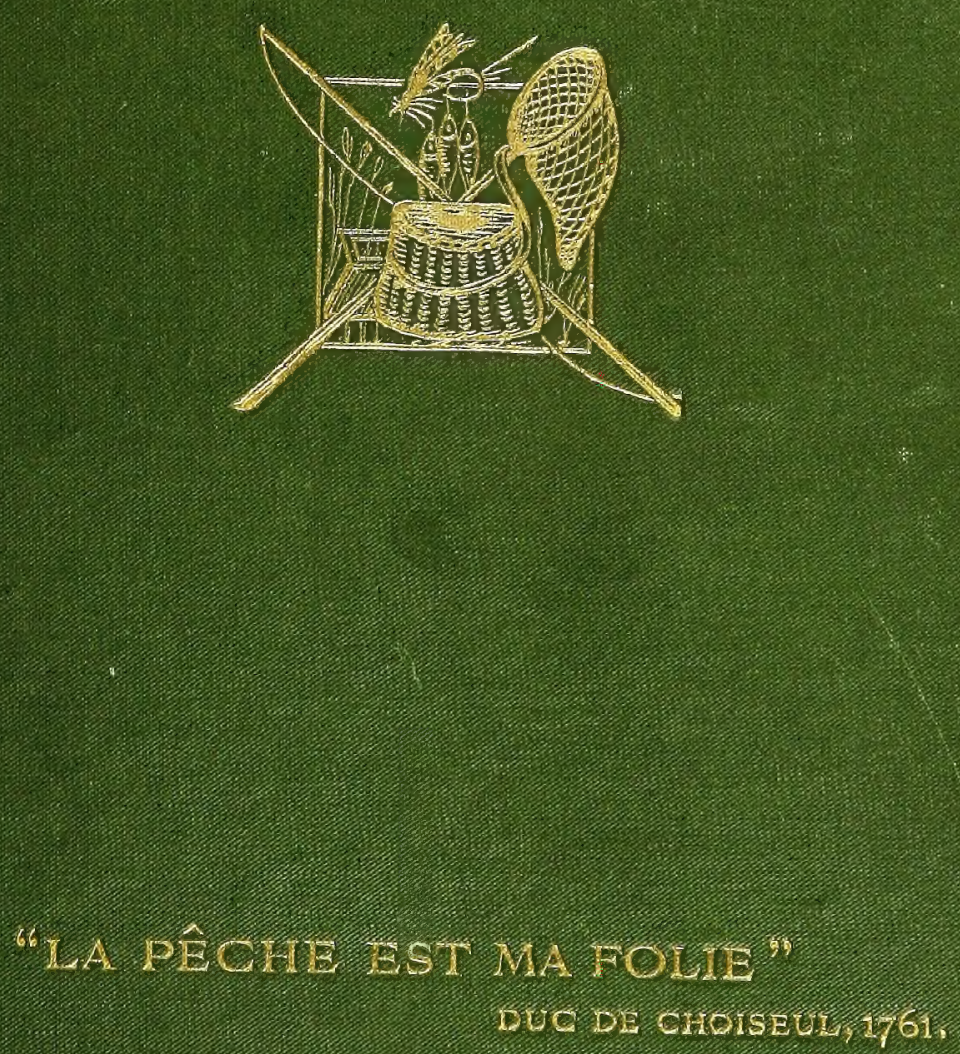


\section{ALBERT R. MANN}

LIBRARY

New York State Colleges

OF

Agriculture ANd Home Economics

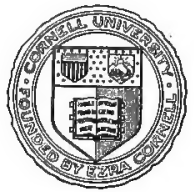

AT

Corneli University 


\section{SH 687.H65Hell University Library}

A history of fly fishing for trout,

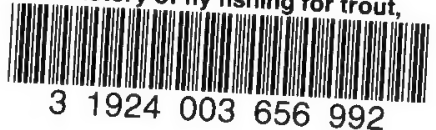




\section{Cornell University Library}

The original of this book is in the Cornell University Library.

There are no known copyright restrictions in the United States on the use of the text. 


\section{A \\ HISTORY \\ OF FLY FISHING \\ FOR TROUT}





\section{A HISTORY \\ OF FLY FISHING \\ FOR TROUT}

\section{BY \\ JOHN WALLER HILLS}

'La Pêche est ma folie'

Duc De Cholseul (176r)

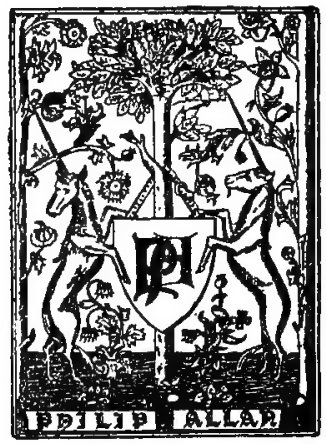

LONDON

PHILIP ALLAN \& CO. MDCCCCXXI 


$$
\begin{aligned}
& S H \\
& 687 \\
& H 65 H
\end{aligned}
$$

130454

Printed by Whitehead Brothres, Wolverhampton 


\section{CONTENTS.}

CHAPTER I.

PAGE

Sporting Literature in France and ENGLAND - $\quad$ - $\quad$ -

CHAPTER II.

The Treatise of Fishing with an ANGIE

CHAPTER III.

From the Treatise to the Compleat ANGLER

CHAPTER IV.

Early Fly Fishing in France -

CHAPTER $\nabla$.

Charles Cotton and his ContemPORARIES - - 56

CHAPTER VI.

From Cotton to Stewart - $\quad$ - 82 CHAPTER VII.

Stewart and the Upstream School - 


\section{CONTENTS-(Continued).}

\section{CHAPTER VIII.}

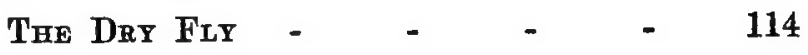

CHAPTER IX.

The Evolution of the Trodt Fry - 141

CHAPTER $\mathrm{X}$.

The Evoldtion of the Trodt Fly 170

(Contd.)

CHAPTER XI.

The Literatdre of Fif Fishing - 191

BIBLIOGRAPHY

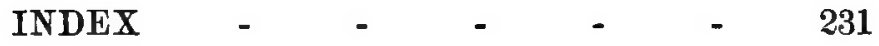




\section{ERRATA.}

Page 1, line 2 of quotation, for the first 'it,' read 'he.'

, 161, line 17, for is, read it.

"164, line 22, for down of a black water dog or of, read fur of a a black water dog or down of.

"181, line 1, for best, read better.

, 191, line 1 of quotation, for arivéd, read arriued.

" " " 4 of quotation, for think, read thinke.

, 219, line 11, for admirable, read admirably.

„228, line 26, for lakes, read lochs. 





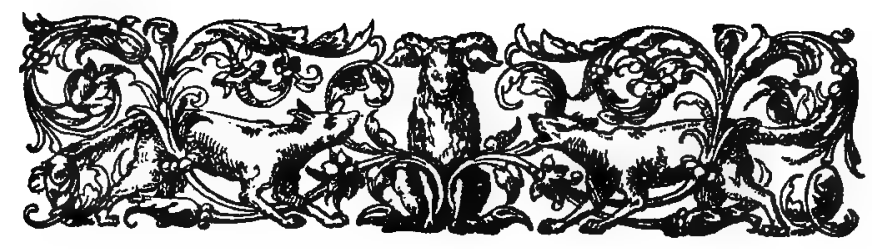

\section{CHAPTER I.}

\section{SPORTING LITERATURE IN FRANCE AND ENGIAND.}

The sport is so royal that there is neither gentle nor villein, if it knew of it and loved it well, who would not be more honoured for that reason by all who understand it.

Good Sir, if all knew it, would it be less honoured than it is now?

Nay, rather it would be more honoured, fair gentle friend, know it well.

La Chace dou Serf. About 1250.

'Translation by Sir Henry Dryden.

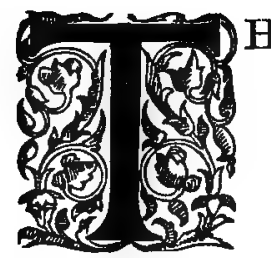

$\mathrm{HE}$ history of fly fishing begins at the close of the fifteenth century. It is true that there is one isolated record long before this; for the curious can carry its story back to the second century of our era and read in a Roman author an account of fly fishing for a fish, apparently the trout, in a river in Macedonia." But, while

"De Animalium Natura, by Claudius Aelianus, Book 15, Cap I. 
there is no reason to doubt the truth of this, the fact is interesting rather than important, and for this reason. It had no influence on subsequent development : it stands by itself, and was unknown until a modern writer quoted it as a curiosity. And as such we can leave it. We will merely give it a glance as we go by, this river of Macedon, which no doubt existed and no doubt held trout, for we have the best reason for knowing that there were salmon in it. The true history of fly fishing starts with the Treatise of Fishing with an Angle, attributed to Dame Juliana Berners and printed in $\mathbf{1 4 9 6}$ by Wynkyn de Worde, and is continuous to the present day. But we cannot understand the book or realise its measure and importance without regard to the age in which it appeared, and to the sporting literature out of which it arose.

England, rich though she is in books describing the pursuit of game, drew almost all that she knew from French origins. The sporting literature of Europe during the Middle Ages was almost exclusively French. If two easily remembered dates are taken, the signing of Magna Charta in 1215 and the battle of Agincourt exactly two centuries later, that period comprises everything that appeared upon sport before the earliest book on fishing was written. Now there were eight books of importance written during those two centuries. Of these five are entirely French, one other was 
written in Latin for Charles II., the Bourbon King of Sicily, and only two have any connexion with England. Moreover, of these two, only one springs from English soil, and that was written not in English but Norman French, while the other, the Master of Game, is a translation of a French work. When therefore the first book on fly fishing was written, shortly after the end of the period, for its date is certainly not later than 1450 and possibly. earlier, it came into the world against a background which was entirely French. It arose out of, and is deeply moulded and conditioned by, French writings; it is their offspring, and could be that of none other. Neither its form nor still less its spirit can be understood unless something is known of the literature of sport during those two centuries: something of the books, and of the men who wrote them; who they were, the part they played in the world's affairs and above all their attitude towards sport. It is a fascinating enquiry, for it leads us among great books and great men; but apart from its charm it is a necessary one. Without it the earliest English fishing book cannot be understood. But that book has set its seal deep on subsequent books, and the impress remains clear and sharp to the present day. When you read a good modern fishing book such as Lord Grey's Fly Fishing you, all unknowingly it may be, are reading something which can trace a direct descent from the earliest sporting litera- 
ture in Europe. And so, for that reason too, these old books have a very modern application. And that is not all. As the year revolves your thoughts will turn to other pursuits, and you may possibly take down from your shelves the great Peter Beckford's Thoughts on Hunting, or perhaps Peter Hawker's Instructions to Young Sportsmen: though I admit that it is more probable that what you read will be the newest of the new books on either sport. But whichever be the case, you are reading something which is rooted in the past and which would not take the form it does were it not that old writers centuries ago had written books now well nigh forgotten. So, in order that you may never forget that all sport is one, whatever be its manifestation, and that in particular the fishing book which you may buy to-morrow has an old and reputable ancestry, it is worth spending a little time even in a period so remote as the Middle Ages. So let us look at two or three of these early books.

The earliest book on the chase, in France or England, and an instructive and delightful book it is, La Chace dou Serf, dates from the middle of the thirteenth century. Appearing at a time when French prose had not long emerged, it is, as might be expected, written in verse. It may possibly have influenced a later work, for these early writers copied freely from each other, and to understand them it is often necessary to go back to their predecessors. 
The work in question is Le Art de Venerie, par mestre Guyllame Twici, Venour le Roy d'Engletere. William Twici, who wrote in Norman French about 1327, was huntsman to Edward II., and we can still read in the Close Rolls and Exchequer Accounts that he received a wage of $9 \mathrm{~d}$. a day, with $3 \frac{1}{2} \mathrm{~d}$. a day for 'Littel Will' and $\frac{1}{2} \mathrm{~d}$. for the keep of each greyhound and staghound. His book is one of instruction both in practice and in a knowledge of hunting terms, written for an age which esteemed this not the least part of a polite education. The proper way to hunt the hart, the buck, the boar, the hare and the fox, what names to apply to them at different ages, what notes to sound on the horn in order to signify different incidents in the chase of each, these and other matters of diverse and curious learning are to be read in Le Art de Venerie. It is easily accessible in Miss Alice Dryden's invaluable A rt of Hunting, issued a few years ago. It was for long a standard work, was early translated into English, and formed the basis of the treatise on Hunting in the Book of St. Albans, of which more later.

The next book also hails from France: the Livre de la Chasse was written some time between 1387, when the author tells us he began it, and 1391, when he died of apoplexy brought on by a bear hunt on a hot August day. Its author was Gaston III., Comte de Foix and Vicomte de Bearn, who, as well as his book, is 
generally known as Gaston Phoebus. He was lord of two principalities on the slopes of the Pyrenees. He came of a famous house, which gave to the world both that other Gaston de Foix, the young, the gallant, and the unfortunate, who commanded the French at Ravenna when only three and twenty, and was killed at the moment of victory : and also Catherine de Foix, the noble wife of the feeble Jean d'Albret, and the ancestress of Henri IV. Gaston Phoebus is an amazing figure even for the end of the Middle Ages, a time when a ruler's character, good or bad, could develop exactly as it pleased. His life was devoted to fighting, hunting, and the administration of what he was pleased to call justice, bloodthirsty and spectacular. He murdered his only son, yet Froissart, who visited him at his castle of Orthez, picks him out as the model prince. Accompanied by two nobles and forty lances, he crossed Europe from the Pyrenees to Konigsberg, with two objects : to fight the heathen inhabitants of East Prussia, and to hunt reindeer in Sweden. And, be it noted, after fighting the Prussians, he had to help to put down a Bolshevist rising; for thus does history anticipate itself. He hurried back to France to quell the Jacquerie, the ferocious peasant revolt led by Jacques Bonhomme. But there was no end to his adventures, for his character had no half tones, but was everything to excess. When angry, which was often, he 
was a murderous savage*; and yet his book is without question the greatest sporting book in the world. And it is a direct ancestor of English fishing literature; for it was rendered into English by Edward, that Duke of York who fell at Agincourt, and that rendering, the Master of Game, formed the model (as I think I can show) on which Dame Juliana's Treatise was founded.

This Edward Duke of York was Master of Game to Henry IV. of England, his first cousin. His book, the Master of Game, was dedicated to Henry of Monmouth, Prince of Wales, afterwards Henry V. It were out of place in a book on fishing to follow the stormy career of Edward Duke of York. Arch-plotter and arch-fighter, as he is called by his modern editors, $\dagger$ he is known to the world as the gallant Duke of York in Shakespeare's King Henry V., and as the traitor Duke of Aumerle in his King Richard 'II., and it is difficult to say which character fits him the better. He probably began the book in 1405 , when he was lying a prisoner in Pevensey Castle for an act of villainy more atrocious than usual against his royal cousin, and of treachery more outrageous than ordinary against his fellow-conspirators,

* See A Gascon Tragedy (in Excursions in Libraria 1895), by G. H. Powell, for an unflattering portrait of Gaston de Foix.

†The Master of Game. Edited by Wm. A. and F. BaillieGrohman (1904). This sumptuous work contains a good account of Gaston de Foix and Edward Duke of York and their books. 
and completed it in the following year, when he was most undeservedly restored to favour and created Master of Game. But he wrote a great book, the first book on sport written in English, and, as I hope to show, the model and archetype of our immense fishing literature.

By the time of the Duke of York, sporting books had settled into a form which was never afterwards abandoned. They begin with a prologue which sets out the merits of sport compared to other pursuits, treating its subject from the loftiest standpoint, and, in the Middle Ages at any rate, not failing to point out its spiritual as well as its physical advantages. Next follow detailed accounts of the natural history and method of hunting the different animals; then a description of hounds and instruments required for the chase, and at the end there may be an epilogue, modestly commending the book to the public, or perhaps containing rules which all sportsmen should follow, or perhaps repeating and re-emphasising the prologue. This, it will be noticed, is the form of the Compleat Angler, and indeed, with the changes that two and a half centuries bring, of the fishing book of to-day. Izaak Walton did not originate that form, nor indeed did the Treatise : it comes from the Master of Game. So it is necessary to give a short account of the shape and spirit of that great book.

No one leads a happier or more virtuous life than the huntsman, says the prologue. He has 
health of body, and, since he is never idle, health of soul too. The joy of being on a horse, the gallant fellowship of hounds, the exultation of reporting to his lord the harbouring of some noble stag, and of hearing the company say: Lo, here is a great hart and a deer of high meating or pasturing; go we and move him; these are great joys. Every incident of the chase is pleasurable, from the getting up of the hunter early on a clear and bright morning and hearing the song of birds and seeing the dew on twigs and grasses; until he comes home in the evening, weary but triumphant, sups well on the neck of the hart with good wine or ale, and before going to bed takes the cool air of the evening for the great heat that he has. Occupied continually on work which he loves, healthy in mind and body, always in close contact with nature, the hunter lives a joyful and virtuous life and goes straight to Paradise when he dies.

Such is the Prologue to the Master of Game. It holds the very distilled essence of sport, and in addition is exquisite prose. No one can read it and then turn to the Treatise of Fishing with an Angle without seeing the similarity between the two. The Treatise differs only because it deals with a new sport just differentiated. The Master of Game proves that the life of sport is best of all : the Treatise that the fisher's life is best of all lives devoted to sport. That is all. When we read Dame Juliana's epilogue on the 
joys of fishing it is difficult to believe that she did not have the Duke of York's prologue before her, so much do they resemble each other. Both treat their sport from the loftiest standpoint. Both aver that its practice does not benefit man's body alone, but his soul also; for it leads him nearer his God by keeping him free from sin; particularly from idleness, foundation of all evil. Both claim that it brings man into contact with nature at her loveliest. It is difficult to read both, cast as they are in the same mould, imbued with the same spirit and composed from the same standpoint, without coming to the conclusion that Dame Juliana, if she did not consciously copy, at any rate wrote under the influence of Edward Duke of York. All through the book the resemblance continues : in arrangement, in language and in spirit they are identical. And any angler who reads that delightful record of skilled and gallant sportsmanship, the Master of Game, must rejoice that the earliest record of his craft is grounded on so noble a model.

But there is another piece of evidence, which, small in itself, points the same way. The Treatise refers to the Master of Game as the standard work on hunting. Now the Treatise formed part, as will be described, of the Book of St. Albans. This book is a collection of four treatises, all ostensibly by the same author, and one of them is actually on hunting. Now, if the author wanted to quote a work on 
hunting, why did she pass over her own work? Such self-effacement is rare among authors. The inference is, of course, obvious; the portion on fishing is not by the same hand as that on hunting, and merely published under the same cover. But the point I want to make is that the authoress had certainly read the Master of Game and refers to it as the model work on hunting. It is highly probable that it served also as her model for her book on a new craft. However, I shall have a good deal to say about the Book of St. Albans later on in this chapter.

From the Book of St. Albans onwards we part company with French books. There are no good ones until modern times, and these are founded on ours. Henceforth the stream runs on British soil, and it runs deep and full. But the debt which we owe to French literature must not be forgotten, a debt all the greater because it lies in the domain of the spirit. The small amount of fly fishing literature which does exist in France before the nineteenth century is described in Chapter IV.

We now come to the birth of the first book on fly fishing, and to the England of Henry VII. In the year 1486, a year after Bosworth Field, when Henry of Richmond was settling himself into his still shaky throne, and Columbus was trying to get some king to help him to cross the Atlantic, the schoolmaster printer of St. Albans, whose identity is still unknown, printed the Book of St. Albans. It 
treats of Hunting, Hawking and Heraldry, three essentials of a polite education. Apparently it was successful, for ten years later Wynkyn de Worde brought out a second edition, and probably finding that fishing was a popular sport, he completed the book by adding the Treatise of Fishing with an Angle. It thus became a sort of Gentleman's Manual, the kind of book which two centuries later would have been called the 'Compleat' something: the Compleat Gentleman or the Compleat Sportsman; while to-day, in this age of specialisation, it would have been split up into a series of text-books. The authoress was stated to be Dame Julyans Barnes, or Bernes, a mythical lady whose name has now been changed by devout disciples into Dame Juliana Berners, and a romantic though mendacious biography has been compiled for her. But in a fishing book it is not necessary to discuss her existence, for though someone called Dame Julyans Barnes may have been the author of the portion on Hunting, so far as the word 'author' can be applied to a work which is only a compilation produced in an age when literary property did not exist, there is nothing whatever to connect her with the Treatise of Fishing, which was merely added by Wynkyn de Worde to make his Manual more attractive.* And

*Though Dame Juliana Berners has been deposed, no successor has been appointed. Accordingly I shall treat her as author until a better claimant appears : for it is awkward to have to cite an anonymous book. 
assuredly the Treatise became the most attractive element in that attractive book, for it went through sixteen editions or reprints in the hundred years which followed its appearance, either with the Book of St. Albans or separately; and for centuries afterwards angling writers pirated from it, without acknowledgment it need hardly be said. And when open robbery ceased, its influence was no less great and lasting; for it gave the colour and tone to fishing literature, and not even the Compleat Angler itself stamped its mark more deeply on the sport.

Seeing what it is, seeing how mysteriously it arose, and seeing, as will appear, that it is good fishing written in good English, it is worth enquiring whether it is not possible to fix its date, even though the writer must remain unknown. It was printed in 1496, but its date is earlier. There are indications which point to a date as early as the first quarter of the fifteenth century. But in any event it is as early as 1450 . Besides the text printed by Wynkyn de Worde, there is an older manuscript text, included in the great collection of fishing books formed by the late Mr. Alfred Denison, a collection fortunately still intact. This Denison text was edited in 1883 by Satchell, joint author of Bibliotheca Piscatoria, assisted by Professor Skeat, high authorities both. They assign it to a date before 1450. It differs so much from the 
printed text that it cannot be its archetype, and yet resembles it so much that the two cannot be independent translations from another tongue, such as French. Therefore, since there are two collateral texts, they must have had a common English parent, which must at any rate be older than 1450 , and may be much older. Therefore the Treatise is certainly about fifty years older than the date of its appearance in 1496, and possibly older still.

Can any more be said? Can its history be traced still further back? Only by conjecture. Some writers have sought to find the original in some French manuscript, arguing that since all books on sport were born in France, it is probable that the first book on fishing came from there also. It is possible. For myself, however, an English source seems the more probable. That is all that can be said. But whatever the source, the book as we know it must have a long previous history. A work so complete and detailed, showing fly fishing in full swing, with each fish and his habits described, and with flies copied from nature, can hardly have arisen all at once. Indeed Dame Juliana herself disclaims originality. When talking of the carp she says that certain baits are good, 'as I have herde saye of persones credyble and also founde wryten in bokes of credence.' The books of credence are lost or hidden; as to the persons credible, could all the information have been collected and recorded 
from oral tradition? That is possible, but so unlikely that the conclusion appears to be that the Treatise as we know it is drawn from a series of manuscripts now lost or unknown. These books of credence, if English, will probably never be seen : for England has been searched pretty closely in the last thirty or forty years. But if they are French, they may still lie undiscovered in some French abbey. Blakey, writing in 1846, says in his Historical Sketches of the Angling Literature of all Nations, a readable though unreliable work, that a few years earlier a paper had been read to a society of antiquaries at Arras on an old manuscript on fishing, dating from the year 1000, and found among the remains of the valuable library of the abbey of St. Bertin at St. Omer. Since that paper was read much has happened at Arras in Artois. Many have gone there who never heard of it before, and who have gone there for other purposes than to listen to learned disquisitions on a peaceful sport; who have, like Chaucer's squire,

\section{ben somtyme in chevauchée}

In Flandres, in Artoys, and in Picardie.

Many have made that journey and have not returned. If such manuscripts still exist in Arras in Artois, they will be hard to find.

Such is the history, and such are the probable origins, of the Treatise of Fishing with an Angle. It now remains to examine the book itself. 


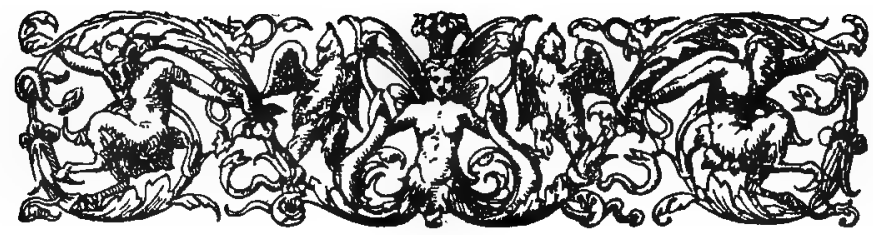

CHAPTER II.

THE TREATISE OF FISHING WITH AN ANGLE

The Angler must intice, not command his reward, and that which is worthy millions to his contentment, another may buy for a groate in the Market.

A Discourse of the Generall Art of Fishing, By Gervase Markham. 1614.

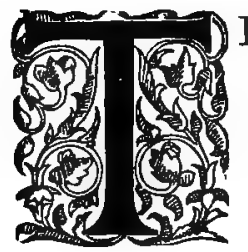

HE Treatise begins with an account of the delights of fishing. Solomon says that a good spirit makes a fair age and a long, and a merry spirit is best gained by good disports and honest games in which a man rejoices without any repentance after. Now, there are four sports of this character, hunting, hawking, fishing and fowling, and of these the best is fishing. It enables a man to eschew all contrarious company and all places of debate where he might have any occasion of melancholy. Perhaps this is the reason why politicians in all ages have found relaxation in fishing. Dame Juliana then enquires into 
the reasons why fishing should be accounted the best sport. She takes hunting first, of which the right noble and full worthy prince, the Duke of York, late called Master of Game, had already described the joys. Hunting she thinks too laborious. The hunter must always run and follow his hounds, travailing and sweating full sore. He blows his horn till his lips blister, and when he thinks it a hare full oft it is a hedgehog. Thus he chases he knows not what. He comes home at even rain-beaten, pricked, his clothes torn, wet shod and miry, some hounds lost, some foot sore. Therefore hunting is not the best sport of the four.

But hawking, too, is laborious and troublous, for the falconer oft loses his hawks, and then is his disport gone. He cries and whistles till he be right evil athirst. His hawks take flights on their own account, and when asked to fly sit and bask. If misfed they get the Frounce, the Rye, the Cray and other sicknesses that cause their downfall. Therefore hawking is not the best sport of the four.

Fowling is a foolish sport, for the fowler speeds not but in winter, and in the hardest and coldest weather. He cannot visit his gins for the cold. Many a gin and many a snare he makes, and many he loses. In the morning he walks in the dew, and, wet-shod and sore a-cold, does not get his dinner till the morrow, or goes to bed before he has well supped, for anything he may get by fowling. Therefore 
hunting, hawking and fowling are so laborious and grievous that none of them induces that merry spirit which causes a long life.

The sport which does this must be fishing, and fishing with rod and line, for other manners of fishing are laborious and grievous, often making folks full wet and cold, which is the cause of great infirmities. But the angler suffers neither cold nor disease nor vexation, save what he causes himself. The most he can lose is a line or a hook, of which he may have plenty of his own making, as this simple treatise shall teach him. The only grievous thing that may happen is that a fish break away after he has taken the hook, or else that he catch nought, which is not grievous. For at least he has his wholesome walk at his ease and a sweet air of the savour of the meadow flowers, that makes him hungry. He hears the melodious harmony of birds; he sees swans, herons, ducks, coots and many other birds with their broods, which is better than noise of hounds or blast of horn or cry of wildfowl. And if the angler take fish, surely then is there no man merrier than he is in his spirit. Thus is it proved that the sport of angling induces: a merry spirit, and therefore to all that are virtuous, gentle and free born Dame Juliana. indites her Treatise, by which they may have the full craft of angling to disport them at their pleasure, to the intent that their age may flourish the more and endure the longer. 
It will be seen how closely this prologue follows the traditional sporting model. A general review of all sports is made, with a conclusion in favour of the one in which the writer is interested. In this the book was followed by other writers, and indeed has set a stamp on angling literature which has lasted to our time. Walton, who took his list of flies from Mascall, who took it from the Treatise, also followed this introduction; for his dialogue is but an expansion of the comparison of the merits of different pursuits, cast into actual conversation. In his first chapter* the Hunter and the Falconer describe the joy of their crafts, and the Fisherman answers and excels them. It is very like the Treatise. And in observations on the joys of nature, and in moral and religious reflexions, the Treatise both looked to the past and pointed a hand to the future: developed by the Compleat Angler, it determined the form of our angling literature, and it is itself rooted deep in the Master of Game.

Having established the rank of the craft, the Treatise describes the angler's tackle. It starts with the rod, which in that day had to be homemade. It was in two parts, a 'staffe' or butt, and a 'croppe' or top. The wood for it must be cut in winter between Michaelmas and

*Of the second and subsequent editions. In the first edition the Traveller is the principal interlocutor: in the second edition he disappears, replaced by the Hunter and the Falconer. 
Candlemas, heated in an oven, straightened by being tied to a straight piece of wood, and thoroughly dried in the smoke. The butt must be of hazel willow or rowan, six* feet long or more, as thick as your arm and evenly tapered; the pith must be burnt out so as to make the butt hollow with an even taper inside, a broad ferrule of iron or brass placed at each end, and at the bottom a spike made to take out, to enable you to get at your top, which was carried inside the hollow butt. The top was in two portions neatly spliced together, the whole as long as the butt into which it fitted; the lower part of green hazel, and the upper a fair shoot of blackthorn, crabtree, medlar or juniper. Bind a double line of six hairs thickness on to the top at the splice, carry it down to the point and there make a loop on which to fasten your line. When you fish you take out your top and place it in the hole at the top of the butt, into which it fits; when you are not fishing put the top inside the butt, and you will have a rod so well disguised that you may walk with it and no one will guess that you are going fishing. It will be light and full nimble to fish with.

The line is to be of horsehair, white and round, the longest you can find. Stain it different colours for different waters, cut off

\footnotetext{
*Denison Text. An Older Form of the Treatyse of Fysshynge wyth an Angle. London. Satchell. 1883. It is obviously the purer text, and I have used it in several places where it differs from the printed text. Unluckily, it is imperfect, and does not contain the section on flies.
} 
the weak ends (most excellent advice, for it prevents the weak ends being accidentally twisted into the line) and twist it on a machine of which a figure is given. When you have twisted enough links to make your line, join them together by a water-knot or a duchess knot, whatever that may be, and cut off the waste ends, but not too short, leaving a straw's breadth. This again is excellent advice, and as useful now for gut as it was four hundred years ago for horsehair.

Hooks are the most subtle and hardest part of your craft. You want a whole armoury of tools, of which a really admirable figure is given. For small hooks use the smallest square-headed steel needles that you can get; for larger ones embroiderers' needles or tailors', or shoemakers' awls, which are specially good for large fish. Heat your needle red hot in a charcoal fire, cool it, make the barb with your knife and sharpen the point. Then heat it again and bend it into the shape of the very excellent figure which is given; test the temper of the point, flatten the shank and file it smooth so that you can lash your line to it, heat it again and plunge it in water; thus will it be hard and strong.

To fasten the hook to the line, take fine red silk, for small hooks single, for large ones doubled, but not twisted. Another excellent piece of advice: the best modern book on dressing salmon flies, Hale's How to Tie 
Salmon Flies, tells you to take the twist out of your doubled tying silk before using it. Take a few close turns of the tying silk round the line; then lay your line on the inside of your hook, and starting at the end of the hook fasten on the line two thirds of the way up to the bend; then turn back the waste end of your line and for the last third of the way lash it on double, and finish off round the shank of the hook with the well-known whip finish and draw tight.

These directions for making tackle have been given at length in order to show their excellence. Not only are they excellent; they are modern. The casual reader, misled by the archaic English in which the Treatise is written, and above all by some of the clumsy plates with which it is embellished, especially the frontispiece and that of the rod, may think that the practical part of the book is worthless. This is quite untrue: the rod, which in the picture looks like an ungainly pole, is really light and flexible: a hollow butt, a springy middle joint of hazel, and a light yet tough top make up something which would throw a fly uncommonly well.*

It is necessary to understand this, if we are to form a picture of the time. The fisherman cannot practise the refinements of his craft unless properly equipped, and, save in one

*This was first pointed out by Mr. R. B. Marston in Walton and the Earlier Fishing Writers. (1894). 
respect, he was so equipped. True, his rod, which must have been between twelve and eighteen feet long, seems large to our thinking. It must not be forgotten, however, that its hollow butt and hazel middle joint made it light for its length. Cotton, too, who fished skilfully enough to satisfy the most critical, used a rod fifteen to eighteen feet long, a single-handed rod too. The fact is that before the reel was invented the long limber rod was essential if you were to kill big fish without being broken, and indeed long rods survived years after the invention of the reel, for as late as the first half of last century Ronalds says that a strong man can use one of fifteen feet. The short rods we now use are a modern invention.

The one exception to the excellence of Dame Juliana's tackle is her line. It must be confessed that she did not fish fine. In fact. very much the contrary. Lines are to be used of varying thicknesses for different fish, starting with a single hair for the minnow, and running up to fifteen hairs for the salmon. The trout is to be fished for with a line of nine hairs, and the great trout with one of twelve. It must be admitted that these are monstrous thick lines. Lawson, writing one hundred and twenty years later, tells you to use a line three hairs thick: and Barker, thirty years later still, says that you can kill the greatest trout that swims on a single hair, if you have sea room, and that a single hair will kill five trout 
to one taken by a line of three hairs twisted. Cotton used double hair, except for a very small fly, when he used it single, and for the mayfly, when he used it treble. With double hair a man who could not kill a trout twenty inches long deserved not the name of angler. Finally, Franck, a contemporary of Barker and Cotton, speaks with wonder and awe of a certain Isaac Owldham, who used to fish salmon with a line of three hairs only next the hook. All these authors, be it remembered, are speaking of fishing with no reel, and to kill a four pound trout on a single hair without a reel, or a twenty pound salmon on three hairs, ${ }^{*}$ is a feat few modern anglers would care to attempt. So we must remember the disadvantages under which early fly fishers suffered when we criticise their clumsy lines. Still, when all allowances are made, it must be admitted that the lines in the Treatise are unnecessarily heavy.

But there is another point we must remember, too, and that is the method of fly fishing which prevailed then and long after. Casting downstream with the wind behind you and using a hair line which though thick was light, it was possible to keep nearly all the line off the water. Early writers insist on this, that your fly must alight before your line, and

*When Duncan Grant killed his big fish in the Aberlour
water of the Spey, after playing it all night, he had thirty
plies of hair next the $f$ y ! And this was at the beginning of
the nineteenth century!
- Scrope. Days and Nights of Salmon-Fishing. 1843. 
as little of it as possible must touch the water. And also some of them give directions enabling you to keep your fly near the top after you have cast, and flies were specially dressed to swim on or near the surface. Therefore, though the line was thick, nearly all of it was in the air, and consequently much less visible to the trout than if it were in the water. The line, too, though it was thick, was made of white and translucent horsehair, and was less conspicuous than might be imagined.

The hooks, if the plate can be taken as a guide, and it probably can, were not large. Measured across the bend they run from about 2 or 3 to 15 on the modern scale, but they are shorter in the shank and thicker in the wire.

So much for the rod, line and hooks : what about flies? The Treatise gives a list of twelve, a famous list, pirated by Mascall from the Treatise, by Walton from Mascall, and from him by numberless lesser writers for hundreds of years. So interesting are flies that they want two chapters to themselves, and are described in Chapters VIII. and IX. It is only necessary here to deal shortly with Dame Juliana's list. Out of her twelve flies, eleven can be identified. That is rather wonderful, but I believe it to be incontestable. The eleven are her first Dun Fly, which is the February Red, dressed with a partridge feather for wing and a brown body, as it is dressed to-day; her second Dun Fly, which is the Olive Dun; 
the Stone Fly; the Red Spinner, which is her fly made of roddyd (i.e. ruddy) wool; and her Yellow Fly, which is the Little Yellow May Dun. The Dun Cut of Dame Juliana is the Yellow Dun, the name having survived until the nineteenth century.* Then her Maure (mulberry coloured) Fly and Tandy (tan coloured) Fly, with a body of tan coloured wool and wings of the lightest mallard, tied back to back, can be nothing but two dressings of the Mayfly in different states. The Wasp Fly, with a black body ribbed with yellow, speaks for itself. The Drake Fly, with its black body and dark mallard wing, is uncommonly like the modern dressing of the Alder. Lastly, the Shell Fly is the Shell Fly of Ronalds, with a dressing very similar, in spite of three and a half centuries. Thus it is possible to identify clearly eleven out of the twelve. The remaining fly is the Black Louper, appearing in May, which seems to have been a hackle fly, and corresponds to our Black Palmer or Coch-yBonddhu, but cannot be identified exactly.

The important thing, however, is not the exact identification of these flies more than four hundred years after they were described, remarkable though that is, but the recognition

*i.e. the Yellow Dun of Ronalds, not to be confused with the other Yellow Dun, his Little Yellow May Dun. See also Practical Fly Fishing by Arundo (John Beever) 1849, p. 18. He describes a fly he calls the Spring Dun, which is the summer dressing of the Olive Dun, and gives Dun Cut as one of its synonyms. Sir Humphry Davy too gives Dun Cut as a synonym of the Yellow Dun. 
that they were copied from nature. That is clear. The Treatise tells you when you take a big fish to open his stomach and see what is therein, and use that; the first mention of autopsy, usually imagined to be the most modern of modern devices. This is not said especially of fly fishing, but it can perfectly well be applied to that. Not only are the flies copied from nature, but they are uncommonly good copies, considering the limited materials then available. And moreover the time of year at which the natural fly appeared has been observed. Altogether, fly fishing has passed its babyhood.

No directions are given either for dressing or for casting the fly. The general fishing maxims can be summed up in a few sentences : keep well off the water and out of sight, keep your shadow, too, off the water, and cast over rising fish. Strike neither too slow nor too quick nor too hard. When you hook a fish do not be in a hurry to land him, but tire him out and drown him. Do not let him come to your line's end straight from you, but keep him under your rod, so that your line may sustain and bear his leaps and plunges with the help of your top and your hand.

This last sentence gives the classic instructions for playing a fish with no reel. You must keep your fish under the curve of your rod, which, being long, light and flexible, takes the strain and relieves the line. If you do not, if 
you let him run to the end of your line, as more than one writer puts it, that is, get your rod and line in one straight line, he will break you to a certainty. Now it is clear that, if a fish runs straight away from you, you must, if you wish to keep a full curve on your rod and use its flexibility to the utmost, carry it back over your shoulder more and more the further the fish is away, so that finally you are in the attitude so commonly figured in old prints, your rod thrown right back over your shoulder, and the butt pointing towards the fish. This position, "shewing the fish the butt,' as it is called, was strangely misunderstood in reelusing days. It was thought that the object of this ungainly attitude was to put the greatest possible strain on a fish, and Francis Francis is at some pains to show that this is not what it does. Nor has he any difficulty in doing so, for so far from putting the greatest you are putting the least strain on the fish, and the greatest on the rod. You are using the rod to its utmost pliability, and indeed making a demand on it which no modern stiff rod could answer. Ronalds, who advocates a flexible rod as long as fifteen feet, puts the matter right. The beginner who has hooked a fish should, he says, get his rod up over his shoulder, and present the butt end to the fish, for thus he can make best use of the rod's pliability. If the reader will think it out, he will see that no better rule can be given than to point the butt 
straight at the fish, for, whatever position he be in, this makes the best use of the elasticity of the rod.

The truth is that playing a fish is no longer the art it was. A heavy fish on fine gut is difficult with the best of modern reels; imagine what it must have been without any. In those days you really had to play your fish, and to tire him out with hand and rod. Now he largely plays himself, and yet he often breaks us.

The trout is in season from March to Michaelmas, and whenever it or the grayling are seen rising, they are to be fished for with an artificial fly, suiting the fly to the month. Elaborate baits are given for the trout and for all other fish, but they are not our business. They were largely copied by Walton, and many are used to this day. The trout is a right dainty fish, and also a right fervent biter. He loves clean gravel and streams.

Fly fishing for salmon was not unknown. When a salmon rises he may be taken with a fly as a trout or grayling; but, adds the author, it is seldom seen.

Directions are given where to fish. In a pond, which is but a prison for fish and where fish are hungry as prisoners, there is no need to be particular, but choose a place of moderate depth. In a river, the best place is where the water is deep and the bottom clean, such as gravel or clay, which is free from mud or weeds. 
Especially choose a whirling water, or where there is good cover for fish, such as a hollow bank or great tree roots or floating weeds. Deep water, waterfalls and weir pools are also recommended; 'and it is good for to angle where as the water restyth by the bank and where the streme rennyth nyghe there by, and is deep and clear by the ground.' As a fisherman reads these words, there must come into his mind many a vision of clear and quiet waters flowing gently under a bank, with a strong stream running near thereby, and noble trout rising in the quiet water.

Advice as to time of day and weather follow. From May till September the early morning from four till eight is best, and from four to eight in the evening next best. A dark lowering day with a cold whistling wind, or with a soft wind, are both good. If at any time of the day the trout or grayling rise, fish for them with a fly, choosing one appropriate to the month. This advice is repeated no less than three times. Weather which is either bright and hot or sultry is unfavourable, and so is a wind with any touch of East in it. West and North winds are good, but the best is the South. Heavy winds, snow, rain, hail, or a thunderstorm are all bad.

The Treatise, which started upon general observations, ends on the same note. It started by describing the perfect sport and ends with a picture of the perfect fisherman. His duty 
towards the sport, towards his neighbour, towards the poor and towards his God is depicted from the loftiest standpoint, and set out in language rarely equalled for dignity and grace. No base action must mar the angler's practice and no base motive enter his heart. He must studiously respect the rights of others, particularly of the poor. The fish are to be protected in all ways possible, and vermin are to be destroyed. The sport is to be followed for its own sake, not from mercenary motives or for material gain, and never to excess; but as a noble recreation, which will bring you solace and health of body. Nor of body alone, for your sport, of necessity a solitary one, gives you an opportunity of serving God devoutly, repeating earnestly your customary prayer. By so doing you will avoid many vices, especially idleness, foundation of all evil. All they who follow these rules shall have the blessing of God and Saint Peter; which he them grant that with his precious blood us bought.

That concludes the Treatise. What impression does it leave? How did a fisherman fish, in this year 1496, when Bosworth Field was a memory but eleven years old, when John Cabot was sailing towards Newfoundland, when Erasmus was about to visit Oxford, when Luther was still a schoolboy, and when Wynkyn de Worde had just succeeded to Caxton at Westminster? How will his equipment, his knowledge, and his practice compare with ours 
at the present day? It is a long time truly since that year 1496, and many things have changed in the interval, sport among them. Gone are the hawker and the fowler, their occupation merged in that of the shooter. Fishing has changed too. Perhaps hunting, especially hunting the hart, has altered the least : for were Gaston de Foix or Edward Duke of York to be present at a meet of the Devon and Somerset staghounds they would find essentials unaltered. And when the harbourer told them of the stag he had harboured, what signs of venery he had noted, and what conclusions he drew as to its size and age, why he and they would talk the same language, though five hundred years did separate them. But what about the fly fisher? How did he fish at the end of the fifteenth century, when the Wars of the Roses were over and the Reformation yet to come?

Success in fishing depends on three factors: the angler's equipment, his knowledge of fish life, and his skill in making use of these in presenting the fly to the fish. From the Treatise we know much about the first two factors, but hardly anything of the third, for we do not know how a fisherman fished. $\mathrm{He}$ was not handicapped by his equipment, if thick lines are excepted, and even this handicap could largely be neutralised by keeping the rod point high and the line off the water. There is nothing wrong with his flies, though it must 
not be forgotten that we do not know what they actually looked like, nor must it be assumed that because a modern dresser could make excellent flies out of the old dressings they were made with equal care over four centuries ago. But after making all allowances, it is safe to assume that his flies, though more coarsely dressed, larger in the wing and thicker in the body than those used now, still were fairly serviceable. The rod, from twelve to eighteen feet long, single-handed, was light and stiff yet springy, and with a following wind or on a still day would cast a hair line with delicacy and enable the fisherman to put his fly accurately and softly over a rising fish. So much for equipment. The fisherman's watercraft also was not wanting. He knew that he must keep out of sight and keep his shadow off the water. He knew that his fly must imitate not only a natural insect but the one which was up at the moment; and that if he had any doubt all he had to do was to open a fish's stomach and see : and it is therefore not too much to say that he was told to use an imitation of the actual fly which fish were taking. He knew where to look for a rising fish. And he knew that whenever fish were rising they would take the artificial if the right one were found; and putting all this advice together we come amazingly near the practice of fishing for individual rising fish with a copy of the fly they were taking. 'From Aprill tyll Septembre ye trough lepyth, thenne 
angle to hym wyth a dubbyd hooke, acordynge to the moneth.' The resemblance, however, must not be pressed too far. To do so would be to make the mistake of reading modern ideas into the loose language of an old writer. And caution is particularly necessary owing to the fact that the Treatise does not say how the fisherman used his fly. We are told nothing of the third factor, presentation. Casting the fly is not mentioned until Lawson wrote, a century and a quarter later. The fly must have been cast, but how we know not. It can only have been cast down wind or in a calm, for the rod and line used could not have cast up wind. The rest is guess work. Whether the fly was thrown up or down stream, whether it was allowed to float with the current or was drawn across or against it, whether it was kept near the surface or allowed to sink, we are not told. But it is not a very extravagant guess to assume that the usual practice was to fish down stream and to draw the fly, keeping it near the top of the water. It is pretty clear, too, that a windy, or at least a breezy, day was chosen, and a cloudy day was thought best; a dark day with either a soft wind or with no wind at all is considered the best of any. These indications point to an art in its infancy, but on the other hand it is not too much to say that the advanced knowledge of fishing lore which the Treatise shows must have carried with it an equal degree of skill in the application of that knowledge to the 
business of catching fish. That is all that can be said. It is dangerous to exaggerate the resemblance to modern times and to attribute to the writer refinements of which she was ignorant. Fly fishing is in its infancy and has a long road to travel before three pounders are caught in still and sunny June on $4 \mathrm{X}$ gut and 000 flies. But it is as great a mistake to overlook the high degree of knowledge which every line of the Treatise shows, and the more it is studied the more profound grows the conviction of its excellence and of the high standard of practice which it presupposes. 


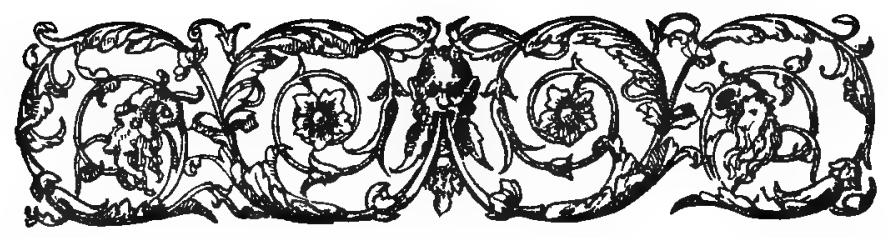

\section{CHAPTER III. \\ FROM THE TREATISE TO THE COMPLEAT ANGLER.}

And in mine opinion I could highly commend your Orchard, if either through it, or hard by it, there should runne a pleasant River with silver streams; you might sit in your Mount, and angle a peckled Trout or sleighty Eele, or some other dainty Fish.

\section{A New Orchard and Garden, By William Lawson. 1618.}

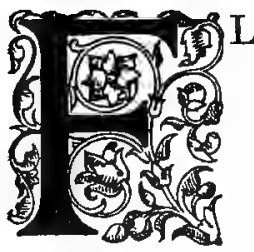

FISHING made no big advance for a century and a half after the publication of the Treatise. That book, the standard work, went through sixteen editions or reprints in the hundred years that followed its appearance. The England of Henry VII. had passed into that of Henry VIII., of Mary and of Elizabeth: Charles I. had lost his head and the Lord Protector ruled, before a school of writers arose who carried the art a long way forward. However, its history is not wholly 
barren in this century and a half. The demand for the Treatise shows that fishing was a popular sport, and fly fishing in particular marked some progress. Its story centres in the names of three writers, Leonard Mascall, William Lawson and Gervase Markham.

A Booke of fishing with Hooke \& Line by Leonard Mascall appeared in 1590, the year which saw the publication of the Faerie Queen, and the year before the production of Love's Labour's Lost, the first play which can with certainty be assigned to Shakespeare. It ran rapidly through four editions. Mascall was a diversified writer and produeed a well known book on grafting fruit trees; he also wrote on trapping vermin, on poultry, hygiene, cattle and horses, and on removing stains from silk and velvet. The Book of Fishing is a mixture of odds and ends of information about fishing and fish preservation collected from many sources. It falls roughly into two parts. The more important deals with fish culture, of which Mascall was a pioneer, and is original and valuable, and of itself gives Mascall a high place. The other part, directly concerned with fishing, is not original, for it is largely copied from the Treatise and other sources, and, moreover, not only is it copied, but there are numerous silly mistakes in the copying. But, for all that, to fishing in general and fly fishing in particular Mascall made a certain contribution. Flies, he says, are to be used on 
the top of the water; the Ruddy Fly in particular, our Red Spinner, is a good fly to angle with aloft on the water, and all flies are to have the foundation of their bodies of cork, which would make them buoyant. This is interesting, for cork bodies are generally thought quite modern. In June, July and August the artificial fly fished at the top of the water is the best lure and also the one most used, which shows that fly fishing was widely practised and that fishing knowledge had advanced. When you fish with the fly for the trout you must strike when he is a foot or more from it, he comes so fast. There speaks the fly fisher, fishing perhaps for small fish. On the other hand the Treatise, dealing chiefly with bait fishing, bids you be not too hasty to smite nor too late, for you must abide till you suppose that the bait is fair in the mouth of the fish and then abide no longer. The true rule was not given till Cotton said that you should strike a small fish quick but wait till a big one had turned his head. All these useful bits of knowledge are, so far as I know, original. Mascall is also the first to describe the double hook, of which he gives a figure.

Mascall is the earliest English writer on fish preservation. He inveighs against fishermen who kill all through the year, including the breeding season, which he puts at from mid March to mid May; it is that which makes fresh fish so dear and rivers so badly stocked. 
Many owners too let their waters without reserving a close time. He gives careful directions about destruction of vermin : the heron, otter, water rat, kingfisher, cormorant, dabchick, coot and osprey are all condemned, and very excellent advice is given about protecting fish spawn. Altogether, the book is a combination of good and bad. Mascall, in such parts as he pirated, is so careless that often he does not trouble to see that what he writes makes sense, but in what appears to be original he is good. He clearly was a good sportsman : the preservation of fish was what chiefly interested him, and he remarks bitterly that there are many that kill fish but few that save and preserve them.

Mascall was the channel through which the Treatise reached Walton. This is proved by the names of the flies. Mascall copied the Treatise's list; but of four flies, either through misreading or intention, he gives names different from those in the Treatise, and in every case Walton gives the same. Thus the fly made of 'roddyd' wool becomes the Ruddy Fly, and the Dun Cut, Maure Fly and Tandy Fly of the Treatise become respectively the Sad Yellow Fly, the More or Moorish Fly and the Tawny Fly in Mascall. In all four cases Walton follows Mascall, not the Treatise. Markham also copied Mascall, not the Treatise, but differs slightly from him, and where he differs Walton follows Mascall, not him. None of the three 
books is mentioned in the long list of writers cited in the Compleat Angler. Walton must have read Mascall; there is no evidence that he read the Treatise.

Fly fishing is not mentioned by John Dennys in his much quoted but still beautiful poem, the Secrets of Angling, published in 1613. This work is some of the best poetry ever written on sport and is one of the finest didactic poems on any subject. Indeed I am not sure that it does not even comply with Swinburne's stern but indisputable canon, that nothing which can possibly be as well said in prose ought ever to be said in verse. However that may be, and there will be difference of opinion both as to the rule and its application, there can be no doubt that the Secrets stands out amongst angling verse. Perhaps this is not saying much, for it must be confessed that many fishing poets are in the same case as the Christian poet Prudentius, of whom it was said that he was altogether a better Christian than poet. Dennys stands in a high class, with Gay, with Sir Henry Wotton, with Doubleday's fine sonnet, with the best of Stoddart, with Andrew Lang and with a few others. His poem, too, is a good description of contemporary methods, and contains the first mention of the whole cane rod, the landing net, and the wicker creel. However, it does not mention fly fishing; but the second edition published about 1620 , as well as some later ones, were edited by William 
Lawson. Beyond the fact that he was certainly a north countryman, probably a Yorkshire man, and wrote on agriculture and gardening, nothing is known of Lawson. But he has a marked place in the history of fly fishing; his notes to Dennys are so entirely original and written in so attractive and individual a style that it is exasperating that he did not write more, or that more is not known about him, more especially as his New Orchard and Garden shows that he possessed a real eye for nature and could write rather charming English. However, we must be grateful for what we have. He recommends a pliant rod, not top-heavy, which is a great fault, and is very particular about his hooks, which he made himself from Spariish and Milan needles, though by that time hooks could be bought and had no longer to be homemade :- The best forme for ready'striking and sure holding and strength, is a strait and somewhat long shank and strait nibed, with a little compasse, not round in any wise, for it neither strikes surly nor readily but is weak as having to great a compas.' He gives an admirable figure of three hooks to illustrate his views. When Dennys expends a stanza in explaining what wind is best Lawson adds this laconic note :-'I finde no difference of windes except too colde or too hot, which is not the .wind but the season.' Altogether a most sensible man; every note of his is vigorous and terse. His fame as a fly fisher rests on a long note to 
Dennys' description of the trout. This fish, says Lawson, gives the most gentlemanly and readiest sport of all, if you fish with an artificial fly, a line twice your rod's length of three hairs' thickness, in open water free from trees on a dark windy afternoon, and if you have learned the cast of the fly. That is the first mention of fly casting. Your fly must imitate the Mayfly, which Lawson thought was bred of a caddis and called the Water Fly, and he gives a picture, the first ever given of an artificial fly. It resembles a house fly on a hook more than anything. The colour of the body must change every month, starting with a dark white, and growing to yellow as the season advances. The body should be of crewel of a colour appropriate to the month, ribbed with black hair, the head of black hair or silk, and the wings of mallard teal or pickled (speckled) hen's wing. 'You must fish in, or hard by, the stream, and have a quick hand and a ready eye and a nimble rod, strike with him or you loose him. If the winde be rough and trouble the crust of the water, hee will take it in the plaine deeps, and then, and there comonly the greatest will arise. When you have hookt him, give him leave, keeping your Line stright, and hold him from rootes and he will tyre himselfe. This is the chiefe pleasure of Angling.' It is difficult to beat that description. He evidently knew a great deal about the habits of fish. 'The Trout lies in the deep, but feeds in the streame, under 
a bush, bray, foame, etc.' He says also that May, June and July are the best months, which alone proves him a fly fisher. In the evening a fly with a short line moved on the crust of the water under trees or bushes is deadly, provided you are well hidden. This, now called dapping or daping, he calls bushing.

One advantage the fisherman enjoys lies in the attractive character of those who have written on the sport. Gervase Markham is an instance. Bred a soldier, and having served in the Low Countries and as captain under Essex in Ireland, he soon abandoned arms for literature, but he brought into his new profession a quality which he may have learnt in his old, an irresistible propensity to loot. He lived by literature, and lived exceedingly well. Few who come across him have a good word to say for him, and truly he is hard to defend, for he is doubly condemned by his contemporaries. The London stationers, tired of his habit of writing or annexing several books on the same subject and selling them under different titles to different houses, combined against him and made him sign an agreement which can still be seen, promising to write no more books on the diseases of horses or cattle. And Ben Jonson called him not of the number of the faithful but a base fellow. Thus he stands convicted both as a man of integrity and as a man of letters. But before Markham is condemned as a man of letters it must be remembered how 
hasty were some of Ben Jonson's judgments, mighty critic though he was; for did he not tell Drummond of Hawthornden that Donne deserved hanging for his lack of numbers and that Shakespeare wanted art? And as to Markham's integrity, let it not be forgotten that he lived in an age not famed for literary scrupulosity, in which the law of copyright was very different from what it is to-day. In his time authors sold their books outright to stationers, who printed and published them, and if Markham robbed at all he robbed them. Far be it from me to defend robbing publishers, but robbing authors of the fruit of their brain as well as of their cash has always been considered the more shameful crime. However, the chief thing to be said in his defence is that he was not, and never pretended to be, a man of letters. He has been called the earliest English hackney writer, and that is a true description, but a truer one would be a writer of text books. Were he alive now, he would give us text books on agriculture, text books on sport, text books on cooking. He started by writing on horsemanship when he was five and twenty, and during his life he occupied himself in turns with poetry both sacred and profane, agriculture, medicine, romances, plays, gardening, hunting, veterinary science, racing, fishing, cockfighting, archery, fowling, hawking, heraldry, household economy and military drill and tactics. He wrote a poem on Sir 
Richard Grenville and the 'Revenge' which without doubt served as Tennyson's model. He is reputed to have imported the first Arab horses, and to have sold one to James I. for $£ 500$. He knew Latin, French, Italian, Spanish and probably Dutch. He possessed a prose style which was fluent, accurate and not disagreeable. If he stole, he stole good matter. He popularised and preserved books, which but for him would be unknown or lost, and he undoubtedly added to the sum of general knowledge of his day. He had a keen eye for the popular taste, tireless industry and an immense circulation, and when the account is cast and the balance struck not only his contemporaries but posterity also is deeply in his debt.

My copy of Markham is a late edition, when it had grown to a fat volume. Its pages are stained and worn, as though thumbed by many a rushlight: and I imagine it the treasured possession of some country house, handed down from father to son, taken out reverently on winter evenings. For it contains everything the country dweller or-his wife wants to know. Care of horse and hound; improvement of barren soil; cost in time and labour of every operation of husbandry; treatment of all kinds of cattle in health and sickness and the growing of every kind of crop; how to bake, brew and cook; household surgery and simple medicine; fishing, shooting with the long bow, bowling, tennis, and the baloone; the dieting of fighting 
cocks and the husbandry of bees; planting of orchards and management of hawks; the ordering of feasts, preserving of wine, and the secrets of divers distillations and perfumes: all these and much more can be learnt from Gervase Markham.

His treatment of fishing is typical. In 1613 he published The English Husbandman, which does not mention fishing. Now, in this same year, appeared Dennys' Secrets of Angling. Markham's quick observation was doubtless caught by this work, for when in the following year he produced the Second Book of the English Husbandman, it contained a Discourse of the Generall Art of Fishing with the Angle or otherwise : and of all the hidden secrets belonging thereunto, a good deal of which is the Secrets pirated into prose. Though the Discourse was published over and over again as Markham's, it has been suggested that Lawson either wrote it or helped to do so. I am confident he did not write it, for his style is very different from that of the sober text book writer Markham. But it is quite possible that he helped. The two men were closely associated in literary work, and Lawson's New Orchard and Garden was repeatedly issued with Markham's treatises under a collective title. Moreover it is obvious that the dressings of flies in the Discourse have been revised by a master hand, and we know that Lawson was a master, while of Markham's skill we know nothing. 
But it is impossible to be certain, and we must take the Discourse as we find it. It is taken partly from Mascall, partly from Dennys and part is original. On the whole it is well put together, and forms a good general treatise. I have no doubt that its compiler was a fisherman, and what is more a fly fisher. Rods, Markham tells us, are to be bought in great variety in nearly every haberdasher's shop. Artificial flies are to be moved upon the waters - the first time the advice to draw your flies appears - and will then be taken greedily. $\mathrm{He}$ repeats Mascall's advice to strike before the trout takes the fly. Chiefly, however, in his dressing of trout flies does he show an advance. He took Mascall's list, but in many cases he changes the dressing, and in most he amplifies it and makes it more accurate. Indeed, if you compare the two lists it is clear what happened : someone, whether Markham or Lawson or another, who was himself a practical fly dresser, used Mascall's list as his basis, went through it fly by fly and rewrote the dressings so as to make them complete and unambiguous, neither of which they originally were. In certain cases, too, he gives dressings different from Mascall's, and altogether polishes them up and gives the finishing touches. Whether that someone was Markham himself or Lawson I cannot say. However all this will be treated at greater length in the chapter on flies. $\mathrm{He}$ is the first writer definitely to recommend you to 
copy natural insects, and he tells you to have natural flies before you when you dress the artificial. His Discourse is included in most of the innumerable republications Markham's works went through.

This however is the sum of the advance of one hundred and fifty years, and truly it is not great. The implements remained much the same. The fisherman used a long rod and no reel, and, if he followed Markham, who recommends five hairs and two threads of silk for trout, a thick line. But under the surface other forces were moving. Lawson, in advance of his time, shows that there existed in the north of England a school of practice higher than anything previously known, a school which was to reach its apex first in Cotton, and two centuries later in Stewart, north countrymen both. But this was below the surface, and its time was not yet. For the rest, fishing was immensely popular. Every haberdasher's shop sold rods, while creels, landing nets, hooks and other tackle could readily be bought, and any bookseller could get you a copy of one of Markham's multitudinous works. The world was ready for the big movement which the next half century was to bring. 


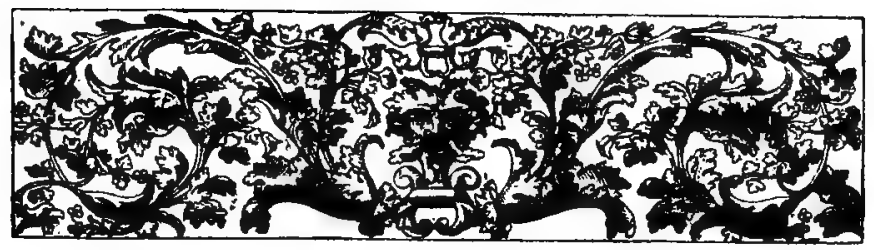

\section{CHAPTER IV.}

\section{EARLY FLY FISHING IN FRANCE.}

La Pêche est un des plus agreables passe-temps qu'on puisse prendre à la Campagne, \& celuy qui renferme le plus de secrets; elle est divertissante, utile \& aisée à exercer, pour peu qu'on ait de patience.

Traitté de toute sorte de Chasse et de Pêche. 1714.

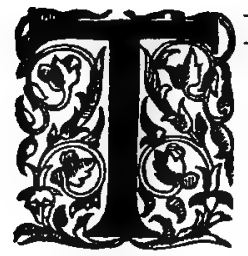

HIS chapter is a digression, for it is necessary to go back, and to collect what little there is of early fly fishing in France. It is very little: I know of no mention of the fly before the eighteenth century, and there are not many books before that which even mention the rod. But do not let it be thought that French literature is barren and uninteresting. It is nothing of the sort; it is rather charming, and would repay more study than it has received. But the rod is much less often mentioned than with us. On the other hand nets and other engines were more highly developed than in England.

It is difficult to say why this difference 
should have arisen. A modern writer has started the ingenious theory that it is due to the fact that in France fresh water fish were treated entirely as food; while England, with her extensive coast and plentiful supply of sea fish, could afford to use her rivers and lakes as sources of sport. But this theory is untenable. Before the days of quick transport and cold storage, fish could not be carried far inland; and our rivers and ponds were important food preserves, whilst sporting rights were worth little. Salmon nets and weirs were extremely valuable, and are mentioned in numberless legal documents; whilst rod fishing for salmon could be had for the asking. Whatever the reason be, the fact remains. The earliest book in England on fly fishing was written during the Wars of the Roses, whilst I know of no French book which mentions the artificial fly earlier than the reign of Queen Anne. It is true that there is one extremely early French book, but unfortunately its connexion with the artificial fly is too slender to stand examination. However, the book is one worth describing.

During the thirteenth century there appeared in France a Latin poem called de Vetula, the Old Woman. It was fobbed off on the world as a work of the Latin poet Ovid, and its manifest inconsistencies, anachronisms and absurdities were bolstered up by a rigmarole of a story that it had been recently found in the poet's tomb. Ovid, it should be said, was a favourite 
mark for forgers of the Middle Ages. It appears to have obtained some credence, for it was printed several times, the last as late as the second half of the seventeenth century; but modern scholarship had no difficulty in demolishing it. Its authorship has now been traced. It is the work of one Richard de Fournival, Chancellor of the Cathedral of Amiens and author of poems which won some estimation in their day. A French version of the Vetula was produced in the fourteenth century by Jean Lefèvre, Procureur au Parlement in the reign of Charles V. of France. This work, called La Vieille, written in rhyming couplets, is a jumble of medieval reflections on life, medieval manners and medieval amusements, a symbol of that strange epoch in the mind of man. But it contains something of value. Against a background which is half childish, half superstitious, and wholly pornographic, there are good descriptions of contemporary pursuits and customs. Music, chess, games and sport are described, fishing included. There is an excellent account of current methods of fishing; spears, nets and eel baskets are depicted: trout, carp, pike, chub, barbel, bream and roach are mentioned and so are lines, floats, plummets and hooks : and there occur the following lines. The spurious Ovid is speaking, as he speaks throughout :

D'autres engins assez avoie,

Par lesquelz decevoir povoie 
Autres poissons es éaues douches, A morceaulx de vers ou de mouches.

It is tempting, but would be wrong, to think that the last line refers to artificial flies. The pieces of fly with which Ovid baited his " engines" must I am afraid have been natural flies, for besides the fact that this is the obvious meaning, he goes on to say that a fish trap of osier was one of these engines, whilst the only equipment mentioned which could possibly be used for fly fishing is a hand line, and this is said to be leaded and with a cork float, and therefore not precisely adapted for throwing a fly.*

There is a long gap after Jean Lefèvre, a gap from the reign of Charles $V$. to that of Louis XIV., and even then the fly is not mentioned. It is true that a famous book had appeared in the interval, for Charles Estienne had produced his Maison Rustique at the middle of the sixteenth century, a remarkable work which all Europe read for hundreds of years, and out of which William Cobbett nearly three centuries later taught his children farming and field sports. But it does not mention the rod. The first book which does is Les Ruses Innocentes, which, published in 1660, went through four editions before the end of the century. Its author was Frère François Fortin, Religieux,

\footnotetext{
* The book has been printed: La Vieille, ou les Dernières Amours d'Ovide. Edited by $\mathbf{M}$. Cocheris. Paris 1861. M. Cocheris' Introduction is a model of bibliographical and scholarly information.
} 
de Grammont, dit le Solitaire Inventif. It is a most practical manual on fowling and snaring generally, chiefly remarkable for its really, admirable illustrations, which are both well drawn and well reproduced. And there is a section on fishing, which makes it quite certain that the Inventive Solitary was a born angler; for he says that all his elaborate rules are useless, unless you know how to time your strike rightly. It is true that his book shows distinct traces of the Treatise, or possibly of Mascall, notably in the description of the rod, but in spite of that it is a work of high originality. It deserves more attention that it has received, and luckily it is still easy to get. It gives the first illustration I know of an eyed hook and of the triangular landing net, now, so common, of which the author claims to be the inventor. Of its sixteen fishing plates, most of them no doubt of nets, are three of rods, hooks and lines. The fly is not mentioned. The two fish which chiefly interested the Inventive Solitary were the carp and the pike. He made his rod of two pieces, a hollow butt of holly or hornbeam and a top of whalebone, and when carp ran large he used a forerunner of the reel. He took a slip of wood four inches long, with a notch at each end, and passed his line, just below the point of his rod, through one notch. Then he wound some yards of spare line round the slip and passed the line through the lower notch. A big carp, when hooked pulled the line 
off the notch, when it unwound itself off the slip, and thus he played himself. This invention is not original, for the principle was used all the world over for a fixed line or hand line, and $I$ think $I$ have seen it mentioned in pre-reel days, as a means of holding slack line in your left hand; but I know of no one who used it as did Frère François Fortin, fixed to the line itself, and working automatically.

Nearly fifty years more had to pass, and Louis XIV. was not far from the end of his long reign, before the artificial fly appeared. In England the Treatise was two hundred years old, Lawson, Venables and Cotton had equipped fly fishing for its long journey, the reel had been invented and modern times are near, before there is any French book mentioning fly fishing, of which I can find any trace. The earliest I know is the Traitté de toute sorte de Chasse et de Pêche printed at Amsterdam in 1714. It is I believe a reprint of Louis Liger's A musemens de la Campagne, 1709. I have not seen this edition of this well known book, but I have seen later ones, and these, as well as the Traitté, I believe to be identical with the first edition.

The Traitté was largely pirated from the Ruses Innocentes, whose admirable illustrations were stolen wholesale. But it has something quite new, for it contains a detailed description of five artificial flies. The dressings are by no means bad and, as will be seen 
in Chapter IX., some can pretty certainly be attributed to natural insects. But more interesting still is the question where they came from. The writer cannot have originated them, for he clearly was writing at second hand. They were not copied from the list in the Treatise, or from any other book I know of. I suspect they came from some French source which I have missed.

No directions are given either for making or casting the fly; and the method of its use is stated only in the vaguest generalities. It is claimed, says the Traitté, that with these flies trout can be fished for successfully with hook and line; and that the fish, attracted by these different colours according to the different seasons, is easily beguiled. And it concludes, 'la proye merite qu'on éprouve ces secrets,' which shows that the writer had no personal experience of the fly.

That concludes all that I know of fly fishing in France before modern times. It is a long way behind England; for Frère François Fortin was a contemporary of Walton, while Liger came half way between Chetham and Bowlker; and, in either case, we move into a different world when we reach England. We must now go back and return thither, to describe a marvellous age. 


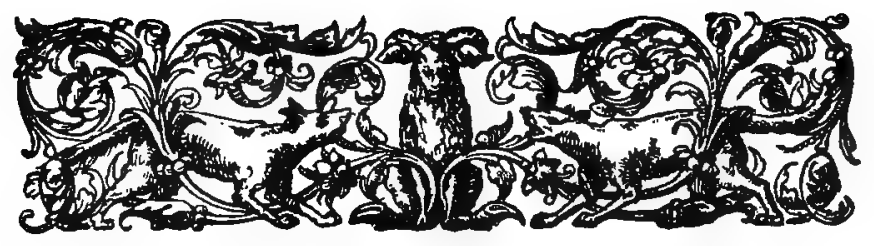

\section{CHAPTER V.}

CHARLES COTTON AND HIS CONTEMPORARIES.

To fish fine and far off is the first and principal Rule for Trout Angling.

The Compleat Angler, By Charles Cotton. 1676.

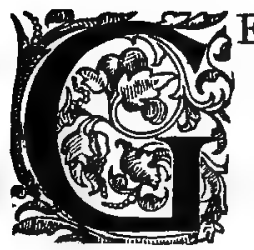

ERVASE MARKHAM closes the first epoch in the history of fly fishing. The second opens with Barker in 1651 and ends at or shortly after Cotton's book in 1676. In this period, exactly a quarter of a century, five writers wrote: Barker, Walton, Franck, Venables and Cotton. All five resembled each other in being practical fishermen, but otherwise were as different as men could possibly be. They approached their task from different points of view and with widely different temperaments and equipments.

Indeed this company of five, who had so deep an influence on the history of fly fishing, are the most diversified crew who ever embarked on the same boat: you could hardly imagine a collection of such opposites; had they all met 
together, which thank heaven they never did, there is no subject on which they could have agreed except fishing, and there would have been broken heads over that. Let us see who they were.

First of all there is Captain Richard Franck, ${ }^{*}$ Cromwellian trooper and Independent, fisherman and religious mystic, possessor of the most turgid and pedantic style with which mortal was ever afflicted. Sir Walter Scott, who brought out an edition of his book, says that his only equal in the rage of fine writing is Sir Thomas Urquhart, but as I have never read that famous translator of Rabelais, I give the palm to Franck, who is unsurpassable. The style of the book may be judged from its title: Northern Memoirs, Calculated for the Meridian of Scotland. Wherein most or all of the Cities, Citadels, Seaports, Castles, Forts, Fortresses, Rivers and Rivulets are compendiously described. Together with choice Collections of Various Discoveries, Remarkable Observations, Theological Notions, Political Axioms, National Intrigues, Polemick Inferences, Contemplations, Speculations and several curious and industrious Inspections, lineally drawn from Antiquaries, and other noted and intelligible Persons of Honour and Eminency. To which is added, The Contemplative and Practical Angler by way of Diver-

*Franck's book was not actually published till 1694, but it was written in 1658 to which date it belongs. 
sion. With a Narrative of that dextrous and mysterious Art experimented in England, and perfected in more remote and solitary Parts of Scotland. By way of Dialogue. Writ in the year 1658, but not till now made publick, by Richard Franck, Philanthropus.-Plures necat Gula quam Gladius.

After this remarkable title the book starts with eleven* Prefaces, Dedications, Recommendatory Poems and what not; before you reach the preface proper you must wade through addresses to my Worthy and Honoured Friend, Mr. J. W. Merchant in London: to the Virtuosos of the Rod in Great Britain's Metropolis the famous City of London : to the Academicks in Cambridg, the place of my Nativity : and to the Gentlemen Piscatorians inhabiting in or near the sweet Situations of Nottingham, North of Trent. After the Preface you must read or skip six poems, from friends to the author or from the author to friends, before you finally reach the book itself. When there, you will have a good laugh, but you will not, I think, read far.

But in spite of his abominable style, Franck was a right good fisher. Not a doubt of it. Through all the obscurities and irritations of his writing, this fact shines like the sun

* It may be mentioned that The Faerie Queen had no fewer than four and twenty such Dedications. But as seventeen of these were sonnets by Spenser himself and six more poems by his friends, of whom Raleigh was one, the world has not found occasion to grumble at their number. Franck sins in quality rather than quantity. 
through fog. He is chiefly a salmon fisher, for he is the first who wrote from experience; and as he travelled in Scotland from the Border to Sutherland and back, he naturally had plenty of that. Unfortunately, words attracted him more than things, and bombastic reflections more than observation and description : fishing is overlaid with a worthless mass of moral disquisition, just as any account of the state of Scotland in 1658, the year of Cromwell's death, which might be of great interest and value, is sacrificed to a turgidity which is often hardly intelligible. Still, something of fishing value can be recovered, and it is all to the increase of Franck's reputation.

Franck is known chiefly for his attack on Walton, whom he calls a ' scribling putationer,' a 'mudler,' ' deficient in Practicks, and indigent in the lineal and plain Tracts of Experience, who stuffs his Book with Morals from Dubravius and others, not giving us one Precedent of his own practical Experiments, except otherwise where he prefers the Trencher before the Troling-Rod: who lays the stress of his arguments upon other Men's Observations, wherewith he stuffs the undigested Octavo.' Sir Walter Scott comments drily that any reader must wish that Walton, with his eye for nature and his simple Arcadian style, had made the journey instead of Franck.

Next to him comes Thomas Barker, a Shropshire man, but living in Henry the Seventh's 
gifts, next door to the Gate-house in Westminster. A Cromwellian too is Barker, but of a different stamp, a cook and not a soldier, employed, at the Lord Protector's charge, in cooking for foreign ambassadors who come to London. $\mathrm{He}$ asks our pardon for not writing 'Scholler like,' but he can readily be forgiven, for he produced a wholly excellent book, copied by Walton for fly fishing and fly dressing, the first which advises fishing fine for trout, and the first which mentions the reel. The book is full of amusing turns and phrases, and as he goes along Barker pauses from time to time and sums up his subject in verse : verse which never fails to dwell on the supreme importance of cookery. But he is also full of good fishing knowledge, as we shall see. He tells you, too, that you can buy the best tackle from Oliver Fletcher at the West end of St. Paul's at the sign of the Three Trouts, the best hooks from Charles Kirby (first mention of a famous house) in Shoe Lane, Harp Alley, Mill Yard, and the best rods from John Hobs at the sign of the George behind the Mews by Charing Cross. Every fisherman should read Barker.

The next is another Cromwellian, and a distinguished one too. Colonel Robert Venables had a long and honourable military career, and rose to a high position in the Parliamentary army. He commanded a regiment in Ireland, where he found time to fish as well as to fight. But Cromwell took him away from his fishing 
and gave him command of the expedition against the Spaniards in the West Indies, which though unsuccessful resulted in the adding of Jamaica to our growing empire. A quarrelsome man was Robert Venables, and it was his quarrels with Admiral Penn which caused the expedition to miscarry. Cromwell, who forgave not failure, clapped both general and admiral into the Tower, but Venables was pardoned, though deprived of his general's commission. At the Restoration he followed Monck, who made him governor of Chester. But Charles II. passed him over, and it is probably to this fact that the world owes a first-rate fishing book. Walton, though a stranger to Venables, wrote an introductory letter to it, full of delicate flattery.

So far three of the five are Cromwellians : the other two are royalists, and they, you will observe, keep slightly to themselves, not very sure of the company into which chance has thrown them. It is superfluous to say much about Izaak Walton and the Compleat Angler. Possibly no single volume except the Bible is so well known by name, and few are more widely esteemed. True, it contains nothing original on fly fishing, but it is not as a writer on fly fishing or even on fishing generally that Walton is read, for he is an idyllist, a moralist, an observer of nature and a master of a prose style which lives because it is individual. The book is of immense importance in a history of fishing, 
both for its qualities and for its influence. A historian must always regard a work of this character from two points of view, for he must assess the value of the book itself and also the effect it had on subsequent writers, and it may be that he will reach different conclusions in the two cases. So it is with Walton. His Compleat Angler itself it is difficult to praise too highly; but a critical judgment of its influence is a much more complex matter. Walton stands high as a writer, and possibly would stand higher were it not for the laudation to which he has been subjected. He has suffered sadly at the hands of his admirers and of his disciples : his admirers have indulged in unbalanced and indeed intemperate panegyric, which has detracted from his real merit: whilst his disciples have either assiduously copied his weaknesses, or, if they have attempted his excellencies, have only succeeded in producing a caricature. His book has been an obsession to subsequent writers, which has lasted to the present day, and has been an influence by no means entirely for good. For this he is not to blame : but no one who has waded through the many books in dialogue form which strew the two hundred years following him-books in which the dialogue, measured by that in the Compleat Angler, is as a dull and lifeless canal running between straight banks compared with the winding reaches of some shining river-but must have wished irreverently that the master had chosen 
to cast his thoughts in some other mould than the dialogue. For assuredly dialogue is at once the most difficult of all literary forms, and also the most dangerous, for its apparent simplicity lures the unskilled to his irretrievable disaster. Charles Lamb was right, as he usually is in literary judgments, when he said that Walton's book is the only treatise written in dialogue which is worth a halfpenny, for in him everything is alive, whereas in others the interlocutors are merely abstract arguments personified. And no one who has sighed over the manner in which countless writers have used Walton's name as a meaningless tag or as a peg on which to hang dull disquisitions or borrowed reflections, or have felt it necessary to present their experiences in a shape which though suitable to Walton in the seventeenth century is utterly inappropriate to another writer in another age, but must have impiously wished that he had possessed a style less individual and a point of view less dangerous to copy. This much, at any rate, is certain, that many writers on fishing would have produced better books if they had not tried to copy him, but had written in their own everyday style. Indeed it is not too much to say, though it sounds blasphemy, that the more a book refers to Walton, the worse book it is. Walton is thereby most unjustly discredited, and his name gets associated with sham archaism, tiresome periphrasis, and irrelevant sentiment. If there are any who 
feel this, and I know there are some, will they take a word of advice from one who has travelled the same road? Let them go back to the Compleat Angler itself, or to one of the Lives, that of Sir Henry Wotton for choice, and they will find that they read it with delight and refreshment. Walton is not one of the great English prose writers, but he is one of the most pleasing. The charm of his style lies in the revelation which it gives of the man. Behind the printed page there always stands Walton himself, shrewd and critical, but also tolerant and kindly. As we read he seems to be watching us with wise and steady eyes, to fathom our wishes before we know them ourselves, and to instil into our minds a harmony for which we have been searching unconsciously. No one has better adapted style to matter, or has known better how to show what is best and deepest in his subject, even when dealing with what appears transitory or trivial. For him love of fishing was woven inextricably with love of books and love of English country life. Every fisherman is deeply in his debt, for there are certain aspects of fishing difficult to express which no one has shown better than he. $\mathrm{He}$ himself owes a debt, it is true, to the Treatise, from which or from a source common to both he took both his presentation of the subject and his mental attitude towards it. But to admit this is no disparagement: he assimilated its spirit and remoulded it, he handed on more 
than he had received, and he tended and kept alive a flame which otherwise might have flickered out.

Charles Cotton, a Royalist too, devoted friend and spiritual son of Izaak Walton, wrote what is perhaps all round the best book on fly fishing ever written. The affectionate friendship between these two men has always surprised those who do not know the binding force of a common sport: Walton, the retired tradesman, the friend and biographer of good and pious men, and Cotton, the dissolute aristocrat, the spendthrift courtier, writer of obscene poetry. But there was an affectionate intimacy between them, and Walton visited Cotton and fished his beautiful Dove. Cotton writes like a man of the world and a man of letters. His prose is pleasant and clear, and though he cannot handle dialogue as Walton and there are traces of that incipient woodenness of which later years were to show so many examples, still the book can be read for itself for the pleasure of its good English. Cotton, Barker and Venables between them, Cotton more especially, place fly fishing on a much higher level than anything before them. They all contributed, and none of them can be spared : and it is worth spending some time on seeing what they did, and where the sport stood when they had done with it.

There are four great landmarks in fly fishing. The first is imitation, the copying of the colour 
and shape of the natural insect. The second is presentation, when action as well as colour and shape is copied, and the fly is cast in such a manner as to come over the fish in the same way as the natural insect does. The third, the practice of casting over individual rising fish, is presentation also, to a higher degree. And the fourth is both imitation and presentation in their highest forms; the copying of shape and colour, the copying of motion, and individual fishing, all combined in the use of the floating fly.

The first landmark occurs at the beginning of things. All flies described in the Treatise are copied from nature. The second and third, upstream fishing and fishing for individual fish, appear among Cotton's contemporaries. The last, the dry fly, was not to come for nearly two centuries.

Venables is the first writer to mention upstream fishing. He discusses the merits of up or down in words which might have been written yesterday. The upstream fisher maintains that he is not seen by the fish, and that if you fish down stream you and your rod and line are all visible. But the downstream man retorts that you obviate this by using a long line. Let it be noted that at this early date the two schools are differentiated as they are differentiated today: those who use a long line down stream and those who use a short line up. Further, says Venables, upstream fishing in- 
volves heavy wading, means covering less water, and most important of all, tends to make you line your fish. Indeed, he says, it must; for either your line falls directly on the fish, or it comes over him before the fly. Venables, summing up the argument, decides in favour of upstream in small brooks, but downstream in big rivers, chiefly owing to the disagreeables of wading, in his time practised without waders. The point to notice however is not his actual decision, but the fact that in the seventeenth century, nearly two centuries before Stewart, upstream fishing is fully established.

So much for the second landmark, upstream fishing. The third, fishing for individual fish, is implicit in fly fishing from the beginning, and must have been practised, but is first mentioned in Chetham's Anglers Vade Mecum. 1681, a good treatise, though largely pirated. He says that when you see a trout rise, you should cast the fly behind him and draw it. gently over him, and then if your fly is of the right colour and you scare him not, he's your own. Not very scientific, but still individual fishing.

In Cotton's day trout were fished for with either a single or doublehanded rod. Both were long, the single rod running up to eighteen feet and the double to twenty-one. Rods were spliced, not jointed. Cotton praises specially Yorkshire rods, with butts of fir, 
made of six, eight, ten or twelve pieces spliced together, tapering like a switch and playing with a true bent down to the hand. Hazel was however the favourite material, though some used cane with a hazel top; whalebone was generally used for the actual point.* Venables' favourite top was four feet of hazel, two feet of blackthorn or crabtree, finished off with whalebone. The rod tapered evenly from butt to point. The common phrase to express this is the curious one 'rush grown,' that is tapered like a rush, or as Dennys says, 'In shape and beautie like the Belgicke reed;' nearly every author of Cotton's date uses the expression. Home-made rods had largely gone out. The line, of twisted horsehair or of hair and silk mixed, was tapered from as many as twelve or even twenty hairs down to a casting line which was one, two or at most three hairs thick. Lines were made specially heavy for fly fishing, as they were easy to cast. Plain horsehair was commoner for the line than hair and silk mixed. Venables dislikes the mixture and subsequent experience proves him right. Hair and silk mix badly, for wetting affects them differently, and the strain comes all on one or all on the other. For the Mayfly Cotton used a casting line of three hairs twisted, for ordinary fishing double hair twisted, and single hair for very small flies. Double hair untwisted he thinks stronger than twisted, but it has the disadvan-

*Spey salmon rods are still made with a tip of whalebone. 
tage that unless the lengths are evenly matched all the play is on one hair, and also the open hairs are apt to entangle your hook, especially in rough water. Single hair is generally too fine, but never use more than double, for he who cannot kill a trout twenty inches long with it deserves not the name of angler. Barker, on the other hand, says that you can kill the greatest trout that swims on single hair, if you have sea-room, and that single hair will kill five for one killed by three hairs twisted. Venables liked a casting line of Lute or Viol string, but it must be changed often as it quickly rots. Perhaps it was he who taught this secret to a great man. On 18 March $1667 \mathrm{Mr}$. Samuel Pepys writes in his diary: "This day $\mathrm{Mr}$. Caesar told me a pretty experiment of his angling with a minikin, a gutt-string varnished over, which keeps it from swelling, and is beyond any hair for strength and smallness. The secret I like mightily.' Pepys' enthusiasm opens vision. What a fishing book he might have written; did he ever fish with Walton, or buy flies from Barker, at Henry the Seventh's gifts next door to the Gatehouse at Westminster? Did he ever spend a rollicking night with Cotton, drinking and singing and talking of fishing and women? Wonderful man, wrote Byron of Scott, how I should like to get drunk with him! A night with Pepys and Cotton would have been well worth a headache.

About this time a substitute called Indian 
Grass or Indian Weed began to be used instead of hair for the casting line proper. The first mention $I$ know is in an advertisement at the beginning of the second edition of Chetham (1700) : At the Sign of the Fish in Black Horse Alley near Fleet Bridge liveth Will Brown who maketh all sorts of Fishing-Rods and selleth all sorts of Fishing Tackle: also Charles Kirby's Hooks, with Worms Gentles and Flys : and also the East India Weed, which is the only thing for Trout Carp and Bottom Fishing. It must then have been comparatively new, for the advertisement goes on to say that it is brittle and must be soaked in water for half an hour before use; it then proves strong and fine and more invisible than hair or silk. It is frequently mentioned through the eighteenth century until superseded by gut. I have never been able to find out what it was. * One fly only was used. The reel was not used in trout fishing. It is first mentioned by Barker in $\mathbf{1 6 5 1}$ for trolling, and by Walton in $\mathbf{1 6 5 5}$ for salmon. Barker gives a figure of it, incomprehensible except that it fastened with a spring clip, but luckily there is a picture of it in Venables' frontispiece. It appears to have been an ordinary barrel winder, without check. Barker used to have twenty-six yards of line on his reel for salmon fishing and he carried a gaff and he had a parchment fly book also. The trout fisher's basket was exactly like ours.

The greatest attention imaginable was paid 
to the fly, which was invariably copied from nature. Markham tells the fisherman to have natural flies in front of him, and to copy their shape and colour. In fact, actual imitation of the living insect was just as much a commonplace in the seventeenth century as it is now in the twentieth, for it is recommended not only in the great books, but even in trivial treatises. Peacham's Compleat Gentleman (1634), for example, which contains a few pages of unenterprising generalities on fishing, yet has this: 'For the making of these flyes the best way is to take the naturall flye, and make one so like it that you may have sport: for you must observe what flyes haunt the water for seasons of the yeare, and to make their like with Cottons, Woole, Silke, or feathers to resemble the like.' Cotton gives the dressings of sixty-five, all original dressings, and Barker and Venables, though they describe general flies, base their case on imitation. Chetham gives twenty, nearly all modern names. The fly on the water was always used when it could be ascertained. You are recommended to look on the bushes, or to examine a trout's stomach. Chetham tells you to use a microscope to examine the flies you find in it, which is wonderfully like to-day. Particular flies were recognised as suitable for particular districts. South country flies then as now were larger and fatter than those of the north, which were dressed slim, with little hackle and the body not carried far down the 
hook, and each were recognised as useless outside their own area. Cotton hung a fat-bodied London fly in his parlour window to laugh at, and on the other hand admits that his slender north country flies proved little use to a London friend. Different flies were used too for night and day. Barker tells a matchless story of fishing from sundown till six in the morning to provide trout for a dinner his patron, Admiral Lord Montague, was giving, and how he caught a mighty dish on three flies, helped, it must be admitted, by lobworms, a white fly, a red fly and a black one, 'the white flye for darkness, the red flye in medio and the black flye for lightnese.' Barker, by the way, calls them palmers, but they had wings, as the dressing shows. When told that the fish were wanted, Barker 'went to the door to see how the wanes of the aire were like to prove,' and returned answer that he doubted not, God willing, but to be provided at the time appointed. Having caught his trout, he tells with gusto how he cooked them: trouts in broth, four dishes of calvored trouts, whatever they may be, marionated trouts, broiled fried stewed and roast trouts, trout pies hot and cold and so on, over a dozen dishes. One would like to have been at that dinner, and one would like to have seen the packed basket which Barker brought home that summer morning. Venables says that flies dressed on double hooks set at an angle of a quarter of a circle were used for tender 
mouthed fish such as grilse or grayling. There is nothing new in the world, for double hooked flies are usually supposed to have come in at the end of the nineteenth century. Venables expressly says that he means hooks with points at $90^{\circ}$ and not opposite each other, such as had recently come in for trolling. This double hook is very old, for it is figured in Mascall.

The two, or rather three, schools of practice which have always divided fly dressers were already distinguished. Granted that you should copy nature, you can copy her in varying degrees. You may have special artificials, such as the Grannom, the Alder, the Iron Blue, the Mayfly and many others, which imitate one species only and nothing else. Or you may, have general flies, imitating a group of species, such as the Ginger Quill, which imitates a Light Olive or a Pale Watery; or such as the Hares Ear Sedge, which is a fair copy of several sorts of sedges; or the Partridge and Orange, which imitates both the February Red and the nymph of the Blue Winged Olive. Lastly, there are fancy flies, which imitate not a species nor a genus nor a group, but fly life generally; such as the Wickham, the Red Tag, or Stewart's three Spiders. It is rather remarkable that specific imitation, the most highly developed, comes first in history. All flies in the Treatise seem to be exact copies, and it is not till Cotton's time that general and fancy flies appear. Cotton himself, however, 
believed chiefly in exact imitation. His flies are copied from nature, though he did not reach the point of fashioning the wings of duns, which are upright, different from those of sedges or the stonefly, which are flat. But he had general flies, too, such as the hackle and silver twist, which he got up early on the second morning to dress. Chiefly, however, he relied on exact imitation: he dressed them larger or smaller, lighter or darker, according to weather and water, but always they represent a natural insect. His contemporaries, however, used general or fancy flies more than he did. A light coloured fly for a clear day, a red or orange fly for a thick water, a dark fly for dark weather, a black or brown fly for a whitish water, says Venables. Barker goes further, and gives five general flies for use all the year, besides individual flies, such as the Mayfly and Hawthorn fly, which he copied. So here for the first time appears the real division, between those who copy the fly and those who attune themselves to weather and water.

All Cotton's sixty-five flies have names, some of which have survived, but the most interesting list is that given by Chetham in an appendix. In the body of his work he merely pirates Cotton, but in the appendix he gives a quite different list, stated to be used by a good angler. The dressings are wonderfully modern, and so are the names also; starling wing appears for the first time. Cotton gives the 
ever useful hint that when you cannot see what the fish are taking, you should try a small hackle. Venables noticed for the first time that trout usually do not come 'on' a fly until it is fairly plentiful, and that they take it best when it is just going off, when they will often refuse other flies even if on the water. $\mathrm{He}$ also noticed that occasionally they changed from one fly to another two or three times a day. Cotton's dressings are good. It is difficult to know what his flies looked like, for the same dressings produce different results in different hands, and it is easy to exaggerate his excellence. But he insists on a slender body carried not too far down the hook, and of this he makes a great point. The thick bodied London fly he condemns utterly. Chetham's dressings, however, are far the best of any of his contemporaries.

Concealment was got not by kneeling or crawling, as we do, but by standing well off the bank, and throwing a long line, fishing, as Cotton said, fine and far off; and they certainly did throw much longer lines than the absence of a reel might make one suppose. With their long whippy rods and light horsehair lines, casting against the wind was next to impossible. It was not practised till long after the seventeenth century. The fisherman manœuvred to get the wind behind him. The thickness of the cast, and even double hair was thick for clear Derbyshire streams and cunning 
Derbyshire trout, was got over by keeping the line off the water. Every writer treats this as the one essential to correct casting. Be sure that your fly fall first on the water, if the line fall first it scareth the fish, therefore draw it back and cast again, says Venables. All say the same. Now to do this a light wind behind you was necessary : in a calm it is possible, but harder : in a head wind the line hits the water first or it is blown back: with a gale behind, the line must be drowned or it is blown off the water.

We can now, figure their fishing, and in expert hands it was skilful and effective. In upstream fishing where practised the fisherman cast straight above him with a short line. But downstream fishing was more common, a good deal of it, no doubt, of the crude type which still survives, a methodical and unimaginative searching of the water such as still obtains in salmon fishing. Probably this would have filled a basket on most waters. But on shy rivers or in skilled hands the system permitted of a more delicate and deadly practice : the cast was made with the rod point well up, the fly with a link or two of the finest part of the cast alone fell on the water, then the hand was lowered and the fly was floated lightly and with little drag over the fish; with a long slender rod, a delicate hand and a line light and at the same time with a bulk on which the wind could act, the fisherman, standing right back in the 
meadow and fishing across and down, could drift his fly over a rising trout in a way that formed the nearest approach to the floating fly before the nineteenth century. This is the way in which, two centuries later, Stewart says that Tweedside adepts killed heavy baskets. They cast frequently and allowed their flies to float only a few yards, and then cast again before they began to drag. Thus do the great masters talk to each other across the centuries. Other methods, however, more crude and primitive were in use. The fly was cast across or down, and drawn over the fish as in loch fishing. You are told to keep the fly in perpetual motion. As a general rule, the fly was fished on the top of the water. Barker specially dressed his flies so that they floated near the top, as he tells us in one of his engaging rhymes :

Once more, my good brother, Ile speak in thy eare,

Hogs, red Cows, \& Bears wooll, to float best appear,

And so doth your fur, if rightly it fall,

But alwayes remember, make two and make all.

The meaning of the cryptic last line is that Barker considered that if you knew how to dress two flies you knew all, what he calls a Palmer (though it had wings) and a Mayfly. Venables tells the fisherman to try the trout first on the top, and if they will not take there, to try below the surface: there is no certain 
rule to guide you : but when fishing slow water to cast across, let it sink, and draw it slowly round, but do not make circles on the water. But the general practice was to keep the fly on the top of the water.

The fisherman waded, but only sparingly. $\mathrm{He}$ did not possess the hardihood of Scrope, who tells you never to go into water deeper than the fifth button of your waistcoat, and even this is inadvisable for tender constitutions in frosty weather. He advises those who are delicate and wade in February when it freezes very hard, to pull down their stockings and examine their legs. Should they be black or even purple it might perhaps be as well to get on dry land, but if they are only rubicund you need not worry. The seventeenth century was not so stalwart. Wading, not deep, must have been practised in large rivers, for in Tweed or Eden or Wye you would not get many trout in low water unless you waded. But it is rarely mentioned at this time, nor can I recall any print that depicts it. Wading boots were not in general use till later, and wading trousers or stockings not till later still.

There were two schools of striking as there always are, according as the writer is talking of large fish or small. Large fish should not be struck before they turn, for small ones you cannot be too quick. The fish when hooked was played with the rod, as in the time of the Treatise, and if of any size was landed in a net, 
usually by an attendant. Landing nets are first mentioned by Dennys in 1613 , and were in general use in Walton's time. The triangular net now so common is first shewn in a French book, the Ruses Innocentes of Frère François Fortin, concerning whom I have already written in Chapter IV. Venables tells you that the screw handle of your landing net should be able to take a gaff as well as a net, and that you are to carry two other hooks to fit the same socket, one to cut weeds and the other to pull out snags.

Catches were big, but not excessively so: bigger perhaps than now, but certainly no bigger than in the nineteenth century. Cotton mentions thirty-five to forty trout as an exceptional take, and indeed this number from the Dove, where I suppose the average would not be much under a pound, is a good day. It seems to have been exceptional, for when his pupil catches six trout and three grayling, Cotton calls it a pretty good morning's work. Barker does not give the number of his mighty draught. Cotton, inventor of the clear water worm, says that if you will wade and fish the worm upstream you can catch as many fish as you like. Records are scarce; but altogether the impression left on the mind is not one of big bags. Walton and his pupil in the only day's fly fishing recorded caught no more than ten, and his brother Peter and Coridon five between them. Compare these with more 
modern records. Stewart considered that a good fisherman should average fifteen pounds a day and a first-class one twenty pounds all through the season. Twenty pounds means at least forty fish in the waters Stewart fished, and as everyone has many blank and bad days an average of that number means formidable baskets on the good ones. Stoddart says that a good rod could take from twelve to thirty dozen in a day and that a friend of his caught two hundred and eighty fish in six or seven hours. He adds that thirty pounds weight was a good day on Tweed and few anglers attained it. I can quite believe it. Henderson relates how three rods on Coquet at Easter killed five hundred and seventy-five trout in six days. Younger's grandfather was reputed to have killed thirty-six dozen in Kail water in one day with the worm, and a nephew of Younger's killed eighteen dozen in the same water with fly. To come to more recent times, Hamilton writing in 1884 says that he and another rod took with the fly in one July day before two o'clock in the Ramsbury water of the Kennet forty fish, none under one pound, some between two and three and three over three pounds. Within my own day one hundred fish have been taken with the dry fly on the Gade at Cassiobury. When I started fishing the Cumberland Eden thirty years ago, a stone weight, say forty fish, was a good day for a good rod, but not at all uncommon. The doings of the redoubtable 
Dickie Routledge had perhaps by that time acquired some of the glamour that belongs to the legendary, but he was reputed to have been able regularly to take one hundred trout on an average day, and I quite believe it. These records, as far as they go, show that bags were not exceptionally heavy in Cotton's time. Possibly poaching accounts for this : he makes bitter complaint of it.

Before the time of Stewart fly fishing was not much practised in summer or calm hot weather and in low clear water. Consequently in Cotton's day, either a cloudy day or a water clearing after rain was preferred at any time, and in clear water in summer either wind or cloud was essential. In the spring, on a rough day, fish the still deeps : in a calm or light breeze the fast streams. The artificial mayfly is little use except on a rough windy day. March, April, May and June are the chosen months, and of course July and August always have been notoriously bad for the sunk fly. The floating fly has changed all our weather lore, for it succeeds best on days when the sunk is hopeless and will kill in a wider range of weather than any other lure, natural or artificial. The directions as to weather and water in the seventeenth century are the same as in the nineteenth before Stewart wrote.

* (page 70) Sir David Prain, the distinguished Director of the Royal Botanic Gardens at Kew, has thrown himself wholeheartedly into the quest, in which all the resources of $\mathrm{Kew}$, helped by the India Office, have been engaged. But he cannot yet say with certainty what the substance was. 


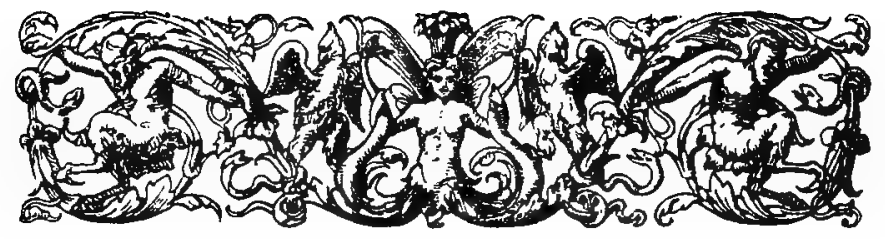

\section{CHAPTER VI.}

\section{FROM COTTON TO STEWART.}

The quiet pastime of their choice

On Beauly rocks, in Derwent glades, Still seems to move to Walton's voice,

Singing of dace and dairymaids :

His water meadows still are wet,

His brawling trout streams leap and glance, And on their sunlit ripples yet

The tlies of his disciples dance.

\section{Collected Verses.}

Alfred Cochrane. 1903.

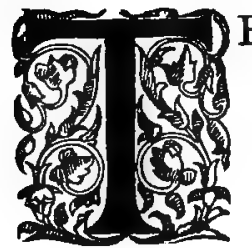

HE one hundred and eighty years which separate Stewart from Cotton are years of advance which, though great, proceeded by hardly perceptible stages. At the beginning men fished with no reel, twisted hair lines, long rods, and a single fly. At the end they used short rods, sometimes of split cane, reels, silk lines, and drawn gut, and, except those bold adventurers who used the dry fly or on very shy waters, two or three flies. These great changes were evolved so slowly that the period cannot be divided 
into epochs. Advance followed advance by measured and orderly procession; we are hardly aware that we are travelling, and it is only when we have reached the end and look back that we are conscious of the distance which we have covered.

But from another point of view the period shows a marked division. Up to the end of the eighteenth century it was one of technical rather than intellectual progress: a progress wrought by the tackle maker rather than by the writer or thinker. No great names stand out. There are neither great masters of the rod nor great masters of the pen. I know of only one eighteenth century prose writer, and he an unimportant one, included in the very catholic ambit of the Dictionary of National Biography, whilst in the seventeenth and nineteenth centuries there are many. Indeed I am not sure that the best writing is not to be found in poetry. Of Gay's Rural Sports, excellent though unequal, the most excellent are the passages describing fishing. He was clearly a good performer. A Barnstaple man, he had at his door an unrivalled territory, and it was probably there that he learnt his devotion to the fly.

Around the steel no tortured worm shall twine, No blood of living insect stain my line :

Let me, less cruel, cast the feathered hook, With pliant rod across the pebbled brook. 
The classical style is a bad medium for field sports: Gay's merit is that his love of the country and knowledge of its pursuits triumphs over the conventions of his age. At first sight it is not a little surprising that the eighteenth century, with its amazing literary and artistic fertility, produced no great angling prose writer. It cannot have been a matter of chance, for neither did it contain many great works on hunting; indeed, I can recall none, save that of the admirable Peter Beckford. On the other hand, the first half of the nineteenth century is wonderfully rich. Sir Humphry Davy and Fitzgibbon, Bainbridge and Ronalds, Pulman and Penn, Stoddart and Colquhoun were all fishing and writing: Christopher North was living as well as describing his Ambrosial Nights: whilst one greater than them all was content to subscribe himself as

\section{No Fisher}

But a well-wisher

To the game.

and to do so in the words of a seventeenth century writer. It is difficult to imagine Scott quoting an eighteenth century poet, even one so good as Gay, and it is impossible to imagine him quoting Pope, though he did write on fishing.

The patient fisher takes his silent stand

Intent, his angle trembling in his hand.

We have got a very long way indeed from the 
river, and the open sky, and the wind blowing over the reeds. The eighteenth century was barren of fishing writers: in the nineteenth they sprang into being on all sides. The classical school offered an unfruitful soil, and it was the romantic revival which brought them into lusty life. Scott was no fisher, yet but for him Stoddart and Colquhoun might not have written. Waverley influenced more than the novel and Marmion more than the epic.

In the eighteenth century, therefore, we have no great prose writers. We have manuals, some bad, some good, one at least excellent, and we have many rather unimaginative compilations. But more important than the writers is the advance in mechanical appliances.

The rod comes first. At the end of the period under review, Stewart considered a ten foot rod, if stiff, big enough for any water, and adds that he generally used one from eight to nine feet long. This is a big drop from Cotton's fifteen or eighteen footer. The drop occurred after the reel came into general use, which revolutionised rod making, for it enabled men to fish fine with a short rod, impossible before. Still, rods remained long for years after the reel appeared, and Stewart is somewhat exceptional. Indeed, Francis, writing ten years after Stewart, gives the lengths of four typical single-handed fly rods, and they vary from eleven feet seven inches to twelve feet eight inches. As late as 1886 Halford says that a 
strong man can use a twelve foot rod for dry fly fishing, though he changed his views in later years. I started by using a twelve foot split cane on the Test, Itchen and Kennet, and I do not think I broke oftener than I do now with a nine or ten footer. During the eighteenth century, after the reel, twelve to fourteen feet was not uncommon. The jointed rod is first mentioned by Lawson in 1620, but was not much used till the eighteenth century. Lawson's rod, and the eighteenth century rod, was spliced. He says : 'I use a rod of two parts to joyne in the middle when I come to the river, with two pins, and a little hempe waxed, thus the pins joyne it, the hempe fastens it firmly.' As late as Stewart's time many people, himself included, preferred spliced rods to ferruled. Indeed, spliced rods survived much later, and have by no means disappeared to-day. They disappeared in proportion as the workmanship of the ferrule improved. In the older rods it had many weaknesses : the joint either worked loose or jammed : the rod was amazingly apt to break either in the socket, or just below the joints, disasters impossible to repair : and the heavy metal work then necessary hindered the play. Modern rod-making, to which intense technical skill has been applied, gradually remedied all these defects; but it was not till the eighties that the balance swung definitely over to the ferrule. Wells'American Salmon Fisherman in 1886 and Halford's Dry-Fly 
Fishing in $\mathbf{1 8 8 9}$ gave the splice its quietus. The great evil of the splice (beyond its troublesomeness to adjust) is that nothing ever invented prevents it working slightly loose after a long period of fishing : nothing, that is, except the glueing together of the tapered ends, when the rod becomes one of a single piece.

All this is anticipating slightly. To go back to the time I am describing, the ferrules then used were of the simple kind, and to prevent them slipping round every well-made rod had a flat wire loop fixed immediately above and below each ferrule, under which a bit of string was easily run for two or three turns of a figure-of-eight after the rod was put up. This prevented the joint slipping round. The lockfast and suction joints now so common came later.

It is a curious fact that ferruled rods are actually older than spliced, for the rod described in the Treatise is a jointed rod in two pieces, ferruled with iron or tin: but the jointed rod did not long survive, and the rod in one piece was the usual thing in the sixteenth and early seventeenth centuries; next came the spliced rod and lastly the ferruled.

Silk lines are first mentioned in Nobbes' Compleat Troller 1682, and came gradually into use. But hair lines long survived, for I can recollect their still being used by the oldfashioned at the end of last century, and no doubt some could be found even now. The silk 
lines used were like those of my boyhood, light and thin, mighty difficult to cast compared to the heavy tapered article now in use.

Now as to reels. Here again the practice varied greatly. David Webster in his entertaining and practical book, The Angler and the Loop-Rod, was still using no reel as late as 1885 ; but he is a bit of an eccentric, in that as in other matters. He was a century behind his time, for reels for salmon fishing were in general use by the beginning of the eighteenth century, and for trout fishing during its last half. They were plain barrel winders of brass. The multiplying reel also appeared. The first mention $\mathrm{I}$ know is an advertisement of the tackle maker Onesimus Ustonson, which is at the end of my copy of Smith's True Art of Angling, 1770 edition. Best in his Concise Treatise 1787 recommends its use in fly fishing, and putting these two notices together, it must have been not uncommon at that time. Two, three, or four flies are recommended by Robert Howlett in the Anglers' Sure Guide 1706, and this number was common throughout the period; but in this matter also Webster was an eccentric, for he never used less than the terrific number of nine, though he allows the novice to begin with six. The single fly was by no means discarded ; many skilful fishers recommend it, and of course for the dry fly, just beginning to emerge, it was essential.

Modern fly dressing starts with Bowlker's 
Art of Angling 1747.* When he wrote he found most authors, overlooking the highly original work of Chetham, engaged in slavishly copying either the Treatise or Cotton. Bowlker gives a list of twenty-nine flies, all easily recognisable; and what is more important he definitely rejects 'many other Flyes taken Notice of in Treatises of Angling,' among them most of our old friends which date from Dame Juliana. And it was high time they went; for their original derivation had long been forgotten, their very names were corrupted and had become meaningless counters, unrelated to the natural insects from which they were copied. Bowlker pillories them by name, and from his time the Ruddy Fly, the Sandy Yellow Fly, the Moorish Fly and the Twine Fly disappear from fishing literature. Cotton, it is true, had preceded Bowlker in rejecting them, and so had Chetham; but Cotton did not renounce them by name, and indeed could not because of filial piety, for Walton had swallowed them whole. Besides, Cotton's list is too long and the attribution of his names to natural flies is often impossible; added to which the list of the Treatise was repeated by many writers long after Cotton. After Bowlker it disappears, and instead his list survives with little change till to-day.

* The first edition of Bowlker is undated, but Mr. Turrell in Ancient Angling Authors says that it is dated 1747 in the catalogue of the Bodleian Library. Bibliotheca Piscatorta gives 1758 , with a query. 
Perhaps this is the place to say something about Bowlker's Art of Angling. There were two Bowlkers, Richard and Charles, father and son, of Ludlow in Shropshire. The first edition in $\mathbf{1 7 4 7}$ is by Richard; but in the third edition of 1780 (the second edition of 1774 I have never seen) and all subsequent ones Charles Bowlker is given as author. He died in $\mathbf{1 7 7 9}$, and was accounted the best fly fisher of his day. After his death the book continued to be issued under his name till 1854, some sixteen editions or more, a record surpassed by no fishing book except the Treatise and the Compleat Angler. It is the best book by far of the period and an excellent manual. Its excellence lies in three features: the directions for fly fishing, including one of the early recommendations of upstream fishing, the directions for fly dressing, and the knowledge shewn of the life of the natural fly, which is much in advance of anything that had appeared before.

Woods used for rod making underwent a revolution; for, owing to the increasing facilities for importing the superior transatlantic products, native woods largely disappeared. No more is heard of hazel, the universal favourite of early fishers, and still less of eccentric materials such as crab tree, juniper, medlar, blackthorn and yew. Ash and deal alone survived, and they were only used for butts. Four imported materials took their place, hickory, lancewood, bamboo and green- 
heart. Hickory, an American wood, was extensively used for many purposes from the seventeenth century onwards, but it is not mentioned as a rod material till Snart's Practical Observations on Angling in the River Trent, published anonymously in 1801. It became the common material for trout rods. Lancewood, from the West Indies, began to be used during the period. Greenheart, a native of the West Indies and South America, but coming chiefly from British Guiana, now so universal and invaluable, was not used for rods until nearly the end of the period, though its fine qualities for other purposes, such as shipbuilding, were known long before. In 1841 occurs the first fishing mention I know of: Edward Chitty, who wrote the Fly-Fisher's Text Book under the pseudonym of Theophilus South, says that Liverpool rod makers use a wood imported from Essequibo River, British Guiana. This wood can be none other than greenheart, which comes from there. $\mathrm{He}$ considers it a good material, but too stiff for tops. A few years later Mr. George Kelson, as he tells us in his Salmon Fly, made with the help of a friend a greenheart trout rod, with which he could cover more water than with the hickory rods then in common use. In 1857 Stewart mentions greenheart, but only as material for tops, for which he rejects it as too brittle, and also because its weight strains the middle joints and makes the rod too pliant. 
Ten years later still Francis, though he refers to the noble qualities of greenheart for salmon rods and had his four salmon rods made almost entirely of it, yet had not a single joint of greenheart in the four single-handed trout rods he portrays: one was a hollow cane with an ash butt, two all of hickory, and one of triangular glued cane. He thought the Castle Connell salmon rod all of greenheart then coming into fashion so topheavy and small in the butt as to be entirely detestable.

Like most fishing inventions the split cane rod, composed of sections split lengthways and glued together, is far older than generally imagined. But here it is necessary to distinguish between the rod composed of two, three, or four sections, which is old, and the rod composed of six similar sections, which is more modern. The four-sectioned rod is first mentioned by Snart in 1801. Bamboo, briar, and elder were divided lengthways into four pieces, thick enough to form the joint. Bamboo was preferred for fine tops, but briar was cheaper and little inferior, and could be found plentifully in old hedges. It must be thoroughly seasoned before it is split, or the sections will warp in drying. Elder is rather brittle, and was never used when cane or briar could be procured. The split cane rod came steadily into fashion, and is mentioned by nearly all writers from 1840 onwards. Three London tackle makers, Aldred, Bernard and 
Farlow, exhibited rods of this description in the Royal Exhibition of 1851, and Little was at the same time making salmon rods whose middle and top joints were of three-sectioned bamboo. Stewart, also, mentions the two or three-sectioned trout rod, but rejects it as too expensive, though he likes a split cane top with a whole cane butt and middle joint. Francis had a triangular split cane rod made by Aldred, a beautiful piece of workmanship, but top heavy and tiring to the arm and lacking in free spring.

The three or four-section split cane was, unlike the six-section one, an English invention. I think its originator was almost certainly Higginbotham, who in the early nineteenth century carried on business at 91 Strand, London. Two pieces of evidence point in this direction and, though neither of them is conclusive, together they make a strong case. Snart, the first to mention split cane, particularly praises the workmanship of London rods, and, on the page before he mentions split cane, specially recommends Higginbotham. And Wright, author of Fishes and Fishing, published in 1858, gives a circumstantial account of getting Clark 'the unrivalled maker of glued-up cane fly-rods' to make him one in the year 1805. Clark was Higginbotham's successor at 91 Strand: and these two facts taken together afford fairly conclusive proof. At any rate I know of no earlier maker. Green- 
heart, when it came in, superseded the three or four-sectioned split cane, for it was much easier to work, cheaper, and for all practical purposes as good. Greenheart in turn was ousted by the six-sectioned split cane, which has now spread all over the world, and is used by everyone who can afford it. It was invented in America, but the actual inventor and exact date are still under dispute. The originator was probably Samuel Phillipe, a gunmaker, of Easton, Pennsylvania. He was experimenting with three and four-sectioned rods in the forties of last century, but failed to make a success of them, and invented the six-section rod. He taught the secret to Charles F. Murphy, who in the sixties was making them for Andrew Clerk and Company, of New York. Therefore probably Phillipe invented it in about the year 1850, and Murphy made it a commercial possibility in $\mathbf{1 8 6 0}$ or thereabouts.*

Silkworm gut is first mentioned by James Saunders in 1724 in the Compleat Fisherman. After saying that the Swiss and North Italians are the best trout fishers in the world, owing to the many fine streams they possess, he says that they make a fine and exceedingly strong line, drawn from the bowels of silk worms; like catgut from which viol strings are made, it is so strong that nothing of so small a size can

\footnotetext{
*I am indebted to Mr. R. L. Montagu, of Oroville. California, for much of this information about the history of split cane. He has made a study of the subject, and has been good enough to allow me to make use of his knowledge
} 
equal it. It is smaller than the single hair ordinarily used. $\mathrm{He}$ adds: 'I have seen an imitation of these Worm Gut Lines in England, and indifferent strong too, but not like that I have mentioned in Italy; yet these will hold a fish of good Size too, if she is not too violent, and does not nimbly harness herself among Weeds, and Roots of 'Trees.' Gut came into use only gradually; and was hardly known until the second half of the eighteenth century. In 1770 Onesimus Ustonson the tackle maker advertised 'a fresh Parcel of superfine Silk' Worm Gut, no better ever seen in England, as fine as Hair, and as strong as Six, the only thing for Trout Carp and Salmon,' and Bibliotheca Piscatoria quotes an advertisement of George Bowness of Bell Yard, another London tackle maker, where silk worm gut is advertised as a new article in $\mathbf{1 7 6 0 . ~ I t ~ i s ~}$ seldom mentioned in the eighteenth century; but it became universal soon after its close. Sir Humphry Davy mentions it in a passage headed May 1810, and Penn in his Maxims (1833), which is a description of the Houghton water on the Test, does not think it necessary even to allude to hair as an alternative.

Rings are first described by Howlett in $\mathbf{1 7 0 6 .}$ They were upright, those on the butt being loops of stiff iron wire driven into the rod, and for the top loops of brass were lashed on lengthways and then turned up at right angles so as to stand out. They are therefore more like the 
modern upright rings than are those which superseded them, which were rings so lashed on as to lie flat when the rod was not in use, a great convenience for packing, but not nearly so free running as the upright or snake rings which have taken their place.

These details are dull, I know, but it is necessary to understand them in order to appreciate the technical advance which fly fishing made during the eighteenth century. At its beginning, men fished much as they did in the fifteenth : at its close, everything that we have now was in use except the American split cane rod. Reels, lines, gut, flies, net, basket : all were there.

In the first half of the nineteenth century, fishing, which had fallen somewhat into literary eclipse, burst suddenly into light again. Famous men once more wrote about it, most of the world practised it, and those who did not read about it. This was due in great measure to the immense popularity of everything Scotch which the Waverley novels induced, and under this influence a band of writers arose who were read not only on their own merits, which in any case would have brought them to the fore, but also because they described a newly-discovered country. Stoddart and Colquhoun, Scrope and Professor John Wilson as well as lesser lights, were writing copiously, and their output shows that the world's power of absorbing fishing literature 
was enormous. At the same time in England Sir Humphry Davy, as a bye product during ill-health, gave the world a book whose merits are often disregarded, largely I believe because it is written in dialogue, a literary form which that great man was lamentably incompetent to handle. He wrote it, Scott reviewed it in the Edinburgh Review, and the world read it. Penn, too, wrote a good book, invaluable for its description of contemporary fishing on the Test; Charles Kingsley made fishing an element in muscular Christianity : while Pulman, withdrawn from view in the West Country and musing on problems of fishing where the clear Axe winds through level meadows, suddenly, and all unnoticed till long after, produced the theory and practice of the dry fly full grown from the brain of its parent. It was a great age, the union of fishing and letters, long divorced. Fishing was fashionable. The names of writers on the sport were household words; for who had not heard of Thomas Tod Stoddart, equally famous as fisherman, writer and poet? We are still living under the influence of those great anglers, and my own generation certainly was deeply moulded by them. I suppose that for those now starting to fish Halford and Lord Grey take their places, and they are worthy to fill them. But I for one would not exchange my privilege of having been brought up under an earlier age. Stewart was the first fishing book I owned; and 
Stoddart, Colquhoun and Scrope led me to that land of enchantment whose magic does not fade as I grow older. I have never fished the Tweed and do not know it, but I hardly feel I need to, so clearly is it pictured in their writings. They and their fellows threw a glamour round it, and made it to the fisherman what Leicestershire is to the fox-hunter or Hampshire to the dry fly man.

This age of literary achievement was barren of technical advance. It was as though progress proceeded by alternate paths. The eighteenth century saw the perfecting of implements: when this was done, the way was clear for the movement of the nineteenth, which was in the mind of man. When both had taken place, when mental and technical equipment were equal, then some great movement was sure to come. And come it did. During the period under review Stewart was fishing and thinking, and it was not long before he took the world into his confidence. 


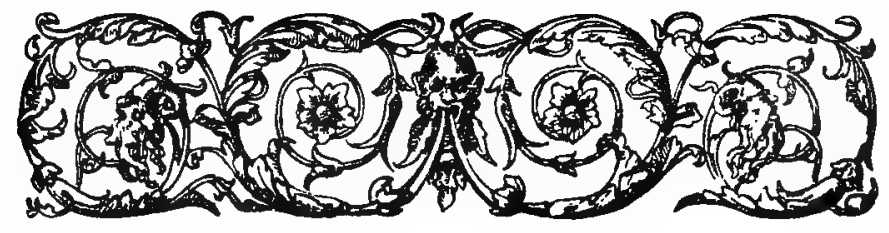

\section{CHAPTER VII.}

\section{STEWART AND THE UPSTREAM SCHOOL.}

Fish take all sorts of baits most eagerly and freely, and with the least suspicion or bogling, when you present the same unto them in such order and manner, as Nature affords them, or as themselves ordinarily gather them.

The Experienced Angler, Robert Venables. 1662.

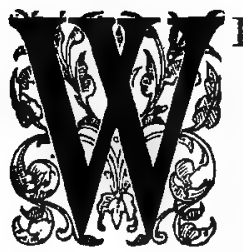

HEN the shape and colour of flies had been copied, men turned their minds to copying their movements and behaviour. This is the second of the four great landmarks of fly fishing. The fisherman is no longer content with imitating nature only in the construction of his fly, imitating her correctly, it may be, but then casting it on the water anyhow, trusting that its resemblance alone will suffice. No: he carries observation a step further, and he notices and copies the behaviour and action of natural insects as well as their shape and colour. This is a profound change, and opens 
a new field for observation and experiment.

Upstream fishing is much older than is generally imagined. It is first mentioned by Venables, in the Experienced Angler, published in 1662, a year after the third edition of the Compleat Angler. The quality of the book is proved by the fact that it ran rapidly through five editions, and that Walton, who wrote a preface, thought it worthy of forming the third part of the Universal Angler, published in 1676, of which the first and second parts were his and Cotton's books. Venables is so important that he must be quoted :

'And here I meet with two different opinions and practices, some always cast their flie and bait up the water, and so they say nothing occurreth to the Fishes sight but the Line: others fish down the River, and so suppose (the Rod and Line being long) the quantity of water takes away, or at least lesseneth the Fishes sight; but the others affirm, that Rod and Line, and perhaps your self, are seen also. In this difference of opinions I shall only say, in small Brooks you may angle upwards, or else in great Rivers you must wade, as I have known some, who thereby got Sciatica, and I would not wish you to purchase pleasure at so dear a rate; besides casting up the River you cannot keep your Line out of the water, which we noted for a fault before; and they that use this way confess that if in casting your flie, the line fall into the water before it, the flie were better 
uncast, because it frights the fish; then certainly it must do it this way, whether the flie fall first or not, the line must first come to the fish or fall on him which undoubtedly will fright him : Therefore my opinion is, that you angle down the River, for the other way you traverse twice so much, and beat not so much ground as downwards.'

Several points call for particular notice. First of all Venables meets with two different opinions and practices, and therefore even in the seventeenth century the two systems existed side by side. Then he gives the argument. The upstream man claims to keep out of sight. But the downstream fisher effects the same object by throwing a long line. That he must throw a long line is true then and always. There are still, and always have been, two schools, those who use a long line down stream and those who use a shorter line up. And Venables also is emphatic on the danger of lining your fish, a point often overlooked, but one of great importance. It is instructive, by the way, to see that it was as fatal to line a fish two hundred and fifty years ago as it is to-day. And he says, which is also true and said for the first time, that in fishing straight up his hair and our gut must go over the fish. He also makes the point so often made since, that upstream fishing means laborious wading and covers less water than downstream. It is interesting to find the argument put so com- 
pletely at this early stage : it shows surely that the question was no new one : it must have been discussed by anglers and argued long and often at the waterside when fish were not rising. Venables sums up in favour of downstream fishing, except in small brooks, but the point to notice is not the actual decision he comes to but the evidence he affords that upstream fishing was understood and practised.

So profound is the influence of upstream fishing that it is worth while spending time in tracing its continuous history from Venables who starts it in 1662 to Stewart's Practical Angler in 1857, after which it was never seriously questioned. This is all the more necessary, as its history has been misunderstood, for the ordinary fisherman if asked who started upstream fishing would probably answer Stewart, whereas as a matter of fact it was both developed and described two centuries earlier. In order to trace its course I propose to select eighteen of the best writers on fly fishing between 1662 and 1857 and to see what they said, choosing six who wrote in the seventeenth century, six in the eighteenth, and six during the first half of the nineteenth, or rather before 1857, when Stewart wrote. They are chosen impartially, as the best authorities, not because they favour one school or the other.

Who shall be chosen? For the seventeenth century the choice is not difficult. Franck, 
Barker, Venables and Cotton should all be included : not Walton, who was not really a fly fisher. Next certainly should come Chetham, who wrote a good manual, though largely pirated, and for the last place either Smith, author of the True Art of Angling, a book which went through twelve editions and was a standard work for three quarters of a century, or Cox's Gentleman's Recreation, a summary of the current practice of the time. Possibly the True Art is the best, for Cox is really not much more than a copyist. The eighteenth century is more difficult, for though there are many books there are few good ones. The most famous was that of the two Bowlkers, father and son, whose Art of Angling, published inconspicuously in 1747, ${ }^{*}$ was republished every few years for over a century. The next in merit is probably Best. For the other four we will take Howlett, Brookes, Shirley and Scotcher. In the first half of the nineteenth century there are many names to choose from and famous ones too. Sir Humphry Davy, Stoddart, Colquhoun, Fitzgibbon, Pulman, Penn, Younger, Bainbridge, Jackson, Theakston and Ronalds; what a list of mighty hunters. Choice is difficult. Stoddart and Ronalds cannot be left out, nor Fitzgibbon either. Then Penn should come, for he is representative, recording as he does the practice of the Houghton Club on the Test, and for the last two we will take * See note on page 89 as to the date of Bowlker. 
Sir Humphry Davy, and possibly Younger.

So much for the names: now to collect the votes. Franck tells you to start at the head of the stream, at least I think he means that, though Franck never talks plain English. But he shall be counted downstream. Barker is the same. Venables, as has been seen, is neutral, inclining to down. What of Cotton? He is generally classed as a downstream man, and certainly his phrase 'fine and far off' seems to put him in that category. This, however, is not the whole truth. He tells his pupil to have the wind always at his back, and to fish up or down the river as the wind serves. He therefore fished not downstream, but down wind, and indeed he could do little else, using as he did a whippy single-handed rod fifteen to eighteen feet long. But he knew the advantage of fishing still water upstream. Thus on the second day of the Dialogue, when 'the wind curles the water and blows the right way' Cotton sets his pupil to 'angle up the still deep,' and therefore chooses a day of upstream wind in which to fish still water. And let it be noted that Cotton is the inventor of upstream worm fishing. Cotton is therefore not the downstream man he is generally supposed to be, and he also must be classed as neutral. Chetham (1681) is on the whole a downstream man, for both he and also the True Art of Angling (1696) tell you to fish upstream in clear water with the natural fly, 
but downstream in a thick water or with the artificial. Therefore the verdict is four in favour of downstream, Franck, Barker, Chetham and Smith; and two, Cotton and Venables neutral, inclining rather to down than to up, but showing that an upstream school existed.

In the eighteenth century Bowlker (1747) says that "when you see a Fish rise at the natural Fly, the best way is to throw a Yard above him, rather than directly over his Head, and let your Fly move gently towards him, by. which means you will show it to him more naturally.' Wise and admirable man! It is not clear whether he means you to fish up, or across, or across and up : but the point to bear in mind is that you are to cast above and let the fly float down, and he belongs to the upstream school. Best, in the Art of Angling (1787) is not clear, but he is probably a downstream fisher. Howlett's Angler's Sure Guide (1706) and Brookes' Art of Angling (1740) both recommend downstream. Shirley in the Angler's Museum (1784) copies Bowlker, and is therefore upstream. Scotcher, in his quite excellent manual (I wish it were not so scarce) the FlyFisher's Legacy (about 1800), bids you sometimes to throw up a stream and sometimes down, as you can best be hidden, treating concealment as the more important factor. Therefore the verdict is three, Best, Howlett and Brookes in favour of downstream; one, 
Scotcher, neutral, and two, Bowlker, most famous of all, whose sales probably exceeded the rest put together, and Shirley who copied him, in favour of up.

Coming to the nineteenth century, Sir Humphry Davy* put his mayfly a foot above a rising four pounder, and advises the novice to throw half a yard above another monster. This also might be either up or across, but we can reckon Sir Humphry an upstream man. Penn, whose amusing Maxims (1833) are taken from the Common Place Book of the Houghton Fishing Club, tells you that you will rise more fish by fishing down but hook more by fishing up, and that you will not disturb unfished water by killing them. Stoddart apparently began angling life by fishing down, but tells you not to lead your hooks [draw your flies], a necessary feature in downstream fishing, and as he is one of the first writers to mention the dry fly he must have fished up, though he does not say so. Ronalds in that glorious book the Flyfisher's Entomology (1836) advises throwing across and down. Younger (1840), one of the best fishermen that ever lived, tells you to throw aslant upwards or straight across rather than downwards, and to allow the fly to float down the current of its own accord. One writer, by the way, Blakey, quite a competent authority, in his Hints on Angling (1846) inveighs against

\footnotetext{
"Salmonia was published in 1828 , but the chapter in question is headed 'May 1810.'
} 
the many crotchety and fanciful rules laid down by angling writers. Of these the most preposterous is that of upstream fishing. It is almost impossible for a trout to seize a fly in this position, and if he does you can neither hook nor hold him. Fitzgibbon who wrote his Handbook of Angling in 1847 under the pseudonym Ephemera tells you to use both methods, but to fish upstream first. Therefore four, Davy, Penn, Younger and Fitzgibbon are upstream, and two, Stoddart and Ronalds, not counting Blakey, are downstream. The whole result of an enquiry over two and a half centuries shows a numerical majority for fishing downstream, but also a steady increase in the upstream witnesses: none in the first period, two in the second and four in the third, when the balance swings finally over to upstream before Stewart appears on the scene. Also the habit of fishing upstream began earlier and was more generally used than is commonly supposed, and it is unlikely that there was any period from Walton's time to now when it was not practised. I believe, though it cannot be proved, that it depended on locality, and that Scotland and the south of England fished down, the north of England up.

Stewart sets out to prove that fly fishermen can get almost if not quite as good sport in clear water as in coloured, if only they will consent to fish upstream. Ninety-nine out of a hundred, he says, fish down, and most books 
recommend it. The advantages of upstream fishing are that you are unseen by the trout, whom you approach from behind : you are more likely to hook your fish, for when you strike you pull the hook into him instead of out of his mouth : you do not spoil unfished water in playing a heavy fish : and you imitate the motion of the natural insect. With these advantages you can kill trout in the lowest and clearest water. His case is not difficult to prove, but he does it clearly and finally. He was not the discoverer of upstream fishing any more than Darwin was the discoverer of natural selection: but he was the first for nearly two hundred years to take the trouble to make the case and the first of any age to do it completely. He probably exaggerates the novelty of his creed, for it is difficult to believe that in 1857 only one in a hundred fished up, and the statement that most books recommended downstream is only true numerically, if at all, for as has been shewn the best books did not. Still all credit be given to Stewart, for he converted the world as Darwin did. His case was so convincing that no one has felt bold enough to dispute it. One or two tried to cross swords with him, as Cholmondeley Pennell did, but he found few to follow him, and speaking generally from Stewart's time to now the argument has been all one way and the written word has been unanimous in favour of upstream. Why the practice of mankind does not universally follow so obvious a theory and 
why many fishermen, who want to catch fish and are not fools, continue to fish down, is worth understanding. It is not for want of being preached at.

All logic favours upstream fishing, at least in clear water, and nothing else is worth talking about. There are not two sides to the argument. And the immense majority of fishing books say the same. But a history of fly fishing would not be complete if it left the matter there. Future students, reading the printed word, would imagine that from Stewart to now everyone fished upstream except some obscure individuals fishing untried waters. But that is historically untrue. Good fishermen, on the shyest of waters, fish downstream and kill fish. Their practice differs from theory, as it often does. Downstream fishing, here and now, in this twentieth century, is better for certain persons and certain occasions. You avoid many difficulties. Wading is easier, and casting less incessant. Your line is always taut and you are more likely to hook your fish. Also, as it is always taut you know where your fly is and know where to look for rises. This is a great difficulty of upstream fishing, especially in quick or broken water. You lose touch with your flies, as Lord Grey says; a rise comes, you see it too late and miss the fish. Or else you see nothing and do not even know a fish has risen. It is a far greater difficulty than the inexperienced imagine: the power of knowing when a 
fish has risen is the hall mark of proficiency. Many never attain it: and I fancy none do unless they are bred to it. And nothing is so fatal to its acquisition as a training on a chalk stream. If you have not got it, you must replace it at any price, and fishing downstream is not too high a price to pay.

Watch a good man at work and you will see what I mean. Let us suppose that it is a day in the first half of April. It has been a dry March and the river, a large one, is low and stainlessly clear. The trout are in the fast streams, but not in the thin water: they will not be there for a fortnight yet. Finally let us imagine that it is 11 o'clock in the morning: that the March Brown is on but not up; that the sky is blue with fleecy clouds and the wind light, and that you and I are seated on the bank watching a famous fisherman fishing up a famous river.

Though not a fish breaks the water, he at once begins catching trout. He moves quickly. He seems to fish with no regularity : a cast here straight up, then no more for several yards, though the stream looks to you just the same : then three or four casts across, slightly up : and then one right across, allowed to come round below him. So he goes on and soon wades out at the head of the stream; you have counted up and he has caught eight. Now, ask him how he managed to know that a fish had risen when nothing broke the water. Can he tell you? 
Very likely not. So minute and various are the indications, that it is often hard for him to say why he struck. Very seldom did he see any sign on the surface. Sometimes a movement under water made a slight, hardly visible boil: Or he may have seen a flash as the fish turned at the fly, or a dim shadow, scarce perceptible in the ripple. Or the line may have stopped for a fraction of a second, or behaved in some peculiar way. Our fisherman, wading out at the head of the stream, could not tell you if you asked why he struck in each case. All he could say was that he knew that a fish had risen.

All this is difficult, and if you cannot attain the art, fish downstream. It is also hard work, and if I feel tired and lazy I fish downstream. It also demands great concentration, which $I$ for one cannot give unless trout are rising freely. So if they are not, fish downstream until they start again.

Now, all this is a concession to fallible human nature. It does not affect the superiority of upstream. But there are occasions when, even in clear low water, downstream beats upstream on its merits.

It has been pointed out, I think by Lord Grey, that when you are fishing up a stream you will not uncommonly come across fish who, lying in midstream and apparently rising well, refuse your fly when cast over them from below and yet take it when cast from above, when it is swinging round and across the current. It 
happens frequently in north country streams and $I$ have known it occur on the Kennet, when fishing a sunk fly. In a long day's fishing you may get several such, and these are fish that you cannot catch fishing upstream. And there is no doubt too that occasionally you can get big fish in the clearest and shyest streams by fishing downştream with a long line. Sometimes too when the fish are sunning themselves in a sharp run you can kill fish by working downstream where you will not get a rise fishing up. In fast glides too, where the water runs at a great pace with a surface like glass, you often do better by fishing straight across or across and down than by fishing up. What the reason is I do not know. Again, in a stream which, shallow on one side, deepens and steadies towards the other, until close to the deeper bank there is slack water or an eddy, you will find, if you are fishing from the deep side, that it pays to cast across and let your flies swing round into the eddy. On these occasions, and others, you do best by fishing downstream.

The truth is that a sunk fly is often taken, not for a fly that has hatched out, but for a nymph or even for a shrimp or other aquatic animal, and as these swim vigorously a fly that moves against the stream imitates them correctly. We do not know always why trout take our fly, when they condescend to do so; in fact there is a good deal still to be learnt. All I can do is to suggest, as I have tried to do, 
certain occasions when the fly fished downstream pays best, without attempting to give the reason.

This is really a digression, undertaken in the interest of historical truth. Upstream fishing is firmly enthroned and will not be unseated. But the downstream method is used to-day to a much greater extent than books or newspaper articles might lead you to suppose. The wheel has turned, and whereas in the two centuries before Stewart men fished upstream but did not talk about it, so they practise a similar reticence to-day about downstream fishing. 


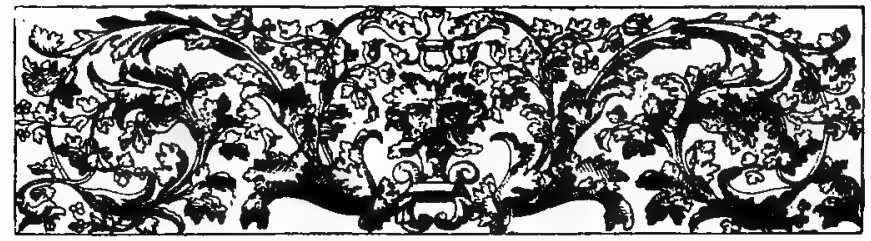

\section{CHAPTER VIII.}

THE DRY FLY.

And lightly on the dimpling eddy fling The hypocritic fly's unruffled wing.

The Anglers: Eight Dialogues in Verse.

Thomas Scott. 1758.

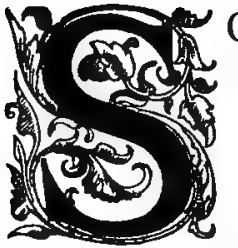

OMEWHERE during the first half of the nineteenth century, in the fulness of time, heralded by many precursors who just failed to reach completeness, the dry fly was first cast upon the waters. It forms the last and most notable of the four landmarks in the history of fishing, for without it the other three, imitation of the natural insect, upstream fishing and fishing for individual fish are imperfect and incomplete. What is the dry fly and what is the secret of its hold over the imagination? The explanation of what it is presents no difficulty, but its imaginative appeal is a different matter. Certain flies, such as mayflies, duns, alders, sedges, stoneflies and smuts at certain periods of their lives sit on the surface and are carried 
down by the stream. In this position they are taken by fish, and in this position the fisherman imitates them. For success he depends, apart from general fishing skill, on two things. His fly must imitate accurately a living insect. This alone does not distingush him from the wet fly man, for with the wet fly accuracy of representation is even more necessary. But besides imitating the appearance, he must also copy the behaviour, of the natural fly. Herein lies the difference : his fly must act as well as look like the real article. To effect this he must construct it so that it looks like a fly with wings unwetted and then cast it so that it floats over the fish with the current as the natural fly does.

Why is the dry fly used and who discovered it?

The reason of its use is easy to tell; it was the increased shyness of the fish. The actual inventor, unfortunately, is not known, that first explorer into a new world. But there is little doubt as to the process and method of his discovery. Stoddart says that every fisherman must have met with cases where the first cast of the day proved successful, because a dry fly is more likely than a soaked one to attract a crafty trout. A recent writer* quotes an old Wykehamist whose memory went back to 1844 when the systematic use of the dry fly was unknown on the Itchen. The boys used to look for a rise and made a point of putting their fly while still

"Chalkstream and Moorland, by Harold Russell (1911). 
dry over the trout. On changing flies they gave the new fly a similar chance, and occasionally would change flies merely to get a dry one. That is plain. They discovered that a dry fly is more attractive than a wet one : but what is the dry fly and what are we to call its invention? The test I suggest is the intentional drying of the fly, for until that is done invention is not complete. Using that test, the first mention of the superiority of a fly that floats over one that sinks occurs in the year 1800 , and the first mention of drying the fly in 1851. From this latter date the dry fly has a continuous history, but its use did not become common till 1860, nor was it till after the publication of Halford's books in the eighties that it spread to more than a few rivers. There are, however, passages in writers much earlier than 1800 which at first sight seem to hint at it, though I think it can be shewn that they refer to something quite different. These must be cleared out of the way before dealing with the dry fly proper.

Old writers, and new ones too for that matter, often discuss whether your fly should sink deep or swim near the surface. You are told that on occasions you will get better sport by sinking your fly, as for instance in still pools, in lakes on a calm hot day, or generally in cold weather. On other occasions your fly should be at or near the top. Early writers especially, fishing downstream with long rod and thick line, liked to keep their flies on the top of the 
water and liked flies which kept there and did not sink. And they advise you what materials: you should use for flies, and how you should. cast if you wish to fish near the surface. Now, in giving this advice they use words which in. the light of our after knowledge make them appear to describe the dry fly. They are really doing nothing of the kind. They are contrasting. not a floating with a wet. fly, but one which. swims at or near the surface with one which. sinks deep below it. Still less are they advocating what is the essence of the dry fly, that. it should float over the fish like the natural insect. Still perhaps the passages are interesting enough to be worth quoting.

The first goes right back to the beginning of things. Leonard Mascall in $\mathbf{1 5 9 0}$ gives a list of twelve trout flies. They are taken from the Treatise, without acknowledgment it is needless. to say. But there are two important additions. In describing the Ruddy Fly, which is clearly our Red Spinner, he says, what the Treatise' does not, that it is 'a good Fly to angle with aloft on the water.' And Izaak Walton follows: Mascall. And Mascall again at the end of the list adds something not in the Treatise, for he says, speaking of all the flies that he has described, 'thus are they made upon the hooke, lapt about with corke, like each fly afore mentioned.' Apparently, therefore, he intended each fly's body to have a cork foundation, which would tend to make it float, and one fly 
in particular is to be used aloft on the water. The passage looks uncommonly like prevision of the dry fly. Still I do not think this is the right interpretation. Mascall wanted a fly that floated aloft. Success in fishing in these early days of thick lines depended largely on keeping your line off the water and out of the trout's sight. You wanted therefore a fly that kept on the top, or near it. But this is not the dry fly. Barker's Delight (1657) has a not dissimilar passage. He says that hog's wool, red heifer's wool and various furs make good bodies: 'and now I work much of hog's wooll, for I finde it floateth best and procureth the best sport.' In this case it is certain that a floating fly is not intended, for he tells you to fish downstream and to let your fly fall on the water before the line, which are clearly directions which apply only to the sunk fly. Barker, in talking of a fly that floats well, means as Mascall means one that keeps on the top. It would be straining language to read anything else into the passages from Mascall and Barker. But they are of great importance in enabling us to understand their method.

The next reference, only a few years later, is much the same, and the only excuse for quoting it is the remarkable character of the author, Robert Boyle. Natural philosopher, chemist and theologian, a Founder of the Royal Society, the correspondent of Newton, Locke and Evelyn, he was not only one of the best 
known men of his time, but his services to science were great and lasting, not so much for what he did, which of course has been superseded, but because he practised and taught the experimental method, as opposed to the dogmatism which held the field in his day. He wrote on a wide range of subjects : on the air pump, which he perfected; on the elasticity of gases, on which 'Boyle's Law' is still recognised, on the temperature of the blood, on the properties of hydrogen and of white phosphorus, on seraphic love, on the iridescence of soap bubbles, on the weight of light, and among others, on fishing. Occasional Reflections Upon Several Subjects appeared in $\mathbf{1 6 6 5 .}$ It is a book of moral disquisitions and allegorical analogies, displaying perhaps a wide knowledge and some observation, but chiefly remarkable for its amazing lack of humour. No circumstance is too trivial to point the weightiest moral, or too ridiculous to be dragged into the loftiest metaphor. It afforded too easy a mark to escape satire in an age of satire, and it was parodied not only by the author of Hudibras in Occasional Reflections on Dr. Charlton's feeling a Dog's Pulse at Gresham College, but also by Swift in Meditations on a Broom Stick : a parody which, written to relieve the intolerable boredom of having to read the book daily to Lady Berkeley, he gravely palmed off on his patroness as an original. But perhaps its chief distinc- 
tion is that the Reflection entitled Upon the Eating of Oysters is said to have suggested to Swift the first idea of Gulliver's Travels.

The Discourses on fishing are similar to the rest. In Discourse IV. Eugenius went fishing. As he found the fish inclined to bite, he discarded his natural flies, and put on one of those counterfeit flies, 'which being made of the Feathers of Wild-fowl, are not subject to be drench'd by the water, whereon those Birds are wont to swim.' He has such good sport that his companion, after the inevitable moralising, starts fishing too. 'A large Fish, espying the Fly that kept my Hook swimming, rose swiftly at it,' whereupon the angler, strikes and hooks him, only to be broken ignominiously. It has been suggested that these passages refer to a floating fly, and the allusion to a fly 'which kept my Hook swimming' and was 'not subject to be drench'd by the water' is relied on in support. This seems plausible at first sight; but such a construction would be reading into the words more than they mean. As in the passages quoted from Mascall and Barker, I have no doubt that Boyle is describing a man fishing downstream, keeping his line off the water and his fly on the top. But perhaps he does go a step beyond Barker, for his fly is not drenched and therefore was actually dry. It is nearer, but the complete attainment was not to come for a century and three quarters.

It should, however, be said that Robert 
Boyle, though not a dry fly man, was a good fisherman. He describes himself as a great lover of angling, and says that his discourses are based on actual experience. It is to be regretted that so learned and so observant a man did not write on fishing for its own sake.

The desirability of keeping your fly on the top runs through angling history. As late as 1847, when the dry fly was appearing, Wallwork in the Modern Angler, an interesting and scarce book, says that in running water your fly must always swim on the top, under the continual inspection of your eye. But this also is not the floating fly.

The fly that floats, and kills fish because it floats, is first mentioned in a little book, Scotcher's Fly-Fisher's Legacy, published locally at Chepstow in 1800, and now excessively rare. It is known chiefly as the first to give coloured pictures of natural flies. Scotcher says that when trout are rising at black gnats in still water on hot evenings, you can catch them if you have a long rod, light line, fine point, small hook and neat fly, and keep off the water and throw with nicety into the ripple caused by the fish's rising, placing your fly in the direction in which he is swimming. He tied his fly, he says, on fine round glass-coloured hair, and used a casting line of single hair, which falls lightly and lies on the water, and the fly is frequently so taken. Unless you are careful, however, you will snap your fly off in 
casting. There is no doubt about that, for it is the taking of fish with a fly that floats, which takes them because it floats. But it still lacks the drying of the fly.

The next passages must be quoted at length. They are from Pulman's Vade Mecum of Fly Fishing for Trout. There are three editions of it, 1841, 1846 and 1851. This is what he wrote in 1841. He notices that the ephemeridæ sit upon the water, and that the trout station themselves just below the surface, and gently lift their noses as the flies sail over. Now a soaked artificial fly sinks, and thus escapes the notice of the fish who are looking upwards; but 'if the wet and heavy fly be exchanged for a dry and light one, and passed in artist-like style over the feeding fish, it will, partly from the simple circumstance of its buoyancy, be taken, in nine cases out of ten, as greedily as the living insect itself.' To insure this, however, it must be a good imitation both as to colour and size, for otherwise it will startle rather than attract.

The whole passage is an admirable piece of original observation. But it still lacks the finishing touch, which was not supplied until the appearance of the third edition in 1851 . The edition of 1846 only copies that of 1841 . That of 1851 takes the matter much further. It is not enough to have a good imitation. The fisherman must learn that something more than a good copy of the fly is necessary and that under certain circumstances not the form only 
but the action also of the natural fly must be imitated. 'Let a $d r y$ fly be substituted for the wet one, the line switched a few times through the air to throw off its superabundant moisture, a judicious cast made just above the rising fish, and the fly allowed to float towards and over them, and the chances are ten to one that it will be seized as readily as the living insect.' This is the earliest mention I know of the intentional drying of the fly.

The remarkable thing about this description is its completeness. The dry fly springs to view full grown : there are no tentative fumblings : we are given a full and reasoned argument, as good now as when it was written seventy years ago. All the attributes of the dry fly are present : a fish must be found taking natural flies; and the artificial must be a good imitation in colour and size : it must float on the surface; it must be cast lightly and float naturally. The fisherman must, says, Pulman, imitate action. Pulman was a well-known tackle maker at Axminster. He fished much on the Axe, on the eastern side of Devonshire. He wrote several good fishing books. The fact that he is the first to describe the floating fly is puzzling, for this reason. It was practised on the Itchen, probably in the forties, certainly in the fifties of last century. It has a continuous history on that river. On the other hand, I know no other reference to it on the Axe. Nor can I find any mention in Pulman's books of fishing on the 
Itchen. And yet Pulman must either have introduced it from the Itchen, or have discovered, or invented, it on the Axe. The last contingency is possible, but unlikely, for it would mean its invention at approximately the same time on two rivers widely separated in distance and character. And it is also unlikely for the reason that it does not appear to have survived on the Axe, where, however, it has been reintroduced. On the whole, while admitting that it is guess work, I incline to think it more probable that his knowledge came from Hampshire, directly or indirectly. $\mathrm{He}$ does not claim to be the inventor, nor does he write as such.

There appeared in 1879 a book entitled Ogden on Fly Tying. It attracted less notice than it deserved and is now somewhat hard to get. Its author, James Ogden, was a member of the famous house of fly dressers at Cheltenham, whose flies are as admirable now as ever. He says that his book is the result of seventy years' experience, and that he introduced floating flies some forty years previously, which brings us to 1839, or about the date of Pulman's first edition. He claims to be their originator. He gives a clear account of the first use of floating mayflies on the Derbyshire Wye at Bakewell on 5 June, 1865, where mayfly fishing was then done entirely with the live fly. Ogden's success caused the owner of the water to forbid the use of the natural, whereupon the 
other fishermen were so angry that he was mobbed and had to leave.

The book bears every mark of truth and accuracy. The account of floating mayflies on the Wye can be accepted confidently, for by 1865 the dry fly was in full swing on south country streams. But the case is not so strong with regard to the statement which he makes more than once, that he introduced floating flies forty years previously. Not that there is any improbability in it, but because of the general principle that statements in round numbers made long after the event should be accepted with caution. Still I believe it to be substantially true. I believe him to have been one of the first dealers to put floating flies on the market, his patterns are frequently mentioned by contemporary writers, and he is the first writer to give definite directions for dressing floating duns. If the reader wishes to see what - Ogden's Mayflies were like he can, if he is so lucky as to own that book which the hackneyed word 'unique' alone describes, Aldam's Quaint Treatise On Flies and Flymaking, find at the end of it two original Mayflies, tied by him. These I believe to be the oldest representations of floating flies now extant, and lovely flies they are.

In the Field for 17 December, 1853, an article signed The Hampshire Fly Fisher says that fishing upstream is very awkward 'unless you are trying the Carshalton dodge and fishing with a 
dry fly." Carshalton is on the Wandle, where the floating fly was practised early.

Mr. W. H. Foster of Ashbourne tells me that his firm made duns for dry fly fishing with upright split wings in $\mathbf{1 8 5 4}$.

Hitherto all information has come from the South, but for the next mention of the dry fly we must go to one of the most famous of Scots fishermen. Thomas Tod Stoddart wrote a book called The Angler's Companion to the Rivers and Lochs of Scotland, of which the second edition appeared in 1853. After saying that fishermen often find the first cast the most successful, because the fly is dry, he says that where the fisher has to deal with subtle trout in clear streams, it is not an unusual practice to describe a figure of eight twice or thrice in the air before casting, in order to dry your flies. This practice, or dodge, is much used by the fishers of clear, glassy streams both in England and Wales. Who would have expected to find an account of the dry fly in a writer so typical of Scotland? Yet he is one of the first to describe it. Whether he himself ever used the dry fly I do not know. One would like to think he did. I can find no reference to it in his other books; but the really interesting thing is that as early as 1853 the knowledge of it should have travelled north of the Tweed. And there is another point worth noticing : the first edition of the Angler's Companion came out in 1847,

*See the Fishing Gazette, $1 \mathrm{March}, 1919$. 
and in that the passage quoted above does not appear, while it does appear in the second edition in 1853. Therefore it is possible to fix with some accuracy the date when Stoddart first knew of the dry fly. This induces the suggestion that Stoddart, well read in angling literature, had got it from Pulman published in 1851 .

Francis, a celebrated writer, published an article on 12 December, 1857, in the Field, of which he had just become angling editor, on the Hampshire streams. Describing the Itchen, he says that however fine you fish, the motion of your line will at times startle the trout. 'Accordingly I recommend the angler frequently to try a dry fly-e.g. suppose the angler sees a rising fish, let him allow his casting-line and fly to dry for a minute previous to making a cast,' and then throw over the fish and let it float down without motion. This is a killing plan when fishing with duns. On rough windy days they get drowned, and trout will take a wet fly as well as a dry one, or perhaps better, but on a fine day they sit on the water with wings upright, and then scarcely a fish will refuse a fly that floats, if its belly, legs and whisks be of the same colour as the natural and the wings not too heavy. Francis says that he had long had these thoughts in his mind, and had had abundant opportunities of proving the advantages of the dry fly, which shows that he knew and used it long before 1857. You must throw your fly like 'thistle-down; do not let it 
dwell on the water too long, for many a fish will take it the second time, if you do not give him too long to look at it the first time.' And you must float it right over his head.

During the fifties, therefore, the dry fly slowly won its way: but by 1860 it had extended its range only over a limited area. Throughout the voluminous letters and writings of Charles Kingsley, who fished the Test and other chalk streams, it is not so much as mentioned. When he wrote Chalk Stream Studies in 1858 he clearly had never heard of it, for he insists not only on two flies, but on sunk flies too. He tells his pupil that a trout is more likely to take under water than on the top. His eager and enquiring mind was interested in the deeper problems of fishing: his letters are full of references: he fished until near his death in 1875 , and knew the south country rivers well; his knowledge of natural insects was far in advance of his time, and he is the first fisherman to mention the work of the famous Swiss entomologist Pictet. Yet, though of all men he would appear to be the one most open to the new idea, he never mentions the dry fly. It is difficult to avoid the conclusion that he never saw it. Nor is this intrinsically unlikely. Froude writing as late as 1879 evidently knew little of it, and what is even more odd, Sir Herbert Maxwell states that the Chronicles of the Houghton Fishing Club on the Test from 1822 to 1908 make no mention of it. Which is 
really amazing. True, it appears to have reached the Test some time after the Itchen, but of course it was the only method from the eighties onwards. When I first fished it in 1890 no one dreamed of using anything else, except on still water in a wind.

In spite of these isolated exceptions, by the middle of the sixties the dry fly had established its long reign on south country streams. Halford found it in full swing on the Wandle in 1868. Francis writing in 1867 ( $A$ Book of Angling) ten years after the article in The Field is able to say that by then it had become a systematic art, and was greatly used on southern streams. You should dry your fly with two or three false casts. In calm, bright and still weather, when a wet fly was useless, the dry fly was taken most confidingly. In rough windy weather, however, the wet fiy was preferable. He never contemplated using only the dry fly, even on the Test or Itchen, and he writes a sentence which, often as it has been quoted, shall be quoted again, 'the judicious and perfect application of dry, wet and mid water fly fishing stamps the finished fly fisher with the hall mark of efficiency.' But already there were those who thought otherwise, for anglers pinned their faith to the entire practice of either the one or the other plan, and argued dry versus wet. The battle had already begun.

Halford is the historian of the dry fly. $\mathrm{He}$ did for it what Stewart did for upstream fish- 
ing. Neither were pioneers, for both described what they did not invent; but both, by practice and writing, made an unanswerable case for the system they advocated. With Halford was associated a band of enthusiasts who devoted themselves to perfecting the art and spreading the creed. Among them they systematised the practice; they dealt with and solved technical difficulties; they developed rod, line, hooks and flies to their present excellence; and all that they acquired or invented was told to the world in sober and convincing English. Never was a reform worked out with greater ability or presented with greater lucidity.

Halford's first book, Floating Flies and How To Dress Them, was published in 1886, followed three years later by Dry-Fly Fishing in Theory and Practice. He wrote five others, the last in 1913, shortly before his death. Two of the seven deal with special subjects, fishery management and entomology, and of the five that deal generally with fishing and fly dressing the first two are by far the best. His later books are less good.

Halford's place in the history of fishing is well marked. He is the historian of a farreaching change, and as such it is probable that he will always be read. He was well-fitted for the task. He possessed a balanced temperament and a reasonable mind. He took nothing for granted, and proceeded by observation and experiment. He is the master too of a style 
suited to his theme, for while he never rises to great heights, he commands, in his earlier books, a prose which is apt and direct, and essentially his own. He established the dry fly as we know it. There have not been many changes since he wrote. Tackle has been refined still further, rod, reels and lines are if possible more excellent, flies are more closely copied and in particular the nymph and spent spinner are novelties. But the method of fishing is unchanged. You still have to find your trout rising or willing to rise, and to cast accurately and delicately. Halford's directions are as good and as useful as on the day when they were written.

If he is to be criticised it is because like most reformers he overstated his case. He considered that the dry fly had superseded for all time and in all places all other methods of fly fishing, and that those who thought otherwise were either ignorant or incompetent. He did not realise, and perhaps it is impossible that he should have realised, that the coming of the floating fly did not mean that previous experience and previous knowledge were as worthless as though they had never been; but that it meant that from then onwards fly fishing was divided into two streams. These streams are separate, but they run parallel, and there are many cross channels between them. Looking back more than a generation to Halford's first book, and taking note of what has happened, two tendencies are 
apparent. The floating fly has spread far beyond its original territory. When he first wrote it was the common but not yet the universal practice in a limited area; the chalk streams of Hampshire, Berkshire, Wiltshire and Kent, the Wandle, the Hertfordshire and Buckinghamshire streams, and the limestone streams of Derbyshire. Speaking generally, and without reckoning outlying areas such as Driffield Beck, Derbyshire was its northerly and Dorsetshire its westerly boundary. At his death, it had spread over all England, over Scotland, Ireland, and parts of France, Germany, Scandinavia, America and New Zealand; in fact, it was practised by some fishermen in most places where trout are to be found. It must not be imagined that wherever it went it conquered, for such was far from the case. But it won its way on rivers in which trout sometimes run large, such as Tweed or Don, and particularly in Irish rivers, of which the Suir is one. It has also come to be used more and more on lakes which hold big fish, such as Blagdon or Lough Arrow. And the new sport of fishing it for sea trout has been invented. Altogether Halford in the time between his first book and his death saw its empire spread over a large part of the earth.

That is one tendency to be noted, and very marked it is. But there is another, and that is the revival of the sunk fly, even on ground from which it was believed to have been 
banished for ever. This revival is due largely to the writings of Mr. G. E. M. Skues, whose Minor Tactics of the Chalk Stream was published in 1910. In this book he proves conclusively that the sunk fly has its use on the shyest chalk stream, that it will kill when the dry fly will not, and that it is a form of fishing as difficult and as entrancing as the other. It is an original book, and it is no disparagement. to its originality to say that it is founded on the wisdom of our ancestors. Mr. Skues is indebted to Stewart both for his method of fishing and of tying flies, a debt which he amply acknowledges. His great merit is that he has revived and brought up to date for use on chalk streams what was a lost art. He has rediscovered and restated it in terms suited to to-day. His book gives fishing a new starting point, and opens a new chapter in its history.

Since Minor Tactics appeared, there has been another noticeable movement, the use of imitation nymphs. The under water life of flies is much better known than it used to be, thanks largely to Halford, and the nymphs of the olive dun, the blue winged olive, the iron blue and the pale watery dun have been identified and are being copied. And these copies are not taking the form traditional to sunk flies, with head and tail, wing and hackle, but are being built on new lines, copying more closely the original. These are now being used extensively and with success on the shyest chalk streams. Whether 
ultimately they will prove more successful than the old and familiar sunk patterns is a point not yet cleared up. Many fishermen are convinced that they will: Mr. Skues, a most weighty opinion, thinks that they will not. Only a long trial can decide, and possibly the patterns of the future may be something different from either.

I do not want it to be supposed that these reactions detract from the dry fly's preeminence. They do nothing of the kind. In all the long history of fly fishing there has been no change so great as its introduction. Until it came we fished much as our ancestors did in the seventeenth century. Rods had been improved, certainly, but were in principle unaltered; the use of gut instead of hair had added a convenience : the invention of the reel modified the method of playing a fish; but the dry fly was more than all put together. It altered both the practice and the temperament of the angler. It called different qualities into request. It has a charm and an allurement which the older sport did not possess.

In what does its charm lie? Partly in the fact that all the moves in the game are visible. Just as a stalk is much more interesting when you can see your stag and watch his slightest movement, so with a fish. If you see him your eyes never leave him : if not, you watch for his rise. If it does not occur with its accustomed regularity, you have put him down. If you can 
see him, you watch every motion. Then you see your fly too. Nothing is hid. When the fly comes over him, you see him prepare to take it-or treat it with stolid indifference. You see him rise and take. The whole drama is played out before your eyes.

Then again you attack him when the odds are most in his favour. On a hot still day in June he is far more alert than on a blowing April morning. He has lost the exuberance of spring. The water is low and clear, and the surface unruffled. Weeds are thick and handy. Your gut must be the finest, your fly the smallest. He is hungry, it is true, but particular. Not only must your fly not fright him, it must please his lazy senses. When he pokes his nose at it and refuses, it may be that the reason is daintiness, not distrust.

His size too is an added attraction. No dry fly fishing is good where fish do not run large, and a big fish is a prize. Shooting gives no such trophy. You do not find one grouse three times the size of another, and if you did he would be easier, not harder, to hit. But the trout gets craftier as he gets bigger: his cunning grows with his girth.

The casting too has its fascination. On your day-and such days come to all of us, to make up for the many when we are either maddened or drugged and stupefied by our incurable ineptitude-how delicately and how surely you throw. You mean your fly to fall four inches 
above the fish, and sure enough it does, not an inch more or less. Nothing is too difficult: drag has no terrors : head wind is a friend, not an enemy, for does it not enable you to put a curve on your gut, which brings your fly over the fish first? You know exactly what to do, and you do it. Wherever the fish may be rising, your fly sails over him, hardly touching the water, wings up, floating like a cork, following every crinkle of the slow current. You gain an extraordinary sense of power. Your rod and line, right down to the fly, are part of yourself, moved by your nerves and answering to your brain.

So much has been written about the scenery and surroundings of fishing, that a late comer in the field is reluctant to embark on it : so much good there is to which he cannot hope to attain, so much bad into which he may easily fall. But, after all, scenery and surroundings can hardly be omitted, for I doubt whether anyone thinks of his great days without at the same time recalling not only the weather, which must always be a permanent part of the picture in a fisherman's mind, but also the scenery. You remember the look of the river, the green of the reeds, the wind blowing over the thick bed of sedges, the long line of rustling poplars. And while most rivers are beautiful, especially to him who follows the river and not the road, there is a quite particular charm about those of Hampshire and Wiltshire. It is hard to 
describe, but we all feel it, deep down in our beings. We may belong to the north, and would not belong elsewhere if we could; but when May and June come we are caught and swept by a longing for those gracious and lovely valleys, which is not satisfied till we go there.

In these happy valleys each season has a charm of its own. If you are so lucky as to be there in early April you have the added attraction that spring and summer are in front of you, five solid months of fishing. What matter if there be no rise? There will come days in May when the olives will sail down in fleets. What matter that you know that your total days in the year will be few? Never mind, you will have some: the glories of the summer are still to come, and you feel the same deep inflowing happiness which you experience when you are on the river early on a June morning and know that the whole long day is before you.

The valley early in April is quite different from its aspect in June. The willows are only just green, the oak and the poplar still bare. The dead rushes and sedges, washed by the winter rains, give the landscape a peculiar bleached look, and the water by contrast looks dark and rather forbidding. Not many flowers are out, but the kingcup is everywhere : in waste places where last year's reeds lie thick and yellow it glows beneath them like flame beneath firewood. The grass too in the water-meadows is the dark glossy grass of early spring, unlike 
any other colour in the world and quite different from the grass of summer. Ever since January the water has been let in to trickle among the roots of the herbage, and now when ordinary fields have not begun growing the watermeadows have a thick crop. The sheep will soon be penned on it and their busy teeth will eat every scrap down to the roots, until the field looks a faded yellow. Then the water will be run in again, and in June the haymakers will be at work.

As April runs into May, the valley changes greatly. It becomes green everywhere; so of course do other landscapes, but its special character is that it shews so many different shades of green, and shews them all together. The yellow green of the young willows, the bright green of the reeds, the blue green of the iris, the vivid green of some water weedsthese are seen simultaneously. But perhaps the chief cause of the valley's beauty is reflected light. Light is reflected at all angles off the glancing water, and gives the leaves an airy and translucent appearance, which you do not get elsewhere. May too is the month of the hawthorn, and thorn trees flourish particularly well on the chalk. Then also the birds come, and sedge and reed warblers make the banks musical. Opinions will differ as to whether May or June is the best month. May has the charm of novelty not yet worn off, but June has that of perfect fulfilment. And to the chalk- 
stream fisherman June is the best month of all, for who would not if he could choose a windless day in June? It is the month of the meadow flowers, and though the different shades of green are less marked and are merging into their summer sameness, the yellow iris makes the banks a garden, the wild rose stars the hedges, and the guelder rose hangs its cream-coloured lamps over the carriers.

As summer goes on and the rest of the world grows dry and dusty, the valley remains green and cool. Running water is everywhere: racing in a miniature trout stream by the road side; filling deep brimming carriers, rivers in themselves; trickling and percolating over the fields. The valley is a delight all the year, but perhaps it is never quite the same after the summer grass has been mown, for it loses something never regained, and you see signs that the best of the year is passing. Still, July and August have their attractions. A new set of flowers appears. The comfrey and the thick clusters of purple loosestrife and the golden mimulus may not equal the June flowers. They may not compare with the wild rose, the guelder rose, and the yellow iris, perhaps the loveliest of British flowers. But they are suitable to the time, and their solid colours fit in with hot days. July and August too are fishing months whose excellence is often overlooked. On late rivers such as the Kennet you get good fishing right into September. By August 
another feature of the valley appears, the Great Sedge is in flower. Until June the sedge forest is composed of the tall yellow stalks of last year's growth. The green shoots as they grow slowly push them off, but they remain late in the summer and it is not till August that the new growth is complete. Then they are a glaucous green, with feathery purplish heads, beloved of night-flying moths. The forest is as tall as a man, and so thick that you have to force your way through it.

As September runs to its end, some of the special features of the valley disappear. It becomes more like other landscapes; beautiful still, but less individual. If you like you can stay on for the grayling fishing and watch the trees take on their autumn colours. You can if you like. For myself I do not care to. So by September, if you take my advice, you will quit the valley, taking with you memories which will never leave you. Another year has passed, and you are lucky to have spent any of it by the river. You will not regret your 'idle time, not idly spent.' 


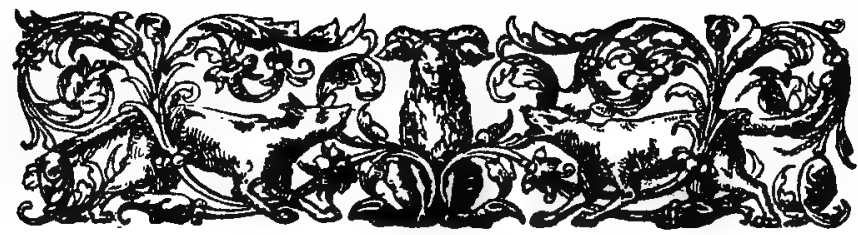

CHAPTER IX.

THE EVOLUTION OF THE TROUT FLY.

I.-THE MATERIALS.

And among the variety of your Fly-adventurers, remember the Hackle, or the Fly substitute, form'd without Wings, and drest up with the Feather of a Capon, Pheasant, Partridg, Moccaw, Phlimingo, Paraketa, or the like, and the Body nothing differing in shape from the Fly, save only in ruffness, and indigency of Wings.

Northern Memoirs, Richard Franck. 1694.

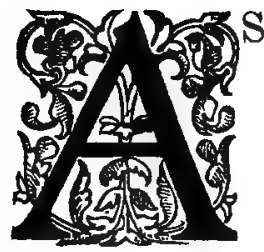

S I have said, fishermen when they cast their eye on flies and began to imitate them, proceeded on what we can now recognise as three distinct principles. Some imitated fly life generally, and produced an article which was a fair copy of an insect but could not be connected with any particular species or genus or group. Such flies are called fancy flies. They have many redoubtable advocates, drawn in modern times 
chiefly from Scotland. Stewart pinned his faith to his three famous hackles, his black, red, and dun spider. No doubt each of those could with a little laxity, be identified with a specific insect; but he did not set out to imitate such, and chose his flies with an eye rather to weather and water. This, in fact, is the feature which distinguishes this school : more attention is paid to light, to the clearness of the water, and to the sky, than to the insect. Stewart has many followers to this day.

The next school use what are called general flies, that is, flies which imitate a genus or a group, but not an individual. They differ from the last in that they regard imitation as more important than light or water: but they consider that precise copying is impossible, and, if it were possible, unnecessary.

The third and last is content with nothing short of an actual copy of the individual species which trout are taking. Of these was Halford, who when he first wrote included fancy and general flies in his list, but at the end of his long life says that his full experience convinced him that specific imitation is best in all weathers and all waters. Of course these three schools merge into each other. A fly can be more or less general, or it can be on the borderland of fancy and general, or of general and individual. Take the Partridge and Orange as an example. It is fished in the north all the year round, and may be called a fancy fly. But it is possibly 
the best imitation of the February Red, and when so used it is specific. And besides the February Red it also kills as an imitation of the nymph of the Blue Winged Olive, and as such is general. Or again the Wickham is regarded as a fancy fly, yet a trout must be keen sighted to distinguish it from a Red Quill, specific imitation of a Red Spinner. So there is no hard and fast line. Nor is there a hard and fast line with fishermen, for most of us use all three sorts. Few are entirely fancyists or generalists or individualists. Yet the distinction remains and has been an important one throughout history.

I do not propose to enter on that controversy, which has been waged with some acrimony. What I want to show, if I can, is man's struggle towards the light in specific imitation, how he found his way slowly to the exquisite copies which we use to-day. But before doing that there is one further distinction which I must mention. The individualists themselves are split into two schools, those who regard colour as the more important factor and those who regard form. Some, with Sir Herbert Maxwell, believe that a scarlet Mayfly kills as well as a natural coloured one. Others change their Olive Quill so as to match its hackle more closely to the legs of the fly which has just arrived on the water. On this controversy all I have to say is that I shall assume for the purpose of this chapter that imitation both of colour and of 
form can be no disadvantage, and that the closer we can get to nature the better. But as to what colour is to a fish and how it looks from under the water, I cannot do better than refer the enquirer to two striking books recently produced by Mr. Francis Ward, Marvels of Fish Life and Animal Life Under Water, which break ground hitherto unexplored. Also there is much new and stimulating matter in Mr. J. C. Mottram's Fly Fishing. With that I shall say no more.

The best way to realise the course of progress is to choose a few natural flies which must have been distinguished by fishermen from the beginning of time and to see how succeeding ages have copied them. I suggest that the following twelve form as good a list as any : February Red, Grannom, Olive Dun, Yellow Dun, March Brown, Iron Blue, Stonefly, Mayfly, Red Spinner, Black Gnat, Red Sedge and Alder. All these flies are easily recognised and well known. The entomologist might protest, and deny a separate entity to the Yellow Dun, but I should silence him by appealing to the universal though inaccurate opinion of anglers. The earliest list of flies is in the Treatise in 1496, which contains twelve flies, copied from nature, as I hope to show. Mascall in 1590 annexed it with little variation, and Markham about twenty-five years later copied Mascall, but in some notable ways improved and explained the dressings. Walton, however, 
disregarded Markham and reverted to Mascall, and from Walton the list, getting more and more corrupt, found its way into numberless books, until finally in $\mathbf{1 7 4 7}$ Bowlker did a public service by rejecting most of it, and from that time the Moorish Fly, the Sandy Yellow Fly, the Ruddy Fly and many others disappear from fishing literature.

The next list is Cotton's in 1676, original and good but very long, containing between sixty and seventy flies, hard to identify with natural insects. The fame of its author caused it to be pirated often, and many of the dressings survived a long time.

The third list is in Chetham in 1681 : not the one in the body of his book, which is merely copied from Cotton, but the one given in the Appendix to the first edition and, in the later editions, incorporated in the book. Chetham says that it was the list of a very good angler and came to his hands as he was going to press. It is a list of great interest and modernity, the first to mention starling as a wing material.

That concludes the seventeenth century. In the eighteenth, by far the most accurate and complete is Bowlker (1747), and from him we move straight to the nineteenth century and modern times. Ronalds and Theakston, both writing at the middle of last century, give wellknown lists, and so does Francis ten years later, and Aldam ten years later still. From him we come to contemporary writers, who are 
numerous and will be mentioned in their place.

There is one early French list, that in the Traitté de toute sorte de Chasse et de Pêche (1714). It contains five flies, of which one or two can possibly be identified; but I feel a doubt whether they were copied from natural insects. At the same time the dressings are given in some detail and seem to be original: at any rate, if they are pirated, I do not know the source.

\section{February Red.}

This is the Treatise's 'dun fly, the body of dun wool and the wings of the partridge.'* That is the dressing in 1496. It is the same to-day. The Partridge and Orange, dressed with a partridge hackle and a body of orange silk, is the imitation most commonly used between the Tweed and the Trent and kills hundreds of trout every year. So that fly has not changed at all in four centuries and a quarter. There have of course been innumerable dressings during the period, and the fly has been given various names. Markham called it the Lesser Dun Fly, dressed with dun wool and partridge hackle; and Cotton the Red Brown, dressed with a body of red brown dog's fur and wings of light mallard. Chetham, not in his book but in the remarkable list of flies in the appendix, calls it the Prime Dun, with a body

*Throughout this chapter I have modernised the spelling and punctuation of the Treatise, but made no other change. 
of fox cub's down spun on ash-coloured silk and wings from a starling's quill feather. Bowlker called it the Red Fly, and dressed it with a red squirrel's fur body, a red hackle and dark mallard wings: Aldam exactly like the Treatise, mahogany silk and partridge hackle. And so on, to modern times, when it is dressed with a body of orange silk and hackled either with partridge, grouse, or woodcock, according to the fancy of the writer. It is the same fly throughout. There can be no doubt about the identification. It is the first fly given in the list in the Treatise; and it is the first fly which greets the fisherman when the inhospitable winter is over. The earliest French list also gives a fly not dissimilar for the month of April : body of red silk, head green, and wings from a red hen.

\section{Grannom.}

It is doubtful whether the Treatise mentions the Grannom, and Chetham is the first to give an unambiguous account of it.

The difficulty about the Treatise is this. Here is the description of a fly given for July: 'The Shell Fly at St. Thomas' Day. The body of green wool and lapped about with the herl of the peacocks tail : wings of the buzzard.' I always considered that an excellent dressing of the Grannom : green wool body and a mottled buzzard wing could hardly be improved, but I ruled it out because of the time of appearance. 
The Grannom comes up in April and lasts about a fortnight : the dates of its appearance and disappearance are clearly marked. The Translation of St. Thomas of Canterbury is 7th July, and I consider the Treatise particularly accurate in dates, and I never saw a Grannom, or heard of one being seen, so late as that. So reluctantly I rejected it. But my scepticism was considerably shaken by finding that Ronalds both uses Shell Fly as a synonym for Grannom and also found the fly, or one like it, in trouts' stomachs in August; and in his fifth edition says that the Grannom if dressed buzz is a good fly all the summer months into September. Cotton gives the Shell Fly for July, but considers that it was taken by the trout for the palm that drops off the willow into the water, and other writers, who cribbed from the Treatise or Cotton, also give it. But it is one of the flies specifically knocked out by Bowlker, and I do not think it reappears till Ronalds resuscitates it. Ronalds, extremely accurate, says definitely that he found the fly in trout in August : and possibly there is a fly which appears then with a green egg-bunch like the Grannom. This difficulty illustrates the intolerable burden under which we fishermen labour in not having a good modern entomology. Halford's book is not satisfactory. It is the work of one who was a great fisherman but not a naturalist, and I do not think that anyone who is not could possibly succeed. And, apart from this, it suffers from two defects : it 
has no coloured reproductions of the natural fly, and its scope is too limited. It is of little use to the field naturalist, and his requirements should be the object to be aimed at. Leonard West's Natural Trout Fly and its Imitation (1912) is in many ways excellent. It has good plates. It is highly original. But it leaves out too much; for instance, it does not mention well-known flies such as the Grannom, Iron Blue and Blue Winged Olive. Ronalds wrote quite a marvellous book; but it is getting on for a hundred years old, and during that time entomology has been revolutionised. Cannot somebody give us the book for which we are waiting?

But to return to the Grannom. Chetham gives the first undoubted reference. He calls it by its common name of Greentail in the list of flies in his Appendix. Its body is from a brown spaniel's ear, the tail end of sea-green wool, and wings from a starling's quill feather. Bowlker dressed it with a body of fur from the black part of hare's face, ribbed with peacock herl, two turns of grizzled cock's hackle at the shoulder, and wings from a finely mottled pheașant's wing feather. $\mathrm{He}$ found it no advantage to imitate the green tail of the female fly. It is a well-known fly, for it comes up in vast numbers and is noticeable because of the so-called green tail of the female, really a bunch of eggs; consequently nearly all writers from the seventeenth century onwards describe 
it. Chetham's dressing is good, but is weak in the wing, which should be finely pencilled and not clear. Bowlker's is much better, and Francis gives a dressing which is not unlike it. Still the dressing has varied little in the two hundred and forty years since Chetham described it. Pritt in his Yorkshire Trout Flies (1885) gives a good modern dressing: wings hackled from inside a woodcock's wing or partridge's neck or under a hen pheasant's wing : body lead-coloured silk with a little fur from a hare's face and the lower part green silk. A hen partridge wing feather makes perhaps the best wing, and heron herl the best body. This is how Halford dressed the floating fly.

The Shell Fly is, I think, in the early French list. The following is a dressing given for July: Body of green silk, inclining to golden (tirant sur l'or), blue head, and wings of a light-coloured feather.

\section{Olive Dun.}

The duns are difficult. From the time of Cotton at any rate there have been two among many which occur in all lists, the Blue Dun and the Yellow Dun. Entomology admits the existence of neither, but will only allow of an Olive Dun and of the Blue Winged Olive. The Olive Dun varies greatly' in colour, from very dark to quite pale : and I assume the Blue Dun to be an imitation of the darker and the Yellow of the paler flies. 
The Blue or Olive Dun is, I believe, the second Dun fly of the Treatise: 'the body of black wool, the wings of the blackest drake, and the jay under the wing and under the tail.' That dressing is not easy to construe, and I suspect the text is corrupt. It is plain that the fly had a black wool body and I think wings from the quill feather of a drake: not the dark mottled feather, usually called dark mallard; for I think (though it is only a matter of opinion) that when the mottled feather, light or dark, is intended, the Treatise uses the word 'mail,' which would be an appropriate word for a body feather. So our fly has a black wool body and clear dark wings of a drake's wing feather : but what is the meaning of jay under the wing and under the tail? Does it mean a jay hackle run all down the body from wings to tail, and is this hackle the blue feather, or what is it? It is difficult to say. Markham, who corrected so many of the ambiguities of the Treatise, saw this difficulty, for he gives a dressing materially different : body of black wool and wings of the dun feathers of a drake's tail. That is plain enough, and both dressings are fairly good, though a little dark even for the Dark Olive. Cotton gives two Blue Duns, one for February and one for March, besides a Great Dun for February, the best fly for the month, giving admirable sport. $\mathrm{He}$ is therefore confusing, but as all three are so alike as to be practically indistinguishable, I take the dressing of the 
Great Dun, which is a body of dun bear's hair, and wings of grey mallard taken from near the tail. That is an improvement on the Treatise but still far from good. Chetham takes us further; he dressed his Blue Dun with the down of a water mouse and the blue dun of an old fox mixed together spun on ash-coloured silk, and wings of a starling's quill feather. That is getting on, and approaching the old mole's fur Blue Dun of my youth. Bowlker dressed it with a body of yellow mohair and blue fur of a fox mixed, a blue cock's hackle, and blue duck or starling wings. That dressing survives till to-day, if the duck wing as an alternative be dropped. Francis dressed it almost identically. In later years it was and still is dressed with mole or rat's fur body and a snipe wing, and these are the materials given in the late Mr. Tod's Wet Fly Fishing, and still later by Mr. Skues in Minor Tactics.

The progress of this fly is of extraordinary interest. It starts with a black wool body, dark mallard wings and possibly a jay's blue feather as hackle. This dressing is too dark altogether in body and wing. Cotton lightens both, and gives a fairly good fly, and Chetham a still better one. His Blue Dun has no hackle it is true, but its rough body of fox fur could easily be picked out, and except for this it is almost as it now exists. But there were one or two improvements, the snipe wing, which I think is better than the starling for the sunk 
fly, and mole's fur body. So we get the fly of to-day.

The dressing of Olive Duns as floating flies is different. The fur body absorbs too much water and the beautiful quill body we now use has taken its place. The hackle is usually a dyed olive one, though I doubt if it is any improvement on the old undyed dun hackle; and the wing is invariably starling, as Chetham discovered two hundred and forty years ago.

\section{Yellow Dun.}

The Dun Cut of the Treatise: 'the Dun Cut, the body of black wool and a yellow list after either side, the wings of the buzzard bound on with barkyd (i.e. dyed) hemp.'

The curious name of Dun Cut lasted till last century as a synonym for the Yellow Dun. It is common in the eighteenth, and Sir Humphry Davy uses it still later, and even in 1849 John Beever ('Arundo') gives it in Practical FlyFishing. I know nothing of its origin. Curiously enough it is not given by Mascall, who called it the Sad Yellow Fly, and from him the name got into Walton, who pirated from Mascall, and from Walton into the numberless writers who pirated from him, till finally Bowlker knocked it out of fishing books in the middle of the eighteenth century. By then it was corrupted to Sandy Yellow Fly. But though the Sad or Sandy Yellow Fly has disappeared, the fly as the Yellow Dun or Dun Cut has had a 
vigorous life. Cotton knew it as the Dun Cut, made of dun bear's hair mixed with some blue and yellow and a large dun wing. Chetham's invaluable appendix calls it the Yellow Dun, and he as usual produces a most modern fly, of yellow marten's fur dubbed on yellow silk, and a starling wing. Bowlker did not distinguish it from the Blue Dun. Best (1787) gives both Yellow Dun and Dun Cut, somewhat different dressings, the first almost identical with Chetham. Thus it comes down to the nineteenth century, when Ronalds finally rigs it up, as it is to-day : body either yellow mohair mixed with pale blue mouse fur, or yellow thread well waxed to give it an olive tint, light yellow dun hackle and light starling wing. The body of waxed thread is best, but it must be a particular golden olive colour. I have killed numberless trout with it, and when they are taking it they will look at no other imitation.

For the hackle fly nothing beats the Dotterel and Yellow. Aldam gives the best dressing and Pritt gives nearly the same: body yellow green floss, hackled with a feather from the outside of a dotterel's wing. It is, in my experience, a better all-round fly than the winged pattern given above. But on its day the winged dressing beats it.

This fly has changed less than the Blue Dun, because it started better. A black wool body with a yellow list down either side, light mottled buzzard wings and a head of black 
thread make not a bad fly. As usual Cotton improves it a little and Chetham much. $\mathrm{He}$ strikes the two notes of modernity, yellow dubbing spun on yellow silk and starling wings : Chetham's pattern in fact is like Ronalds' first imitation, minus the hackle. The hackle is perhaps an improvement, but dubbing well picked out is nearly as good. Finally Ronalds gives it a shape which no one wants to improve. Jackson followed Ronalds with little variation, and Francis followed Jackson, and so on till now. For the floating fly the Yellow Dun is merged in the Olive, with a quill body: and there are innumerable other dressings, often varying but slightly.

\section{March Brown.}

Not in the Treatise nor Cotton : I suppose it does not appear on the Derbyshire streams which Cotton fished, for Aldam only gives it in his Appendix. It is not included in the manuscript he edited. Not mentioned indeed till Chetham, who called it the Moorish Brown and tied it with wool got from between a black sheep's ears spun on red silk, and wings of a partridge's quill feather. Bowlker calls it the Brown Fly or Dun Drake and tells a lot about it : it used to be tied, he says, of a dun drake's feather and hare's fur, which he thinks not the colour of the fly. He made it of hare's fur ribbed with yellow silk, partridge hackle, and wing from either partridge or pheasant, 
presumably the quill feather. From then onwards it has had innumerable clothings, for it is mighty difficult to copy, but it is remarkable that Ronalds, writing nearly a century after Bowlker, gives what amounts to the same dressing, and many followed him. It is not easy to choose the best modern dressing, for there are so many, that everyone has his favourite, but I will take the one in Brook and River Trouting, of Edmonds and Lee, a good modern book: wings, from tail feather of a partridge, body orange silk dubbed with hare's ear fur and ribbed with yellow silk; hackle, the greyish feather from a partridge back.

I rather like Chetham's pattern, for black sheep's wool is brown when held up to the light, and if spun on red silk might give the reddish brown of the body which is so hard to copy. And then a partridge quill feather is good. The perfect fly is still to come, but meantime it is worth noticing how little it has changed in what is nearly two centuries and a half.

\section{Iron BLue.}

Chetham is the first to mention this also, and he made it 'of the Down of a Mouse for body and head, dubt with sad Ash-coloured Silk, wings of the sad coloured feather of a Shepstare quill.' He calls it the Little Blue Dun, but it is clearly the Iron Blue, for though he gives it as a September fly and it makes its first appearance much earlier, it lasts right into autumn and on 
some rivers is a typical autumn fly. I have seen it come down in fleets when fishing the Eden for salmon in October. Bowlker knew it well, and gives an excellent description, and is the first writer to say what is so true, that it is particularly abundant on cold, stormy days. Bowlker winged it with 'a Cormorant's feather that lyes under the Wing in the same form as those of a Goose.' I should like to see that feather. The body he made of mole's fur, or still better of water rat's, ribbed with yellow silk: and two or three turns of a grizzled hackle. The best dressing to-day for a sunk fly is water hen either for the winged or still better for the hackled fly, with a body of silk, either all purple or purple and orange. Or it may be composed of a dark snipe hackle with a purple silk body. Four variations, all good, are given in Pritt. For the dry fly nothing beats tomtit's tail for wings, whilst for body you can have either mole's fur or quill dyed purple. I always fancy mole's fur kills best. The hackle should be honey dun. This pattern, by the way, with mole's fur on claret silk, is given by that fine judge Mr. Skues as the best underwater pattern, but I should feel happier with a Water Hen and Purple.

Such is the fly as it is, and such was it at the end of the seventeenth century : how did it get from one to the other? It starts well, for a dark dull starling wing is good and so is a mouse fur body. In fact either mouse or mole's 
fur prevails to-day. The two improvements which have been made on Chetham are the substitution of tom tit's tail for wing, which gives just the right purplish colour, and the dun hackle. I am uncertain who first pitched on tom tit's tail. Wade in 1861 in Halcyon calls it the Little Blue Bloa and gives blue or black cap's wing, and I suppose the blue cap is the blue tit, and the black cap may be the tom tit. Ronalds in his first edition gives Bowlker's cormorant's feather, but as this is hard to get the tips of two feathers from a water hen's breast may be substituted; but in his fifth edition in $\mathbf{1 8 5 6}$ he gives as well the upper end of the wing feather of a tom tit when in full plumage. Francis mentions tom tit's tail in 1867, though he attributes it to Wade, which seems a mistake. So we must take off our hat to the shade of that mighty fisher himself.

\section{STONEFLy.}

This fly has changed neither in name nor in dressing. It is quite unmistakeable, a fat, stupid, clumsy clown, better at running than flying. The Treatise is as follows: 'The stone fly, the body of black wool and yellow under the wing and under the tail, and the wings of the drake.' Markham as usual makes the dressing more definite: the yellow under wings and tail is to be made with yellow silk and the wings are of a drake's down, not the quill feather. 
Cotton knew the fly well and gives an excellent account of its history: he made the body of dun bear's hair and brown and yellow camlet well mixed, making your fly more yellow on the belly and towards the tail, two or three hairs of a black cat's beard for tail, and long, very large wings of grey mallard. Though we use different furs from Cotton, his body survives unchanged in essence: but a hen pheasant's quill feather makes a truer wing than light mallard, and we like to add a hackle, either blue dun or greenish. But the changes are immaterial.

\section{MAYFLY.}

We get now on more debateable ground. The Treatise does not mention the Mayfly by name, and its identification is matter of conjecture. I believe, though I do not feel sure, that two dressings are given, one dark and the other lighter, just as they are used to-day, according as the fly is brown or light. I take the Maure (i.e. Mulberry-coloured) fly to be the first : it is, be it noted, given as appearing in June: 'The body of dusky wool, the wings of the blackest mail of the wild drake.' Dark mallard is still a favourite wing material. The second or lighter dressing is 'The Tandy (i.e. tancoloured) fly at St. William's day, the body of tandy wool and the wings contrary either against other of the whitest mail of the wild drake.' St. William's Day is 8th June, on 
many waters the date of the fly's appearance.

Now, if these two dressings are looked at, they are not bad. They stand comparison with those of admitted masters. For instance, Ronalds made the wings of light mallard, stained either olive or purple; and before and after him, from Cotton in the seventeenth century to Francis in the nineteenth, the common wing feather is light mallard, usually dyed pale green or yellow, but sometimes undyed. Undyed widgeon is also used : and it is worth noting that Markham used light widgeon set back to back. The dark brown mallard was less common, but was used by Ogden, who preferred undyed feathers, and plenty of flies with undyed mallard wings both light and dark are to be seen in the shop windows as I write. And note too that in one fly in the Treatise the mallard wings are to be tied on back to back, as they are to-day. So there is nothing wrong with the wings. As to body, it was made either of dusky or tancoloured wool. This is too dark, but not greatly so, for one of the very best mayflies that I know has the body of dark copper-coloured silk.

So much for the identification; and while it does not reach certainty, it amounts to strong probability. It is unlikely that so conspicuous and widespread an insect as the mayfly is not in the list; and, if it is, there is only one other fly which it could possibly be. That is a fly 
given for May and called the Yellow Fly, with a body of yellow wool, a red cock's hackle, and wings of the drake stained yellow; but that is so clearly and unmistakeably the Little Yellow May Dun that it can be rejected. So on the whole I believe the identification to be right. Mascall misread Maure and made it into More or Moorish : and as the Moorish Fly the fly got into Markham and Walton, and from Walton into those who stole from him: and Tandy or Tan-coloured similarly got corrupted into Tawny. Both names were slavishly copied into fishing books, until Bowlker knocked them out. Whether the identification of the Treatise's flies be accepted or not, there is no doubt that Barker knew the Mayfly. He made is 'with a shammy body ribbed with black hair' or with black sandy hog's wool ribbed with black silk, and winged with mallard. Cotton also knew and described it. He called it the Green and Grey Drake and gives a long and good account of the natural insect. He dressed the Green Drake with a light mallard wing dyed yellow, and the Grey Drake with undyed grey mallard, the darkest grey feather.

A whole book could be written on the dressings of the Mayfly alone. Until the middle of last century a mallard wing was almost universal; but it has now been largely replaced by wood or summer duck or Egyptian goose. Many other materials have been used : teal, Rouen drake, Guinea fowl, Andalusian 
cock hackles, silver pheasant's tail and many more : and for body, wools of all sorts and colours, quill, silk, tinsel, gut, straw, indiarubber, gold beaters skin, cork, goat's hair, grass, and numberless more.

\section{Red Spinner.}

'In the beginning of May a good fly, the body roddyd (i.e. ruddy) wool, and lapped about with black silk: the wings of the drake and of the red capons hackle.' Thus was the fly fished during the Wars of the Roses, and thus in all essentials was it fished during the Great War. 'Body, dark red brown silk, ringed with fine gold thread; legs, a red hackle; tail, three wisps of the same; wings, a dark shiny brown feather, the more brilliant and transparent the better.' This, it is true, is not quite modern, for it is the dressing given by Francis fifty years ago, but it prevails to this day, as can be seen by walking into any tackle shop. Is it not amazing that the fly should be unchanged during nearly five hundred years? It is a much more remarkable case than the Stonefly or Mayfly : that great blatant creature the Stonefly, forcing himself on our notice like an overgrown puppy, or that lovely and delicate lady the Mayfly, trimming her lateen sails to the June breezes, are too notable to be overlooked, and too clearly patterned for diversity of copy; but a slight indefinite insect like the 
Red Spinner, hard to determine and harder still to imitate!

Just consider the two dressings. Red wool dulled by a ribbing of black silk is indistinguishable from red brown silk brightened by gold thread : the basis of the fly, red hackle, is the same in both: the wings are not different. The fly is the same, in detail as well as in substance. And possibly no fly has had a wider range of use. Everywhere where trout are to be caught, the red cock's hackle will catch them. Mascall called it the Ruddy Fly, and as usual this was the name handed down. He says it is 'a good fly to angle with aloft on the water.' He was prophetic: its modern counterpart, the Red Quill, has floated aloft on many waters in many lands. That old writer of Queen Elizabeth's day has given us a sentence which might serve as the dry fly man's motto. Cotton dressed it with a purple body and red capon's hackle. Bowlker is the first to call it Red Spinner: he gives two patterns differing not a great deal from Francis : one of them has starling wings, anticipating the Red Quill of to-day. Theakston calls it the Orange Drake, with a body of orange silk, and an orange cock's hackle: Jackson the Red Tailed Spinner, winged from a landrail's quill feather: but it really is unnecessary to go on giving different dressings, for they are all alike. In modern times the fly has evolved into the Red Quill, with starling wings, quill body, 
and of course a red cock's hackle. This fly forms the foundation of dry fly fishing. It is perhaps used less universally than it was twenty years ago, but it remains the standard summer fly. Some fishermen use hardly anything else : it is one of Lord Grey's four flies, and is indeed included in every list : and it is the fly we should all of us put on when starting to fish unknown water. The number of trout that fall to it each year must be immense. The natural fly is of course the imago of the Olive Dun. The Red Spinner is certainly in the first French list: Dans le mois de May ils en font une, couverte aussi de soye, mais elle est de couleur rouge, et avec des filets tirans sur l'or : la tête en est noire, et on y joint les plumes rouges d'un chapon. That is to say, a red silk body ribbed with gold, which is precisely Francis's body: and of course, the red hackle.

\section{Black Gnat.}

Cotton evidently knew it well. He made the body of the down of a black water dog or of a young coot, and wings of the whitest mallard obtainable, the body being made as small as possible and the wings as short as the body. Two hundred years later, in spite of the dry fly revolution and innumerable changes, Halford made it not very differently : black quill body, cock starling hackle and palest starling wings.

The fly has three characteristics; a small body, transparent wings, and, in the male, 
particularly short ones. All these Halford allows for : he uses a thin quill from a chaffinch tail for body, and for wings the palest starling obtainable. And he notes, too, the short wings of the male. These three characteristics are the fly: and every one of these three Cotton observed and copied.

After this it is hardly necessary to trace the fly down. The commonest dressing, however, not I think the best, is black ostrich herl body, and either some sort of clear wing, or more usually wingless, with a dark or black hackle. So Bowlker dressed it : and so did Francis and many others. Nearly every writer agrees that it is a difficult fly to copy. It is a most unsatisfactory fly to fish with.

\section{The Red Sedge.}

Unlike all that have gone before, I do not think the Sedges were differentiated until quite late in history. Which is odd, for some of them, the Red Sedge for instance, are most noticeable. Theakston at the middle of the last century gives a good account of it, though in his tiresome phraseology he calls it the Red Dun. He winged it with landrail, brown owl, or red dun hen; body, copper silk; and hackle, red dun hen. Ronalds disregards it, though he gives a picture of the Cinnamon Sedge. Halford rejected it, and gives no dressing. On the other hand Francis thought well of it, and dressed it with a double wing, starling under 
and landrail above. The fly is used by some dry fly fishers, but is by no means universal, for many prefer, for the magic quarter of an hour when great trout take the Sedge, either a Coachman, large Red Quill, large Wickham, or Hare's Ear or Silver Sedge; and I am of that number. The large Red Sedge as dressed to-day has a white body of silk or wool, a reddish buff hackle run all the way down, ribbed the reverse way with gold wire, and full wings of landrail. For the sunk fly nothing beats a copper silk body, with landrail hackle at the head only. It is a great summer fly for day or evening fishing, dressed very small. For night fishing it becomes the Bustard, dressed immense, with a brown owl wing.

\section{The Alder.}

The alder may or may not be mentioned in the Treatise. This is the dressing of the only fly given for August: 'The Drake Fly, the body of black wool and lapped about with black silk; wings of the mail of the black drake with a black head.' Markham called it the Cloudy Dark Fly, and made it with a cork body covered with black wool clipped from between a sheep's ears, ribbed with black silk: head black: wings, the under mail of the mallard.

First of all, there is a point on the construction of the Treatise dressing. What is the meaning of 'mail of the black drake with a black head'? It may mean one of two things : 
either some specially coloured dark mallard feather, only to be found on a black headed drake : or black head refers not to the bird but the feather, and means one with a black or dark base. Every fly dresser knows that dark mallard varies greatly in colour, especially at the base, and many feathers with dark tips have a light root. You are therefore directed to choose a dark rooted one. This interpretation is conjectural, but it is not unlikely and makes sense.

Now, the living Alder has a black head, nearly black thorax, dull brown abdomen, and light brown wings with very strong brown veining. It is a well-known fly, recognisable at once from the downward set of the wings when at rest, which caused Kingsley to apostrophise it as 'hunchback.' It is clear at once that Markham's dressing is first class : wool of a black sheep has a reddish tinge when held up to the light, as we saw in the March Brown, and I believe would make a better body than the coppery peacock herl now almost universal. But be that as it may, there can be no reasonable doubt about the identification, for Markham certainly is describing the Alder. So I think, but with less certainty, is the Treatise. Black head, black wool body ribbed with black silk, and very dark mallard wings, make a good imitation, not very different from the one you and I fish to-day.

The dressing commonly used now is a body 
of coppery peacock's herl, black or rusty black hackle, and dark woodcock or hen pheasant tail wings. But I believe we should do better to go back to Markham's body, and indeed Mr. C. E. Walker, who published in 1908 a book of high originality and value, which is a special study of dressing flat-winged and penthouse-winged flies such as the Alder, made the body of very dark brown floss silk, which is not dissimilar.

The Alder may possibly be described in the earliest French list : it is made of the longest feathers of a peacock, head yellow, and winged with a pheasant's quill feather. If that means a body of peacock's herl, and I think it must, it is a good dressing.

So even if we cannot date the Alder from Henry VII.'s reign (though I think we can) at any rate he dates from James I., and has a respectable pedigree of three hundred years. $\mathrm{He}$ has changed little during those three centuries: so little, that it is not worth while recording the dressings, so minute are the variations. This conspicuous animal, easy to recognise and easy to imitate, is usually seen by fishermen either in the air or crawling up a. grass stem: it is never on the water, unless blown there on a windy day, and there it lies, kicking but helpless, an easy mark for the trout.

That finishes the description of twelve representative flies. What conclusions are to be drawn? How many of these twelve flies have 
a continuous history and from what date? It is for the reader to decide: I have given the evidence. I have tried to do this without either understating the case, or overstating it : the last error, the reading of modern facts into old language, is an insidious, a common and a corrupting one, and I trust I have avoided it. Trying to hold the balance level, it seems to me that of the twelve flies, five are described in the Treatise beyond any reasonable doubt: the February Red, Olive Dun, Yellow Dun, Stonefly and Red Spinner : two more, making seven, the Mayfly and the Alder, are almost certainly; and one more, making eight, the Grannom, is probably included. Of the remaining four, one, the Black Gnat, dates from Cotton in 1676 : two, March Brown and Iron Blue, from Chetham in 1681, and one, the Red Sedge, from the nineteenth century. Therefore of these twelve representative flies, eight were probably observed and copied by the author of the Treatise, whoever that was, in the fifteenth century, three originated in the seventeenth, and only one in the nineteenth. I can imagine no better illustration of the antiquity of fly fishing, and of its continuity. 


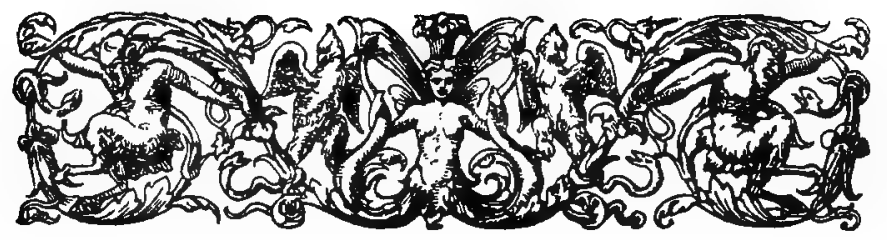

\section{CHAPTER $\mathrm{X}$. \\ THE EVOLUTION OF THE TROUT FLY (Continued).}

\section{II.-THE CONSTRUCTION.}

Now for the shapes and proportions of these flies, it is impossible to describe them without painting, therefore you shall take of these several flies alive, and laying them before you, try how neere your Art can come unto Nature by an equall shape, and misture of colours.

A Discourse of the Generall Art of Fishing, Gervase Markham. 1614.

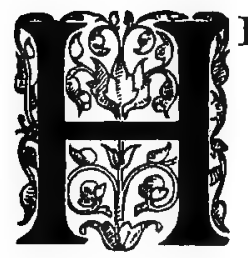

ITHERTO the road has been easy. It has not been difficult to show that from the materials used even in earliest times flies as good as those we use to-day could be constructed. It is much harder to prove that they were. And, without that, nothing is proved. You cannot judge the excellence of a painter from his colours and canvas alone, and fine marble does 
not necessarily produce a fine statue. What do we know about the actual fly used, the finished article?

It is not easy to say. There are no directions for fly dressing earlier than 1651, and no picture of an artificial fly earlier than 1620; and indeed then and for many years later illustrations are unreliable evidence; for the engraver's art lagged woefully behind the writer's. I do not know why, but the French, who produced inferior fishing books, produced infinitely better illustrations. If you compare the clumsy and puerile plates of fish in the Compleat Angler with the beautiful illustrations of the contemporary Ruses Innocentes you move into a different world; and yet the fishing letterpress of that Inventive Solitary, Frère François Fortin, is two hundred years behind Walton. And even in Venables, whose frontispiece contains excellent pictures of the fisherman's rod, reel and basket, the flies depicted are drawn roughly and inconclusively. So we have to rely on inference, and somewhat on conjecture : but we can perhaps find out something of what the old flies were, if we walk warily with our eyes open. We have four classes of evidence: the materials used, hooks included: the directions for fly dressing: the illustrations, for what they are worth: and such evidence as exists of the study of natural flies.

The Treatise gives no directions, but it does 
give us something of value, for in addition to the materials discussed in the last chapter, it has a plate of hooks showing their sizes. I think the plate can be accepted as accurate: those in the Treatise are either very good, like the excellent one of tools for hook making, or very bad, like that of the rod : and I believe this is one of the good ones. The great thing it proves is that hooks were not large. They vary. from 2 or 3 to 15 on the modern scale, and moreover are notably short in the shank. That argues a small fly. That is as far as we can go. But it can be added that the fact that flies were copied from nature, and the general excellence of the materials, make it probable that the construction of the trout fly did not lag behind.

Markham in 1614 went a little further. $\mathrm{He}$ cannot, he says, describe the shapes and proportions of flies without painting: therefore you are to take live flies, and copy their shape and colour as closely as you can. That again looks like well-made flies, for both shape and colour are to be copied. Then in 1620, in Lawson's notes to the Secrets of Angling, occurs the first picture of an artificial : but that does not help. It resembles nothing so much as a housefly on a hook. I cannot believe that that admirable angler used anything so inartistic.

So we really know very little till we reach Barker, the first to describe how to tie a trout fly. Cut off your wing material, he says, and tie the feather on the top of the hook, pointing 
away from the bend: strip one side of your hackle and tie it and the body and ribbing material in at the bend: make your body, run on your tinsel and make fast under the wings: turn your hackle and make fast. Divide your wing with a pin into two, whip between with a figure of eight, then with your thumb press the wings over towards the bend of the hook and take two or three turns of silk to keep them in place.

This, the earliest description, makes what we now call a reverse winged fly: the wings are originally tied on pointing the opposite way to the one they will finally adopt, and are got into position by being pressed back and the butt of the feather lashed down with two or three turns of silk. Venables, who dressed his flies in the same way, gives reasons why he did so. If he did not, he says, the action of the stream would fold the wing feathers round the bend of the hook, if the fibres are soft, as they should be. Also I think, though he is somewhat obscure, he believed that this method made the fly swim with the hook point well up, and not hang tail downwards: and therefore, he says, the action of the stream will carry the wings into the position of an insect when flying.

Venables' directions are much more detailed than Barker's. He tells how to make jointed bodies and bodies with different colours arranged lengthways: how to dress a hackle 
fly : how to put on tails or horns : and how to make a herl body. Imitate the underpart of the natural fly, for that is the part of your artificial which trout see : if you copy the back, you will have a too 'Orient colour.' Wet your body material before matching the fly, for water alters its tint. The directions are detailed and good, and the impression left on the mind is one of skilled fly dressing.

Cotton's directions, a few years later, are not very different. He too started by tying on the wings, reverse way. You should not carry the body beyond the bend of the hook, as you do in London, says he slyly to his pupil. In London, answers the pupil, we make the body bigger than you do and also longer, almost to the barb. I know you do, Cotton retorts: an honest gentleman who came with my father Walton gave me a fly like that, which, to tell the truth, I hung in my parlour window to laugh at. So here again is evidence that Cotton's flies at any rate were slender and short in the body. And here too is proof that southern flies were fatter than northern, as they are to this day.

Barker, Venables, and Cotton between them give a fairly complete code. Their flies are, it is true, of two types only, either hackled, or with reverse wings, set on the top of the shank. The feather too was a single strip tied on first and then divided, for they did not make their wings as they are made now, from two slips 
taken from right and left-hand feathers. Nor did they give any particular set to the wings of flat-winged flies, such as Stoneflies or Alders, but apparently tied them on at the same angle as those of Olive Duns. In this indeed their successors did little better, for the Alders and Sedges in Halford's first book have practically upright wings, and so they have in tackle shops to-day. It is extremely difficult to get Alders with wings tied at the proper penthouse angle, in spite of Mr. Walker's valuable book.

The common way of dressing during the eighteenth century also was reverse winged. Bowlker gives it in 1747, and Bowlker was the standard authority for over a century. Indeed there was little change before the middle of the nineteenth century. It is of interest to compare the directions in Barker, Venables and Cotton with those in Blacker, two centuries later. I am referring to Blacker's third book, the Art of Fly-Making (1855). In it he gives the reverse winged fly as the first and easiest pattern; all his directions are very like the earlier writers, with the important difference that his wings were made of two slips. $\mathrm{He}$ also gives directions how to wing the other way; but anyone reading the two accounts together will not find much difference. Ronalds, however, and Stewart, and I think most nineteenth century dressers before dry fly days, tied on the wings so as to face the bend of the hook. 
Thus down to Bowlker in the middle of the eighteenth century wings were composed of a single strip, tied on in a bunch and divided. This developed into the rolled wing, made famous by Stewart, and in general use to-day. The material is cut from a single feather, folded into several folds with the lightest coloured side outside, tied on in a bunch at the top of the hook and separated into two by tying silk in a figure of eight. Mr. Skues, pondering on Minor Tactics and casting his eyes round for the best dressing of sunk flies for chalk streams, unhesitatingly pitches upon this.

Leaving flat-winged flies on one side, there are therefore two ways of constructing wings and two ways of tying them on. They can be constructed of a single piece, put on either single or rolled; or they can be made of two slips. They can be tied on either the natural way or reversed. The earliest form was the single strip, tied on reversed.

Cotton apparently did not hackle his winged flies, but, as his bodies were always of dubbing, this could be picked out. Barker recommends hackles, with one side stripped, either cock or capon, or plover's top which is best. Venables used a hackle or none, indifferently. All made their bodies of fur, or wools, and since the brightly-dyed wools which we use were not obtainable, they had to get a rare collection, bear's, heif'er's, dog's, fox's, and what not. 
The body of floss silk did not come in till later. The detached body, such a favourite with early dry fly fishers, but now rarely seen, is first described and figured by Blacker.

During the second half of last century fly tying differentiated. It was realised, slowly at first, that sunk patterns would not do for floaters, and still more slowly that floaters were little use sunk. Who first dressed a fly to float is uncertain, but both Ogden of Cheltenham and Messrs. Foster of Ashbourne were selling them in the fifties if not earlier. The first directions are in Ogden's Fly Tying in 1879. Seven years later Halford's Floating Flies came out, far in advance of anything seen before: it was and remains the standard work. Since then many admirable books have appeared, and the dry fly has been specialised more and more, until we get the exquisite creations we use to-day. Specialisation, too, has not only produced flies differing from sunk patterns : it has gone further, and the different sexes and states of the natural insect are also copied. Instead of being content with the old Blue Dun and Red Spinner, the modern fisherman must have his Olive Nymphs, his Olive Duns male and female, his Red Quills and his Spent Olives of either sex. And I am bound to say that there is a use for all of them. Nor have sunk patterns been neglected. Much has been done, and it is to be hoped that Mr. Skues, who knows more about underwater happenings 
than most of us, will one day give us the result of his experience.

So much for fly dressing; now for pictures. The earliest, in Lawson's notes to the Secrets of Angling (1620) tells nothing, for it is clearly a stock illustration, made by someone who knew less than nothing of fishing. Nor are the next any better, those on Venables' frontispiece. If we are to go by them, his flies were clumsy and wingless, with fat bodies and sparse hackle; but I hardly think that much reliance can be placed on them.

In fact there are no illustrations of any value until the end of the eighteenth century. At that date there is a plate in Sir John Hawkins' edition of the Compleat Angler (it is in his fourth edition of 1784 and no doubt also in his first of 1760) and there is one not unlike it, copied from it I suspect, in Best's Concise Treatise of 1787. Some contemporary editions of Bowlker also have the same flies, all possibly from the same source. Six flies are figured in Best, for example, two hackled and four winged, varying in size from the Green Drake to the Ant Fly. They are large and clumsy, but not over-winged or over-hackled, and probably we must take them as typical. I think, however, that Cotton would have had another laugh at their portly bodies.

The first artistic picture of artificials is in 1826. An edition of Bowlker appeared in that year with an admirable coloured plate of thirty 
flies. For the first time illustration keeps step with letterpress. The flies, though some sizes bigger than I should care to use to-day, are delicately made, light in hackle, slender in body and thin in wing, and at last represent the equipment of a modern fisherman.

Bowlker was precursor to a greater than he. Ten years later Ronalds produced his wonderful book. This gave coloured plates of natural and artificial flies, the naturals all classified and named. Few books have been more widely read, or had more influence. It went through eleven editions, the last, a sumptuous one, coming out as late as 1913. It started a school of writers and a school of thought. Though nearly one hundred years old it remains the only book of its class, and the world is still waiting for the benefactor who will bring it up to date. It is the textbook and in a sense the creator of the race of angler-naturalists.

In giving coloured plates of natural and artificial flies, though far superior to anything that preceded it, the book is not original. Bowlker anticipated it in plates of artificials; whilst there were several writers before Ronalds who studied nature, and a few who gave figures of natural flies. So it is here necessary to go back for a bit and to see how fishermen first recorded their observations of living insects.

Ronalds is the father of the modern angler- 
naturalist; Taverner, if he had not been so strangely neglected, might have filled the same office for an earlier age. John Taverner was Surveyor of the Royal Woods on the South of the River Trent for King James I. He published in 1600 a book, original and rare, called Certaine experiments concerning fish and fruite. It is full of observation far in advance of his time: if Walton had read it, that great man would have avoided certain fantastic theories concerning the generation of pike and eels. Perhaps the most remarkable thing in the book is an accurate description of the migration of the eel, which has puzzled naturalists to this day. Indeed it is only in this year 1920 that the actual breeding place has been discovered, far off in the West Atlantic, south of the Bermudas. Hither, in the depths of the sea, eels from all Europe repair to breed, and when they have bred they die: and hence every spring come the elvers, crossing an ocean they have never traversed and bound for lands they have never seen; until, guided by some force of which we know nothing, they repeople the rivers, the streams, even the very ponds from which their parents departed. Few stories in natural history are so entrancing, few contrasts are so poignant, as that of the eel; which in its infancy crosses three thousand miles of ocean and forces its way up rivers and streams and ditches in order that it may spend its life in the agreeable mud 
'of some pond in England, in France, or in Italy, shaded by elm-trees, haunted by slowmoving cattle: and, after living there, and growing fat in peaceful ease, returns by the stormy road. which it travelled, and fulfils its long last journey, to reproduce and to die. Taverner did not know all this, but he knew much which others did not, for he says that eels undoubtedly breed in brackish or sea water, which no one else knew till centuries later.

He knew much about flies, too; he did not believe that they were bred from mud, or corruption, or may-dew, or any other of the fairy stories then prevalent; for this is what he says : 'I have seene a young flie swimme in the water too and fro, and in the end come to the upper crust of the water, and assay to flie up : howbeit not being perfitly ripe or fledge, hath twice or thrice fallen downe againe into the water: howbeit in the end receiving perfection by the heate of the sunne, and the pleasant fat water, hath in the ende within some halfe houre after taken her flight, and flied quite awaie into the ayre. And of such young flies before they are able to flie awaie, do fish feede exceedingly."

Taverner was probably more read by his contemporaries than by later ages, who have so strangely neglected him. Samuel Hartlib, in his well-known Legacy of Husbandry (1655-the

\footnotetext{
* It was Mr. Turrell who I think first called attention to Taverner, in Ancient Angling Authors; anyhow $I$ am indebted to him for it and for much else. Bibliotheca Piscatoria mentions Taverner, but gives no idea of his importance.
} 
third edition, the only one I have seen) quotes him as an equal authority on fishponds with Dubravius, high praise from a writer of that date. And, by the way, Hartlib, though he knew Taverner, had never heard of Markham or Barker (he could hardly have heard of Walton), for he laments that there is no good treatise on angling in English.

Though Taverner does not actually describe the splitting open of the ephemera nymph and the birth of the subimago, he comes near it. Cotton, an acute observer, knew a good deal, but he knew less than Taverner. He tells us much about the Stonefly and Mayfly, though he is wrong about their underwater life, for he imagined they came from caddises. It is odd that he should not have identified the Creeper. Still Cotton, though inferior to Taverner, was a fair field naturalist and knew the dates of appearance of the different flies. From Cotton knowledge gradually progresses. It was of course handicapped by the absence of good scientific works. I suppose the Theater of Insects by Dr. Thomas Moffett, published with Topsel's History of Fourfooted Beasts, 1658, is a fair type of current entomology. Its author, whose name is also spelt Muffet or Moufet, was a celebrated doctor, and an acute observer of insects; but in spite of this, and in spite of quite good illustrations, one of which I take to be a mayfly, the book would assuredly not be much help to the eager and perplexed fisher- 
man. He had to depend on observation, for books were either wanting or misleading; until Linnaeus rebuilt natural history. So progress was slow. By the time of Bowlker, a century after Walton, knowledge had moved little. Bowlker himself gives a most excellent and accurate account of the two transformations of the Mayfly: and about other flies, too, he has some useful notes. But it was not till the publication of the writings of Pictet, the Swiss naturalist, in the first half of last century, that the needed stimulus was given. There was some stirring of the waters before this, it is true, but of a rather unscientific kind. Hawkins' edition of the Compleat Angler gives a print, uncoloured, of a fly and of caddis cases. About 1800 there came out Scotcher's Fly 'Fisher's Legacy, a remarkable little book in many ways, chiefly because it is the first to give coloured figures of natural flies. He gives the February Red, Blue Dun, March Brown, Grannom, Mayfly, Black Gnat and others. They are drawn and described from original observation, and though there are some careless mistakes, such as giving the Mayfly eight legs, it is a good book. He wrote it, he said, because he found it impossible to recognise flies from the descriptions in books.

After Scotcher there came two other writers before Ronalds, Bainbridge, who wrote the Fly-fisher's Guide in 1816, and Carroll the Angler's Vade Mecum in 1818. Bainbridge 
is the best. His book went through four editions, of which the last came out after two editions of Ronalds' had been published. It contains five plates of natural flies, fairly well drawn, and coloured; it was a popular and reliable handbook; and it would have had a longer life had it not met a work of genius in Ronalds. It is well worth looking at, even to-day.

Carroll's book is a curiosity. Though published after Bainbridge, it is most inferior : it contains the portentous number of one hundred and ninety-four flies, none with scientific names, very few with popular ones, and most with quite inadequate descriptions, roughly drawn and as roughly coloured by hand. I suppose most collectors have a copy in their library but that not many look at it twice. I will only say this, that if you do take the trouble to wade through the crudities of the drawings, as I have had to do, it is just possible to identify the flies. The pictures are not quite so wild as they seem. Perhaps Carroll was the victim of his illustrator. At any rate the book was a failure; it was never reprinted, nor is it likely to be.

Ronalds is entirely original, and owes nothing to Scotcher or Bainbridge or Carroll. His book is both scientific and popular. $\mathrm{He}$ took trouble to identify his insects and give them their Latin names (not always correctly, it is true, and of course according to the science 
of his day, now largely obsolete).. At the same time, for the unscientific, he gave exquisite pictures, an example which Halford might have followed. They are, in a well worn phrase, works of art : it is difficult to imagine better pictures of the mayfly, for instance. Nor of the mayfly alone. All are good, and have the important quality of making the living insects easily recognisable.

Ronalds was followed on two lines. Some good books with plates of flies appeared, which would either not have existed at all or would have been done much less well had the Entomology never been written. If anyone doubts this, let him compare the rough and inadequate plates of flies, natural and artificial, in Salmonia published only a few years before Ronalds, with the beautiful and accurate illustrations in the books which followed him, such as Wheatley's Rod and Line, Theakston's List, Jackson's Practical FlyFisher and Wade's Halcyon. Identification and illustration have passed out of the hands of the amateur into those of the expert. There were good naturalists and good engravers before Ronalds, certainly; but he raised the

\footnotetext{
* The fifth edition of Ronalds in 1856 and some later ones were edited and revised by Piscator, whom Mr. H. T. Sheringham has conclusively identified as Barnard Smith, author of the well known arithmetic. Smith modernised the nomenclature. Pictet's work on the Neuroptera, in which the Ephemeridæ are included, began to appear in 1842, six years after Ronalds' first edition, and was completed in 1845. It would therefore have been available for Smith in 1856 .
} 
general standard so high that a writer of Sir Humphry Davy's eminence, had he lived after him, would have been slow to encumber his book with such artless productions. From henceforth the engraver keeps pace with the writer.

But Ronalds started another stream also, the angler-naturalist: in this his influence acted more perhaps by permeating all writers than by inspiring individual books. Still there were such. Chalk Stream Studies owes much to him. Kingsley indeed could have written a great book for the angler-naturalist. And Hamilton's River-Side Naturalist, too, is a book which might be better known than it is.

Of one of the latest of the books describing the natural fly, Halford's Dry Fly Entomology, something has been said already. Its author, a distinguished and devoted fisherman, gave much time and work to the book; and he was helped by his friends. The scheme of the book is in advance of Ronalds, as may be imagined, seeing the strides entomology had made. It attempted to give a life history of the better known insects in all their stages, from egg to imago. I will only here say two things about it : first that it should be read in its revised and improved form, not in the original book of 1897, but in the reissue in 1913 in the Dry Fly Man's Handbook. Secondly that though it contains much for which the fisherman is grateful, he is still impatiently expecting something more: something which really shall give 
him a modern scientific work on those flies on which his happiness depends. It will not be an easy book to write, for it must be the work of a naturalist. It will not be a cheap book to produce, for it must have really good coloured plates. But it will earn for its creator present gratitude and future immortality. Mr. Leonard West has attempted this. He has laid a foundation on which much may be built. His present book is incomplete, and his identifications difficult. It is to be hoped that the second edition, which is now promised, will carry the matter further.

There exist to-day many books with excellent representations of artificial flies-so many and so well-known that it is unnecessary to name them. Halford's first and best book, Floating Flies, is admirable. But one further method of representation should be noticed, that of books in whose pages there are inlaid actual artificial flies themselves. There are several such. I believe that some of Blacker's books are thus embellished, though I have never seen one. Sir Herbert Maxwell's edition of Ronalds is of this character, and so is the edition de luxe of Halford's Dry Fly Man's Handbook. But the best of all, for beauty and interest, is Aldam's Quaint Treatise. The flies in it are tied with an excellence that I have never seen beaten; and, as well as complete flies, all the materials of which they are made, silk, wool and feathers, are there displayed. 
Finally, as the latest repercussion of the influence of Ronalds, there is American Trout Stream Insects by Louis Rhead, which has just appeared. It contains a series of coloured prints of natural flies and some photographic reproductions of artificials and of other lures. The naturals are not identified or classified; and the nomenclature adopted is that of Theakston, a great drawback for British readers, among whom Theakston's names are confusing and obsolete. But in spite of all this, the book is invaluable. It contains coloured pictures of over ninety insects painted by the author: and though he tells us that the book represents seven years' work he should be well repaid by the gratitude he has earned.

That finishes the subject of flies. They have been followed for over four hundred years, and an attempt has been made to trace their development. There seems to me to be three conclusions to be drawn. First, from the beginning of things, flies were imitated from natural insects; every fly in the Treatise I believe to be such. Imitated clumsily, it may be, but still imitated. The next point is that, on the whole, the imitation was good, in view of the materials at hand. In Henry VII's reign fishermen were restricted to the homely products of the farm, the field and the forest : in our day the whole world has been ransacked. We, who have foreign materials available, have an advantage not possessed by earlier dressers. 
But the point to realise is that in cases where we still rely on home products, we use the same materials as did Dame Juliana: and therefore her flies have stood the test of four centuries and the competition of five continents. The February Red, made of partridge hackle and orange wool or silk, will be fished next March as it was fished four centuries and a quarter ago : the Red Spinner is dressed almost identically by Dame Juliana in the fifteenth century and by Francis in the nineteenth. For both we still use home-grown materials. But compare these two flies with the Mayfly, where we do not. Your Tudor ancestor made it of brown wool plucked from a heifer or a red deer, with wings from the common wild duck. You, when you set out next June, may take with you one whose wings are of the Summer Duck which comes from America, or of a goose which comes from Egypt, dyed with chemical dye whose ingredients come I know not whence: whose hackle is of Golden Pheasant which comes from China, and whose body is of maize straw which comes from Italy, or of indiarubber which comes from Africa. It is in these flies that there have been the greatest changes: in the others there have been few. No stronger proof could be given of the merits of the Treatise. Lastly, I find it impossible to believe that the author of the Treatise originated all the dressings described in it. When I think of the difficulties of imitation, of the many trials and 
failures which must precede success, I am compelled to the conclusion that the Treatise embodies a long previous history. This history may be traditional. It is possible that the author gathered all the knowledge displayed in the book from word of mouth and that she records traditions handed down through generations of anglers. This may be so. But I think it more likely that the written word existed as a guide. That we shall ever find any earlier manuscript is perhaps unlikely, but the possibility is alluring. I like to think that there is a chance, even the remotest, that some day we may have revealed to us dressings of flies even earlier than those which date from the Wars of the Roses. 


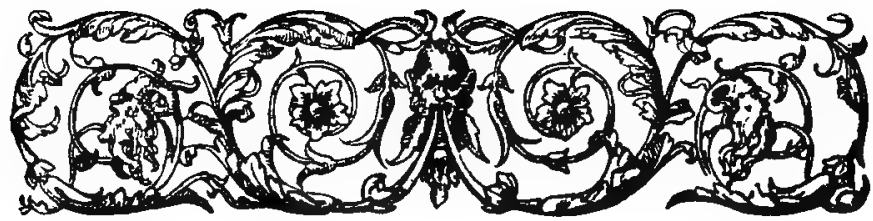

CHAPTER XI.

CONCLUSION.

THE LITERATURE OF FLY FISHING.

And now we are arived at the last,

In wishéd harbour where we meane to rest;

And make an end of this our journey past;

Here then in quiet roade $I$ think it best

We strike our sailes and stedfast Anchor cast

For now the Sunne low setteth in the West.

Secrets of Angling,

John Dennys. 1613.

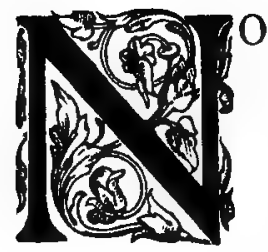

sport has a finer literature than fishing, and no part of that literature is finer than that devoted to the fly. From the earliest times fishing has never lacked writers who can express themselves; and fly fishing especially has frequently had much more, for authors of outstanding repute have written about it, both in prose and verse. Something has been said of these famous ones in previous chapters, and indeed their writings are generally known. Apart from Walton, who is known by name at 
any rate to every household, most people have heard of Cotton, of Gay, of Sir Humphry Davy, of Stoddart, of Colquhoun, of Andrew Lang, of Halford and of Lord Grey. But there are many lesser men who are not known even to fishermen, and they are not less interesting. Indeed, they are worth study even more than the greater ones; for they have not their facility, and yet they often have much to say.

Fly fishing springs from a splendid source. The author of the Treatise, whoever that may be, was fortunate in being able to draw on the noble model of French and English sporting books. The Treatise too was fortunate in the time of its birth, for it has all the clarity and directness of fifteenth century English. Our language had not then reached its full summit and sweep: it was to gain in flexibility and variety and colour; but among the prose of plain narrative, which can on occasion rise to beauty and dignity, the Treatise stands high. Do not take fish out of another man's gins or fish-traps, for that is not only stealing, but robs you of your sport : it "shall be to you a very pleasure to see the fair, bright, shining scaled fishes deceived by your crafty means and drawn upon land.' When you go fishing, too, 'you will not desire greatly many persons with you, which might let you of your game. And then you may serve God devoutly, in saying affectuously your

*Throughout this chapter I have modernised the spelling and punctuation of the Treatise, but made no other change. 
customable prayer. And thus doing you shall eschew and void many vices; as idleness, which is principal cause to enduce man to many other vices : as it is right well known.'

Leonard Mascall, who wrote a century after the Treatise, but who since he stole from it belongs to the same literary epoch, is chiefly known as a writer on fruit trees and vermin traps. I gather that his horticulture was good, from the extent to which it was pirated. Thomas Barker, who wrote on gardening as well as fishing, stole Mascall's chapter on grafting, which was unkind of a brother angler. However, as Mascall himself borrowed from the Dutch, and as he also robbed the Treatise, he has no cause to complain. Mascall was a fly fisher; but above all a fish preserver. There are many in this realm, he complains, 'that spares no time to kill, nor cares for no time to save, but takes at all times, which maketh freshe fishe so deare, and so scant in rivers and running waters.' Samuel Hartlib, fifty years later, a well-known writer on agriculture, friend of Milton, Evelyn and Pepys, says the same. Fish are scarce because nets are used with so small a mesh as to destroy the fry : and also because of a disgusting practice, which fortunately is obsolete, of feeding pigs on the fry. But to come rather nearer fly fishing, from which this is a digression, Hartlib quotes a writer on Ireland who imputes the leprosy of the Irish to their brutish eating of salmon 
when the very eye would have made them know they were unwholesome. The English therefore forbade the taking or selling of unseasonable salmon, which stamped out leprosy. One wonders, however, whether the prohibition was enforced in the interest of the Irish peasant or of the English fly fisher.

It is not until the seventeenth century that the literature of fly fishing reaches its height. Lawson, an early writer of that period, gives us a tantalising glimpse of what he might have done, had he devoted himself to fishing instead of gardening. His notes on fly fishing have been quoted. Admirable as they are in matter, they are too staccato and telegraphic in form to do justice to his prose. But listen to this, from his New Orchard and Garden; Walton might have written it. 'One chief grace that adornes an Orchard, I cannot let slip : a brood of Nightingales, who with severall notes and tunes, with a strong delightsome voyce out of a weak body, will bear you company night and day. She loves (and lives in) hots of woods in her heart.' That is surely an apt and beautiful phrase : she loves hots of woods in her heart. It brings to our mind early May, and innumerable nightingales answering each other in Kent or Surrey copses. And again, take Lawson's description of bees. 'Store of Bees, in a dry and warm Bee-house, comely made of Fir boards, to sing and sit, and feed upon your flowers and sprouts, make a pleasant noyse and 
sight. For cleanly and innocent Bees, of all other things, love and become, and thrive in an Orchard.' I would that he had written a fishing book. In the little which he wrote on the fly there is that intangible something which puts him among the mighty : indeed, if I do not exaggerate, he stands as high as any. And these quotations show that he could read nature and describe her. He might have written an angling book for which collectors would be scrambling.

Markham was in close alliance with Lawson, and their books were published together As a writer he is colourless. However, either he or whoever wrote the fly dressing section of his book put original work into it. But he also used grosser baits, and you are told to use 'in September either Cherries, Mice before they have any hayre, or the great Sow-worme.' The trout of those days must have been coarse feeders. I should feel no confidence if I had on a hairless mouse.

We now reach Walton and the golden age. I have already been rash enough to express an opinion of him: now for a specimen of his prose. I will take a passage which, though often quoted, is appropriate, for it tells of the only day's fly fishing: 'My honest Scholar, it is now past five of the Clock, we will fish till nine, and then go to breakfast: Go you to yonder Sycamore-tree, and hide your Bottle of drink under the hollow root of it; for about that time, 
and in that place, we will make a brave breakfast with a piece of powdered Beef, and a Radish or two that I have in my Fish-bag; we shall, I warrant you, make a good, honest, wholsome, hungry breakfast, and I will then give you direction for the making and using of your flies.'

I chose that passage because it shows Walton at his best, and shows how hard he is to follow. Charles Lamb says that the meals in the Compleat Angler give you an immortal hunger. And truly we long for nine o'clock to arrive on that May morning, so that we can sit under the sycamore tree and taste powdered beef and a radish or two. But the passage also illustrates the difficulty of imitating Walton. It looks so easy; a homely scene, told in simple words. It is only when you have seen it tried that you realise the difficulties. It is this side of Walton which has led his admirers to such hopeless grief.

But to come back to the sycamore tree. Whilst they are at breakfast, they leave their rods in the water. The Scholar finds a fish on his, but is broken. Then Piscator points the moral: 'I marry Sir, that was a good fish indeed : if I had had the luck to have taken up that Rod, then 'tis twenty to one, he should not have broke my line by running to the rods end as you suffered him: I would have held him within the bent of my Rod (unlesse he had been fellow to the great Trout that is near an ell 
long, which was of such a length and depth, that he had his picture drawn, and now to be seen at mine Hoste Rickabies at the George in Ware).'

Finally, let me give a less known passage. There appeared in 1646 the Shepheards Oracles, by that very real poet, Francis Quarles. He was then dead, and Walton brought out the book, and himself wrote the introduction, though Marriot the publisher signed it.

It describes Quarles going fishing on a May morning. 'He in a Sommers morning (about that howre when the great eye of Heaven first opens it selfe to give light to us mortals) walking a gentle pace towards a Brook (whose Spring-head was not far distant from his peacefull habitation) fitted with Angle, Lines and Flyes: Flyes proper for that season (being the fruitfull Month of May;) intending all diligence to beguile the timorous Trout (with which the watry element abounded), observed a more then common concourse of Shepheards, all bending their unwearied steps towards a pleasant Meadow.'

The seeming simplicity of Walton's style is its distinction : a simple Arcadian style, as Sir Walter Scott called it. It is simple to read, but it is by no means simple to write, and I really believe it has defeated everyone who has tried to copy it. There is no one exactly like him in English prose. 
Cotton, following Walton, was too good an artist to make the mistake of trying to imitate. Consequently, he was driven to the opposite extreme. And perhaps also he wrote under the influence of the sobering respectability of Walton, and had dropped the exuberant frankness of his youth. That he required correction no one who has read him will deny. His Scarronnides outraged even the easy standards of the Restoration: but though as a poet he is full of unquotable grossness, his verses have touches of observation of nature, which to tell the truth his Compleat Angler lacks. Indeed, in spite of faults, he was no mean poet : and his Poems on Several Occasions contain a good deal that might be better known than it is. The following lines are possibly his best on fishing: they are from a poem to Izaak Walton.*

If the all-ruling Power please

We live to see another May,

We'll recompence an age of these

Foul days in one fine fishing day:

We then shall have a day or two,

Perhaps a week, wherein to try,

What the best Master's hand can doe

With the most deadly killing Flie.

And these lines, too, from one of those rollicking poems which he wrote so well, are perhaps worth quoting. $\dagger$

*'To my most dear and worthy Friend, Mr. Isaac Walton,' printed in Poems on Several Occasions, 1689.

†From A Voyage to Ireland in Burlesque. ibid. 
And now farewell Dove, where I've caught such brave Dishes

Of over-grown, golden, and silver-scaled Fishes;

Thy Trout and thy Grailing may now feed securely,

I've left none behind me can take 'em so surely ;

Feed on then, and breed on, untill the next year,

But if I return I expect my arrear.

Cotton, I think, wrote better verse than prose. His prose is a little thin, and you feel it would have been better had he let himself go. In his verse he does so, sometimes no doubt to a degree which is not amusing but simply disgusting : but a great deal of it is vigorous and agreeable. On the other hand his prose, though clear and efficient, lacks colour. Still his book remains the best ever written on fly fishing.

Sir Henry Wotton, sometime Provost of Eton College, was an even better poet. He is chiefly famous for his epigram, that an Ambassador is an honest man sent to lie abroad for the good of his country. Which unluckily came to the ear of his royal master James I., who was very angry, and Wotton nearly lost his post of Ambassador at Venice. Which would have served him right; for you should not make jokes when your employer is a king who has no sense of humour. 
Wotton wrote a really beautiful poem to James I.'s daughter, the luckless Queen of Bohemia; he also wrote one of the few first-class poems on fishing. It is quite short, but a series of miniature pictures. I like them all. Take this of the trout:

The jealous Trout, that low did lie, Rose at a wel-dissembled Flie.

Or this, which might be called a vision of a fisherman's day in spring :

The showers were short; the weather mild;

The Morning fresh; the Evening smil'd.

But I like best this picture :

Jone takes her neat-rub'd paile, and now She trips to milk the Sand-red Cow;

Where, for some sturdy foot-ball Swaine, Jone strokes a sillibub, or twaine.

for it strikes that note of irrelevant beauty which great poetry gives.

Barker's ingenuous style has considerable charm, but he keeps his best for cookery, which stirred him to the depths. However, he was a crafty catcher of fish. 'The night began to alter and grew somewhat lighter : I took off the Lob-worms, and set to my Rod a white Palmer Flie, made of a large hook, I had sport for the time, till it grew lighter : then I put on my red Palmer, I had sport for the time, untill it grew very light; then I set on my black Palmer, had good sport, made up my dish of fish, put up my 
Tackles, and was at my time appointed for service. For these three Flies, with the help of the Lob-worms, serve to Angle all the year long, observing the times, as I have shewed in this nights work : a light Flie for darkness, the red Flie in medio, and a dark Flie for lightnesse.'

The following quotation, from the dedication to Edward Lord Montague, who was after.wards Earl of Sandwich and Pepys' patron, shows Barker at his most whimsical :

'Noble Lord,

'Under favour I will complement and put a case to your Honour. I met with a man, and upon our discourse he fell out with me, having a good weapon, but neither stomach nor skil; I say this man may come home by Weeping cross, I will cause the Clerk to toll his knell. It is the very like case to the gentleman Angler that goeth to the River for his pleasure: this Angler hath neither judgement nor experience, he may come home light laden at his leisure.'

The book, as was usual in the seventeenth century, had many introductory verses; perhaps these lines are worth disinterring:

Cards, Dice, and Tables pick thy purse;

Drinking and Drabbing bring a curse.

Hawking and Hunting spend thy chink;

Bowling and Shooting end in drink.

The fighting-Cock, and the Horse-race

Will sink a good Estate apace.

Angling doth bodyes exercise, 


\section{And maketh soules holy and wise: By blessed thoughts and meditation : \\ This, this is Anglers' recreation! \\ Health, profit, pleasure, mixt together, \\ All sport's to this not worth a feather.}

Franck cannot be classed with anyone else in the world. He is unique. His preface does not submit his work to the public. No. It manuducts the reader through the slender margin of his uncultivated book. When he wants to say that it is spring time, he says that the Vernon Ingress smiles. A hackle fly is not a wingless fly: nothing so simple: it is a fly which possesses indigency of wings. His political opinions necessitate his hiding himself : he takes umbrage in London. He gives an admirable account of a novice and an old hand fishing for salmon in Scotland. The novice is broken, the other successful. The novice is nervous and uncomfortable: he is described as not much deliciated. To make a fish rise is to teach him the art of invasion. And so on. But the odd thing is that it is obvious that Franck was an excellent fisherman.

Chetham, a late contemporary of Walton, supplemented the conspicuous excellence of his fly dressing by certain obscene mixtures which he recommends as 'Oyntments to alure fish to the bait.' Here is one: 'Take the Bones or Scull of a Dead-man, at the opening of a Grave, and beat the same into pouder, and put of this pouder in the Moss wherein you keep your 
Worms. But others," adds Chetham, 'like Grave Earth as well.' I can quite believe that it is equally efficacious. One of his ointments was so deadly that in his first edition he forbore to give it. It prodigiously causes fish to bite, if used by an artist. It is composed thus : Of Man's Fat, Cat's Fat, Heron's Fat, and the best Assafœetida, of each two Drams, Mummy finely powdred two Drams, mixed with various other chemicals into an indifferent thin ointment. With this anoint eight inches of your line next the hook. The Man's Fat you can get of the London Chyrurgeons concerned in anatomy, and the Heron's Fat from the poulterers; the rest are to be had from druggists. I wonder what my poulterer would say if I ordered heron's fat or my chemist if I asked him for cat's fat or mummy finely powdered. The older fishermen had some advantages over us.

These seventeenth-century writers are a wellmarked group. Except Franck, they could all write effective prose. In this they stand together, and they do so in another sense also, for they complete each other, without an undue amount of copying. When we leave them, we leave the reign of the book, and come to that of the manual. There is no great fishing prose work during the eighteenth century. And yet there are writers who deserve a mention.

Bowlker is the best. His Art of Angling was still in use as a text-book in my boyhood, 
though written considerably more than a century before I was born. In this I believe it to stand alone. True, other books have had longer lives and more editions. The Treatise, through Mascall who copied it, lasted till Walton's time. The Compleat Angler of course is still being republished every few years. But the success of Bowlker, writing in the mid-eighteenth century against numerous competitors, is far more notable than that of Dame Juliana, writing three centuries earlier against none. And Walton is reprinted not as a fisherman but as a writer. So Bowlker remains the most successful purely fishing book ever written. His prose is simple and not unpleasing. He says of fly fishing, 'Even the preparation of the Materials for the artificial Fly, and the skill and contrivance in making them, and comparing them with the natural, is a very pleasing amusement: The manner of the Fishes taking them, which is by rising to the surface of the water, and sometimes out of it, gives the Angler a very agreeable surprize.' Which is pleasantly told. Bowlker was observant of nature, and well-read in angling books. His account of the transformations of the Mayfly is worth looking at even to-day. His great merit is that he gives old ideas a good shaking up and fishing a fresh outlook. He clears away a lot of lumber. I have already told how he freed us for all time from the obsession of flies which had come down from the Treatise: flies 
which, though originally copied from living insects, had for centuries lost all touch with nature, and were slavishly inserted by succeeding writers, while even their names were corrupted. In this he gave fly fishing a new start. His position is thus not dissimilar to that of Stewart and Halford, to both of whom he presents many points of resemblance.

I believe I know the book Bowlker had in mind when he castigates certain angling treatises for mentioning flies which he never found it worth while to dress; it must have been the Gentleman Angler, 1726, by George Smith. In a bombastic preface Smith says 'I may, without Vanity, affirm, that the following Treatise upon Angling, is the most perfect and compleat of any that has hitherto appeared in Print'; and that his 'Rules and Directions are founded upon Experience, which is the most infallible Mistress, and not taken up upon Hear-say, to which little Credit is to be given.' After this it is perhaps hardly surprising to find that the only experience he had was stealing other people's ideas. He robbed not only Walton, but as far back as Mascall. However, the book has the saving grace of being printed in delightful type. And there is this, too. After giving Walton's list of flies verbatim, he says 'The best sort of A rtificial Flies are made by the ingenious Mr. Jemmit, and therefore called Jemmits Flies.' All that he tells us of the ingenious Mr. Jemmit is that he was a nice 
and complete artist. But my copy of the Gentleman Angler has this note, written in an eighteenth-century hand, possibly contemporary: 'A list of this Gent flys are handed about in Manuscript.' I would give a good deal to see that list and to know who Mr. Jemmit was. His name appeals to me : in fact all their names appeal to me, these individuals, casually mentioned in fishing books, of whom nothing else is known. Who was Captain Henry Jackson, kinsman and neighbour of Cotton, by many degrees the best fly maker he ever met, who taught him all the fly dressing he knew? Who was the very good angler whose list of flies came into Chetham's hand, since his book was almost finished at press? And who, above all, who were Merril and Faulkner, whom Franck thought so infinitely superior to Walton: and who was that paragon of them all, 'Isaac Owldham, a man that fish'd Salmon but with three Hairs at Hook'? We shall never know, alas! alas! His 'Collections and Experiments were lost with himself.' Probably future ages will not know who Dickie Routledge was, the greatest fisherman of $\mathrm{my}$ lifetime. He is dead, and his knowledge with him. His collections and experiments are lost with himself. Nor has he been described. We have no portrait of him, as we have Addison's portrait of Mr. William Wimble (brother to a baronet, and descended of the ancient family of the Wimbles); who 'makes a May-fly to a 
Miracle; and furnishes the whole country with Angle-rods." This passage, by the way, is one of the very few references to fishing to be found in general literature which is not either inaccurate or trivial. Seeing how popular fishing has been for centuries, it is strange that so little notice has been taken of it, and that little usually incorrect.

Two more prose writers of the century, and two only, shall be mentioned, one at the beginning the other at the end. Robert Howlett produced one of those treatises of which there are many, chiefly copied, but with just enough originality to escape utter plagiarism. He gives a good description of current practice in fly fishing. 'If you cannot discern your Flie upon the Water, for more Sureness, strike as soon as you perceive a Fish rises within the reach of your Rod and Line; and if you miss him, throw your Flie immediately beyond him, and draw it gently over the Place; if he like it, he will take it; and always carefully watch, that you may strike at the first rising of the Fish, when you can; and lest you should not see when you have a rise, strike so soon as you see the Line go from you; and keep your Flie always in a gentle Motion, that a fish may hang himself though you strike not.'

Thomas Best (Gent, late of his Majesty's Drawing Room in the. Tower) wrote a work which must have been exceedingly popular, for

$$
\text { *Spectator No. } 108 \text { (4 July, 1711). }
$$


it ran through thirteen editions. $\mathrm{He}$ is interesting as showing that a hundred and thirty years ago you could get good fishing in the heart of London. 'When you go to angle at Chelsea, on a calm fair day, the wind being in a right corner, pitch your boat most opposite to the church, and angle in six, or seven feet ,water, where, as well as at Battersea Bridge, you will meet with plenty of roach and dace.' I wonder how many you would meet with now. Such is the prose of the eighteenth century. There is much of it, but it is not distinguished. I come back to what I said in an earlier chapter, that the best account of fly fishing is in verse. Gay's lines are surely admirable:

Oft have I seen a skilful angler try

The various colours of the treacherous $\mathrm{fy}$;

When he with fruitless pain hath skimmed the brook,

And the coy fish rejects the skipping hook, He shakes the boughs that on the margin grow, Which o'er the stream a waving forest throw; When, if an insect fall (his certain guide), He gently takes him from the whirling tide; Examines well his form, with curious eyes, His gaudy vest, his wings, his horns and size. Then round his hook the chosen fur he winds And on the back a speckled feather binds.

Having made the fly, you proceed to try it :

Upon the curling surface let it glide, With natural motion from thy hand supplied; Against the stream now let it gently play, Now in the rapid eddy roll away. 
If you take the trouble to break through the classical crust with which that is covered, it is surely a first-rate description of fishing a fast stream. In fact I hardly know a better.

About a hundred years later another poet, a less famous name certainly, but a true poet, produced a fine fishing sonnet. Thomas Doubleday was chiefly known as an active political reformer: but he was a voluminous writer of angling songs which appeared year by year in the Newcastle Fishers Garlands and were collected by Crawhall in 1864. Good as they are, they never approach the level of his early sonnet, published in 1818 when he was eight and twenty; it is quite one of the bost things written on fishing :

Go, take thine angle, and with practised line,

Light as the gossamer, the current sweep;

And if thou failest in the calm still deep,

In the rough eddy may a prize be thine.

Say thou'rt unlucky where the sunbeams shine;

Beneath the shadow, where the waters creep,

Perchance the monarch of the brook shall leap-

For fate is ever better than design.

Still persevere; the giddiest breeze that blows, For thee may blow with fame and fortune rife;

Be prosperous-and what reck if it arose

Out of some pebble with the stream at strife,

Or that the light wind dallied with the boughs?

Thou art successful; such is human life.

These Newcastle Fishers Garlands appeared 
year by year from 1820 to 1864 : they are by different writers; of whom the best known are Thomas Doubleday and Robert Roxby. The verse often reaches a high level : but it suffers, I think, from being written in the Northumbrian dialect. I believe that dialect poetry is only good when you cannot imagine its being written as well in another medium. This is the case with Burns; for whether his Scots poetry be considered to be written in dialect or in a separate language, you cannot conceive it written as well in anything else. So it is with lesser men, such as Barnes, the Dorset poet, and perhaps with Stoddart; and, to take a living example, there is La Passion de notre frère le poilu, written by Marc Leclerc in the Anjou dialect, one of the best poems the war produced. In all these you feel the note of necessity; the poetry had to be in that medium, or not at all. I do not feel that in Doubleday, indeed his non-dialect sonnet is clearly superior.

Fishing prose came to its own again in the nineteenth century. It sprang into sudden life. One of the reasons for this has already been given: the writings of Scott and the romantic revival. The result was a second golden age, with many points of resemblance to that of Walton. If there is no single writer of his class, there is a high level of excellence. After the disappearance of Stoddart and the others of this epoch, there is another partial 
eclipse, then comes another age of great prose, that of Andrew Lang, of Lord Grey and some other living writers.

Before coming to Stoddart, it is impossible to pass over Scrope, who, though he despised the trout, is too good to be left out. $\mathrm{He}$ is one of the very best. Listen to this description of a fisherman who at last gets to the river, after eating his heart out whilst it is in flood. 'At last we started. We had about two or three miles to go to the upper cast, called the "Carrywheel." As I neared it, and saw the sweep of the gallant river, I stepped out in eagerness till I came to the top of a steep covered with wood gorse and broom; then I dashed down the rocks, and found myself on the channel, with the rush of a glorious salmon cast before me. Think of this, ye gudgeon fishers! The rod was put together in haste, - out came the London book; and whilst I selected that misnomer, a metropolitan salmon fly, a huge fish sprang out of the water before me, bright and lusty.' That is a picture we have all seen, and hope to see again. But we shall never again see Harry Otter burning the water, with Charlie and Tom Purdie, fresh from a wigging from Sir Walter Scott for getting drunk. And as fly fishers perhaps it is as well. We might be tempted.

Stoddart, who came of an old Border family, was born in Edinburgh and lived at Kelso. He fished all his life. His Art of Angling, 1835, 
was the first treatise of its kind published in Scotland. He lives, however, in his verse rather than his prose. $\mathrm{He}$ is always a poet, and always by Tweedside: thither he returns, however far he has wandered.

An' Gala, too, an' Teviot bright, An' mony a stream o' playfu' speed;

Their kindred valleys a' unite Amang the braes o' bonnie Tweed.

The Tweed, and fly fishing on the Tweed-that is what stirred him. It was for fly fishing, he says, that Thomson, Burns, Scott and Hogg, and, in his own day, Wilson and Wordsworth, exchanged eagerly the grey-goose quill and the companionship of books, for the taper wand and the discourse, older than Homer's measures, of streams and cataracts. For this Paley left his meditative home, Davy his tests and crucibles, and Chantrey his moulds, models, and chisel work. Stoddart is symbolic of his age as Walton is of his. And, though the later age produced no writer whose prose lives as does that of Walton, the two periods were not dissimilar. In both men were not ashamed to say what fishing meant to them. The later age did not say it so well as Walton, but it said it as sincerely. 'Anglers are a more gifted and higher order of men than others, in spite of the sneers of pompous critics, or the trumpery dixit of a paradoxical poet. In their histories, there are glimpses snatched out of 
heaven-immortal moments dropping from Eternity upon the forehead of 'Time,' says Stoddart, not caring whether he be thought ridiculous, for to him it was no bombast but a statement of fact. No doubt he crosses a limit which Walton would have set himself. Walton said the same thing differently. 'Indeed my good Scholar, we may say of angling, as Dr. Boteler said of Strawberries; Doubtlesse God could have made a better berry, but doubtlesse God never did; and so (if I might be Judge) God never did make a more calm quiet innocent recreation then Angling.' Walton's words will live longer than Stoddart's. But we could not afford to lose Stoddart.

There are so many contemporaries of Stoddart that choice is difficult. Penn's amusing Maxims, though getting on for a century old, are very modern. If you "pass your fly neatly and well three times over a trout, and he refuses it, do not wait any longer for him.' He can be read to-day with pleasure. So can Sir Humphry Davy and Colquhoun and Pulman, father of the dry fly. So, too, can Peter Hawker, who fished the Test on horseback. And so can many others. But there are two who stand above them all, Ronalds and Stewart. Much has been said of both, and I shall not add anything here. Stewart, whose life the Dictionary of National Biography most scandalously omits, has a style which, though simple and lucid, is damaged to my thinking 
by his use of the journalistic 'we,' which robs it of actuality. But let anyone who has not done so read him, and read in particular his fourth chapter. His creed it summed up in this sentence: 'The nearer the motions of the artificial flies resemble those of the natural ones under similar circumstances the greater will be the prospects of success.' And this, it may be remarked, sums up the creed of the dry fly also. Ronalds, twenty years earlier, had produced the best book on natural and artificial flies ever written. As prose it is not remarkable : but it will always be read.

There arose, in the years following Ronalds, a body of writers who have been somewhat neglected. Between 1847 and 1861 five really good books appeared, little studied now. Their authors were Wallwork, Wheatley, Theakston, Jackson and Wade. All are deeply stamped with the influence of Ronalds and together they form a body of doctrine standing by itself. Strangely enough, two of the five came from the Yorkshire Ure, for Theakston lived at Ripon and Jackson at Tanfield Mill, and two more, Wallwork and Wade, were north country men too. Only Wheatley came from the south. He says that his book is a sequel to Ronalds, 'not an extension of the entomological part, but an addition to the fisherman's means of successfully pursuing his favourite sport. Mr. Ronalds has confined himself wholly to nature. The angler, though generally an enthusiastic 
admirer of nature, yet uses-and with the greatest success, too-many flies (so called) and other devices wherewith nature has nothing whatever to do. These anomalies are, however, found to beguile the tenants of the stream when the charms of nature fail-a sort of Cayenne to a jaded appetite.' But Wheatley is better than he professes, for though he did not confine himself to flies, he stuck to nature, and imitated most exceeding well grasshoppers and beetles and suchlike. All the others, too, were of the naturalist school. Theakston, the most remarkable of all, would have had more influence but for his tiresome nomenclature. He cared for nothing but the fly. Study natural insects, he cries, they only are your true and permanent guides. 'This transitory book shall perish; but so long as rivers run the flies will continue to flourish in their rounds, types for the fly fisher as in days of yore, until the great doomsday volume is shut.' In this he tries to express what is at the back of all our minds, a sense of continuity. What now is has been, and will continue to be. When June comes and there are still unpolluted rivers (there will soon be mighty few unless tar-poisoning is stopped) the delicate mayfly will flicker on the water, and the great spotted trout will roll up at it, though you and I may not be there to see.

Sir Humphry Davy, earlier than Ronalds and Stewart, describes very pleasantly a day's fishing on the Colne, and many other days in 
many lands. His book is of great value. As a writer he suffers from using dialogue, which none but a master should attempt; his characters do not live, but are mere abstract arguments personified, in Charles Lamb's words. But he puts into fishing the same forceful penetration he employed in science. His book incidentally contains a fishing poem which ought to be better known than it is. $\mathrm{He}$ says that it was written in his copy of Walton by a noble lady, long distinguished at court for pre-eminent beauty and grace, whose mind possesses undying charms. Here is her invocation to Walton:
Albeit, gentle Angler, I
Delight not in thy trade,
Yet in thy pages there does lie
So much of quaint simplicity,
So much of mind,
Of such good kind,
That none need be afraid,
Caught by thy cunning bait, this book,
To be ensnared on thy hook.

which is musical, and poetry. I have seen it stated that the author was Lady Charlotte Bury. It may well be so. That beautiful and talented daughter of the fifth Duke of Argyll, the friend of Sir Walter Scott and other men of letters, was a voluminous writer, famous and popular. She was known chiefly for her anonymous Memoirs of George IV.'s Court, which caused some stir; but her novels were 
widely read, and she was a celebrity in her day.

From Stewart to the present day is some sixty years, and many have been the good books written during that time. They are too numerous even to name. I shall therefore say nothing of Henderson, who fished all his long life and wrote with equal skill: nothing of Fitzgibbon or Pennell, victor in the famous fishing duel with Stewart; nothing of Prime and Orvis and the older school of American writers; nothing of La Branche and modern American dry fly practice: nothing of Petit and the French fishermen, now an important group : nothing of many a living writer. There is much to be said about each, but to write of all would require more space than I have left, and more patience than I can expect of a reader. So I will conclude with four writers and four only. Lord Grey of Fallodon published his book at the end of last century. The dry fly was then at its zenith, and the other system was receiving somewhat intolerant treatment. He was the first writer of importance on the dry fly who really knew what the wet fly meant. Himself the best and most devoted dry fly fisherman in England, he thus started unconsciously that restatement of values which Mr. Skues has carried so far. But he did more. He is gifted with the power to write fine prose. Listen to this. After telling how Londoners who own gardens in the country realise more poignantly than others 
what they are missing when spring comes round, he goes on :

'At such moments there surges within you a spirit of resentment and indignation, kept in abeyance during the actual hours of hard work, but asserting itself at all other times, and you pass through the streets feeling like an unknown alien, who has no part in the bustle and life of London, and cannot in the place of his exile share what seem to others to be pleasures. Work alone, however interesting, cannot neutralise all this, because it is only partly by the mind that we live. Mental effort is enough for some of the satisfaction of life; but we live also by the affections, and where out-of-door things make to these the irresistible appeal, which they do make to some natures, it is impossible to live in London without great sacrifice.'

I might have quoted other passages: I quote that because it moves me most. Every fisherman who lives in a town will know.

The other three are dead. Francis Francis was for many years fishing editor of the Field, a devoted sportsman and fish preserver, and an immense writer, with a jolly captivating style. The only thing I shall quote is an epigram attributed to him: Some fishing is better than others, he said; but there is no such thing as bad fishing. Which I suspect sums up the man. It must have pleased both Walton and Stoddart, when it reached them. 
Andrew Lang has left a picture of himself fishing which will live as long as men like good fishing and good letters. But one who knew him and has fished with him many times on many waters from Galloway to Hampshire may perhaps be allowed to say that he exaggerates his deficiencies. The truth is that he loved fishing so well that he cared not if he caught fish or not. He loved the game. He was never so happy as by a river. He has told this admirable both in prose and verse; and perhaps he expresses himself best in his well-known lines :

Brief are man's days at best; perchance

I waste my own, who have not seen

The castled palaces of France

Shine on the Loire in summer green.

But no. Scotland has a nearer and dearer claim.

Nay, Spring I'd meet by Tweed or Ail, And Summer by Loch Assynt's deep, And Autumn in that lonely vale

Where wedded Avons westward sweep.

Or where, amid the empty fields, Among the bracken of the glen, Her yellow wreath October yields, To crown the crystal brows of Ken.

The Tweed was his early love, and he never changed. But afterwards I think that the Test, Itchen and Kennet claimed an equal share. 
Last of all comes Halford. His reputation as a pioneer stands high. As a writer it would stand higher had he written less. His later books show a great falling off, and indeed I do not think he ever came up to the level of his first. His prose in that is better than anything he wrote afterwards; clearer, more terse, and more pleasing. But his place does not depend on his style. There are four names which stand above others in the history of the fly: the author of the Treatise, who started it: Cotton, who established it: Stewart, who converted the world to upstream fishing : and Halford, who systematised the dry fly.

Four and a quarter centuries have gone by since the Treatise appeared. I have tried to give an account of those centuries. I hope there are some readers whom this book will interest. As I have written it, and still more as I have read over what I have written, I have been appalled at the thought that it was of no interest to anyone. Perhaps that is so. But on the other hand I know that there are some who read everything which is written about fishing, for I am of that number, and it is improbable that I am the only one. That is one consolation. And then I believe that there must be others also like myself, whom the history of the sport attracts, who are fascinated by the devices of other days, and who are never weary of going back to the old writers, of reading them again, of getting at their real 
THE LITERATURE OF FLY FISHING. 221

meaning and of seeing where they have anticipated us and where we have improved on them.

THE END. 


\section{BIBIIOGRAPHY}

OF BOOKS QUOTED OR MENTIONED.

AELIANUS, Claudius. Opera (including De animalium naturâ), Tiguri, apud Gesneros fratres, 1556. Fol. And other editions.

ALDAM, W. H. A quaint treatise on Flees, and the Art a Artyfichall Flee Making. London, 1876. 40.

ARUNDO. See BEEVER, John.

BAINBRIDGE, George C. The fly-fishers guide. Liverpool, 1816. 80. And other editions.

BARKER, Thomas. The art of angling. London, 1651. 12o. And other editions.

Barkers delight, or the art of angling. London, 1657. 120. And other editions.

BARNES, Dame Julyans. See BERNERS, Dame Juliana.

BECKFORD, Peter. Thoughts on hunting. Sarum, 1781. 40. And other editions.

(BEEVER, John.) Practical fly-fishing. By Arundo. London, 1849.120.

Do. Second edition, with author's name. Edited by A. and A. R. Severn. London, 1893. 80 .

BERNERS, Dame Juliana. The Boke of St. Albans. St. Albans, 1486. Fol. And other editions.

A treatyse of fysshynge wyth an angle. Westminster. Wynkyn de Worde. 1496. Fol. And other editions.

- An older form of the Treatyse of Fysshynge wyth an angle. London, 1883. 40.

BEST, Thomas. A concise treatise on the art of angling. London, 1787. 120. And other editions. BIACKER, William. The Art of fy-making. London, 1855. 120. 
(BLAKEY, Robert.) Hints on angling. By Palmer Hackle, Esq. London, 1846. 80.

Historical sketches of the angling literature of all nations. London, 1856.120.

BOWLKER, Richard and Charles. The art of angling by Richard Bowlker, Worcester, n.d. (1747).* 12o. Second edition, n.d. (1774) and all later editions by Charles Bowlker.

BOYLE, Hon. Robert. Occasional reflections upon several subjects. London, 1665. 120. And other editions.

BROOKES, Richard. The art of angling. London, 1740. 120 .

CARROLL, W. The angler's vade mecum. Edinburgh, 1818. 8vo.

LA CHACE DOU SERF. Anonymous. Paris, 1839. (Jubinal, Nouveaux Receuils de Contes, dits Fabliaux.) Translated into English in The Art of Hunting by Alice Dryden, q.v.

CHENEY, A. See ORVIS, Charles P.

(CHETHAM, James.) The angler's vade mecum. London, 1681. 12o. And other editions, with author's name.

(CHITTY, Edward.) The Ay-fishers text book. By Theophilus South. IJondon, 1841. 80. And another edition.

COLQUHOUN, John. The moor and the loch. Edinburgh, 1840. 8o. And other editions.

COTTON, Charles. The Compleat Angler. Part II. London, 1676. 120. And other editions.

The universal angler, made so by three books of fishing. The first by Mr. Izaak Walton; the second by Charles Cotton Esquire; the third by Colonel Robert Venables. London, 1676. 80.

- Scarronnides, or Vergile Travestie. London, 1670. 120 .

80.

COX, Nicholas. The gentleman's recreation. London, 1674. 80. And other editions.

*See note on page 89 as to date of first edition of Bowlker. 
CRAWHALL, Joseph. A collection of right merrie garlands for north country anglers. Newcastleon-Tyne, 1864. 80.

(DAVY, Sir Humphry.) Salmonia, or days of Ayfishing. By an angler. London, 1828. 80. And other editions.

D(ENNYS) J(OHN). The secrets of angling. London, 1613. 8o. And other editions.

DOUBLEDAY, Thomas. Sixty-five sonnets, with prefatory remarks on the sonnet. 1818. And see also CRA WHALL.

DRYDEN, Alice. The art of hunting. Northampton, 1908. 80.

EDMONDS, Harfield H., and LEE, Norman N. Brook and river trouting. Bradford, n.d. (1916). 80 .

ESTIENNE, Charles. L'agriculture et maison rustique. Paris, $1564 \&$ 1565. 4o. And other editions.

Maison rustique, or the countrie farme. Translated by Richard Surfleet. Augmented with additions by Gervase Markham. London, 1616. Fol. And other editions.

(FITZGIBBON, Edward.) A handbook of angling. By Ephemera. London, 1847. 80. And other editions.

- Book of the Salmon. By Ephemera. London, 1850. 80 .

FOIX, Gaston de. Le Livre de la Chasse. Paris, n.d. (1507). And other editions.

$\mathrm{F}$ (ORTIN), $\mathrm{F}$ (rère) $\mathrm{F}$ (rançois). Les ruses innocentes. Par F(rère) F(rançois) F(ortin) R(eligieux) $D(e)$ G(rammont), dit le Solitaire Inventif. Paris, 1660. 40. And other editions.

FOURNIVAL, Richard de. La vielle, ou les dernières amours d'Ovide, traduit du latin de Richard de Fournival par Jean Lefèvre. Paris, 1861. 8o.

FRANCIS, Francis. A book on angling. Iondon, 1867. 8o. And other editions.

FRANCK, Richard. Northern memoirs. London, 1694. 80 . 
New edition, by Sir Walter Scott. Edinburgh, 1821. 80 .

FROUDE, James Anthony. Short studies on great subjects. Fourth series, containing Cheneys and the house of Russell. London, 1883. 8o.

GAY, John. Poems on several occasions, containing Rural Sports. 2 vols. London, 1720. 4o. And other editions.

GREY, of Fallodon, Viscount (Sir Edward Grey). F'ly fishing. London, 1899. 80. And other editions.

HALE, J. H. How to tie salmon flies. London, 1892. 8o. And other editions.

HALFORD, Frederic M. Floating fies and how to dress them. Iondon, 1886. 8o. And other editions.

Dry-fly fishing in theory and practice. London, 1889. 8o. And other editions.

Dry-fly entomology. London, 1897. And other editions.

- The dry-fly man's handbook. London, n.d. (1913). 8o.

HAMILTON, Edward. The river-side naturalist. London, 1890. 80.

HARTLIB, Samuel. His legacy of husbandry. Third edition. London, 1655. 8o.

HAWKER, Peter. Instructions to young sportsmen in all that relates to guns and shooting. London, 1816. 8o. And other editions.

HENDERSON, William. Notes and reminiscences of my life as an angler. London, 1876. 80. Then as My life as an angler. London, 1879. So. $\mathrm{H}(\mathrm{OWLETT}) \mathrm{R}$ (obert). The anglers sure guide. Iondon, 1706. 8o.

JACKSON, John. The practical fly-fisher. London and Leeds, 1854. 80. And other editions

KELSON, George M. The salmon fly. London, 1895. 4o.

KINGSIEY, Charles. Chalk stream studies. Included in Miscellanies. 2 vol. London, 1859. 8o. Also included in Prose Idylls, London, 1873. 80 . 
LA BRANCHE, George M. L. The dry fly and fast water. New York, 1914. 8o.

LANG, Andrew. Rhymes à la mode. London, 1885. 120 .

Angling Sketches. London, 1891. 80. And other editions

LAUSON, William. See LAWSON, William.

LAWSON, William. A new orchard and garden. London, 1617-8. 4o. And other editions.

- The Secrets of angling, by I. D. Esquire. Augmented with many proved experiments, by W. Lawson. London, n.d. (1620). 8o. And other editions.

LECLERC, Marc. La passion de notre frère le poilu. Paris, 1916. 120.

LEE, Norman N. See EDMONDS, Harfield H.

LEFEVRE, Jean. See de FOURNIVAL, Richard.

LIGER, Louis. Amusemens de la campagne. 2 vols. Paris, 1709. 12o. And other editions.

MARKHAM, Gervase. A discourse of the generall art of fishing with the angle. (First printed in The Second booke of the English husbandman. London, 1614. 4o. Afterwards in The pleasures of princes, $A$ way to get wealth and other works of the author.) Many editions. See also ESTIENNE, Charles.

M(ASCALL), L(eonard). A booke of fishing with hooke and line, by L. M. London, 1590. 4o. And other editions.

MARSTON, R. B. Walton and some earlier writers on fish and fishing. London, 1894. 120.

MAXWELL, Sir Herbert. Chronicles of the Houghton Fishing Club, 1822-1908. London, 1908. 4o.

MOFFETT, Thomas. The Theater of insects. Published with Edward Topsell's History of fourfooted beasts and serpents. London, 1658. Fol.

MOTTRAM, J. C. Fly-fishing. London, n.d. 80.

MUFFET, Thomas. See MOFFETT, Thomas.

NOBBES, Robert. The compleat troller. London, 1682. 8o. And other editions.

NORTH, Christopher. See WILSON, John. 
OGDEN, James. On fly tying. Cheltenham, 1879. 8o. And other editions.

ORVIS, Charles F., and CHENEY, A. Nelson. Fishing with the fly. Manchester, Vermont, U.S.A., 1883. 120. And other editions.

PEACHAM, Henry. The compleat gentleman. London, 1627 and 1634 . 4o. And other editions.

PENN, Richard. Maxims and hints for an angler. London, 1833. 12o. And other editions.

PENNELL, Harry Cholmondeley. The modern practical angler. London, 1870. 80.

PETIT, G. Albert. La truite de rivière. Paris, 1897. 80.

PICTET, François Jules. Recherches pour servir à l'histoire et à l'anatomie des Phryganides. Geneva, Paris, and London, 1834.

- Histoire naturelle, générale et particulière, des insectes Neuroptères. 1842-5.

POPE, Alexander. Windsor Forest. London, 1713. Fol. And other editions.

POWELL, G. H. Excursions in Libraria (containing A Gascon Tragedy). London, 1895. 80.

PRIME, W. C. I go a-fishing. New York and London, 1873. 80. And other editions.

PRITT, T. E. Yorkshire trout fies. Leeds, 1885. 8o. Then as North-country fies. London, 1886.80.

PULMAN, George P. R. Vade mecum of fy-fishing for trout. London and Axminster, 1841. 120.

Second Edition. London, 1846.160.

Third Edition. London, 1851. 80.

QUARLES, Francis. The Shepheards Oracles. London, 1646.40.

RHEAD, Louis. American trout-stream insects. New York, n.d. (1916). 80.

RONALDS, Alfred. The fly-fisher's entomology. Iondon, 1836. 80. And other editions.

RUSSELI, Harold. Chalkstream and moorland. London, 1911. So.

SATCHELL, T. See WESTWOOD, T.

SAUNDERS, James. The compleat fisherman. London, 1724. 120. 
SCOTCHER, George. The fly-fisher's legacy. Chepstow, n.d. (circa 1800). 80.

SCROPE, William. Days and nights of salmon fishing in the Tweed. London, 1843. 8o. And other editions.

SHIRIEY, Thomas. The angler's museum. London, 1784. 12o. And other editions.

SKUES, G. E. M. Minor tactics of the chalk stream. London, 1910. So.

(SMITH, George.) The gentleman angler. By a gentleman. Isondon, 1726. 120. And another edition.

S(MITH), J(ohn). The true art of angling. Isondon, 1696. 240. And other editions.

(SNART, Charles.) Practical observations on angling in the river Trent. By a gentleman resident in the neighbourhood. Newark, 1801. 120.

SOUTH, Theophilus. See CHITTY, lidward.

STEWART, W. C. The practical angler. Edinburgh, 1857. 80. And other editions.

STODDART, Thomas 'Tod. The art of angling as practised in Scotland. Edinburgh, 1835. , 120. And another edition.

- Songs and poems. Jidinburgh, 1839. 8 . The angler's companion to the rivers and lakes of Scotland. Edinburgh and London, $184 \%$. 8o. Second edition. Hdinburgh and London, 1853. 80. And other editions.

___ An angler's rambles and angling songs. Edinburgh, 1866. 8o. And another edition.

TAVERNER, John. Certaine experiments concerning fish and fruite. London, 1600 . 4o.

(THEAKSTON, Michael.) A list of natural fies. Ripon, 1853. 120. And other editions.

TOD, E. M. Wet-fly fishing. London, 1903. 80. And another edition.

TOPSEL, Edward. See MOFFETT, Thomas.

TRAITTE de toute sorte de chasse et de pêche. Amsterdam, 1714. 120. A reprint of Iouis Liger's Amusemens de la campagne, q.v.

TURRELL. Ancient angling authors. London, 1910. 80 . 
TWICI, Guyllame. Le Art de Venerie. Edited by Sir Henry Dryden. Middle Hill Press, 1840. 40. (q.v.). Northampton, 1908. 80.

VENABLES, Robert. The experienced angler. London, 1662. 80. And other editions.

- The universal angler. Made so by three books of fishing. The first by Mr. Izaak Walton; the second by Charles Cotton Esquire; the third by Colonel Robert Venables. London, 1676. 80.

WADE, Henry. Halcyon. London, 1861. 80.

WALKER, Charles Edward. Old fies in new dresses. London, 1898. 8 o.

WALLWORK, James. The modern angler. Manchester, 1847. 8o.

WAITON, IZAAK. The compleat angler. London, 1653. 80. And other editions.

- The universal angler. Made so by three books of fishing. The first by Mr. Izaak Walton; the second by Charles Cotton Esquire; the third. by Colonel Robert Venables. London, 1676. 80.

WARD, Francis. Marvels of fish life. London, 1911. 80. And another edition.

- Animal life under water. London, 1919. 80. WERSTER, David. The angler and the loop-rod. lidinburgh and London, 1885.80.

WELLS, Henry $\mathbf{P}$. The American salmon fisherman. London and New York, 1886. 160.

WEST, Leonard. The natural trout $f y$ and its imitation. 1912. 8o.

WESTWOOD, T., and SATCHELL, T. Bibliotheca Piscatoria. London, 1883.80.

WHEATLEY, Hewett. The rod and line. London, 1849. 80 .

WILSON, Professor John. The recreations of Christopher North. 3 vol. Edinburgh, 1842. 8o. And other editions.

Noctes Ambrosianæ.

WOTTON, Sir Henry. Reliquice Wottoniana. London, 1651. 120. And other editions.

WRIGHT, William. Fishes and fishing. London, 1858. 80. 
YORK, Edward, Duke of. The Master of Game. Iondon, 1904. Fol. Edited by W. A. and F. Baillie-Grohman. And another edition.

YOUNGER, John. On river angling for salmon and trout. Edinburgh, 1840. 160. And other editions. 


\section{N D E X.}

ADDISON, J., 206.

AELIANUS, CLAUDIUS. De Animalium Natura describes fly fishing, 1.

d'ALBRET, JEAN, 6.

ALDAM, W. H., 125, 147, 155.

excellence of his flies, 187.

ALDER, 73, 144.

possibly in Treatise 166.

history and dressings of, 166-168.

ALDRED.

London tackle maker making three-section split cane in $1851,92$.

LE ART DE VENERIE, 5.

ARTIFICIAL FLY

copied from nature, Treatise 26, 27; Markham 71, 172; Peacham 7l; in Cotton's time 71 et seq; three schools of imitation 73-74; 141-144; Stewart 73, 142; Halford 142; colour and form 143, 144;

description of, in Treatise 25, 26; in Cotton and his contemporaries 71, 72; north and south country flies differ 71, 174; Stewart 73;

illustrations of, earliest by Lawson 42, 171, 178; Venables 171, 178; Hawkins 178; Best, 178; none good before Bowlker 178 : Excellence of Ronalds 185; his influence 186; Aldam and Blacker 187.

See also under names of individual flies-FLY DRESSINGFLY FISHING-NATURAL FLY.

'ARUNDO' (JOHN BEEVER), 26 n, 153.

AUTOPSY

first mentioned in Treatise, 27.

Chetham recommends microscope, 71 .

BAINBRIDGE, G. C., 84, 103. 
BARKER, THOMAS. $59-60,70,103-105,161$.

account of, 59, 60; place in history of fishing, 60; prose style, $60,200$.

first to use single hair, 23.

as fly dresser, $71,77,118,172-3$.

interested in cooking, 60, 72 .

and gardening, 193.

BECKFORD, PETER, 4, 84.

BEEVER, JOHN ('ARUNDO ').

Practical Fly Fishing, 26 n, 153.

BERNARD. London tackle maker, making three-section split cane in 1851, 92.

BERNERS, DAME JULIANA.

See Treatise of Fishing with an Angle.

her existence, 2, 12 and $12 \mathrm{n}$.

BEST, THOMAS, 88, 103, 105.

popularity of his work, 207; his position in history of sport, 208.

BIBLIOTHECA PISCATORIA, $89 \mathrm{n}, 181 \mathrm{n}$.

BLACK GNAT, 144, 164, 183.

first mentioned by Cotton, 164; history and dressings of, 164-165. Similarity of Halford's pattern to Cotton's, 165.

BLACK LOUPER, 26.

BLACKER, WILLIAM

his method of dressing flies, 175; first to describe detached body, 177.

BLAKEY, ROBERT, writer on fishing, 15, 106, 107.

BLUE DUN, 177, 183.

BLUE WINGED OLIVE, 73, 143.

BOOK OF ST. AIBANS, 5, 11.

its contents and character, 12.

authorship, 12, $12 \mathrm{n}$.

BOWIKKER, R. and C., 55, 88, 89, 90, 103, 105, 106, 148-158, 161,165 .

date of, $89 \mathrm{n}$.

position in history of sport, 89, 90, 204, 205.

popularity and importance, 204; his prose, 204.

rejects many useless flies, 89, 145.

BOWNESS, GEORGE. London tackle maker, 95.

BOYLE, HON. ROBERT.

account of, 118-120.

place in history of fishing, 121.

BROOKES, RICHARD, 103, 105.

BURY, LADY CHARLOTTE, 216. 
CARP.

mentioned in Treatise, 14.

CASTING THE FLY.

early method of, 24, 25.

fly must fall first, $24,25,76$.

first mention of, 42 ; in Cotton's time, 75.

CASTING LINE.

nine hairs thick recommended by Treatise, 23.

three hairs by Lawson, 23.

single hair by Barker, 23.

Cotton used single, double or treble, 24, 68, 69;

Markham's practice, 48.

of lute or viol string, mentioned by Venables and Samuel Pepys, 69.

Gut, 94, 95.

Indian Weed, 70 and $81 \mathrm{n}$.

LA CHACE DOU SERF, 1, 4.

CHETHAM, JAMES, 55, 103-105, 146, 149-156, 158.

excellence of his dressings of flies, 71, 74, 145.

ointments to allure fish, 202-203.

CHOLMONDELEY PENNELL, 108, 217.

CLARK. London tackle maker, making split cane rods in $1805,93$.

CIERK \& Co., ANDREW, of New York. early makers of six-section split cane, 94 .

COCHERIS, M., editor of La Vieille, $52 \mathrm{n}$.

COLQUHOUN, JOHN, 84, 96, 98, 103, 192, 213.

COMPLEAT ANGLER, see WALTON, IZAAK.

COPYRIGHT.

in fifteenth century, 12 ; in seventeenth, 44.

CORK BODIES FOR FLIES.

first mentioned by Mascall, 38.

COTTON, CHARLES, 56, 67, 68, 89, 103-105, 146, 148, 150-151, $154-5,159-161,163-165$.

as fly dresser, 71, 73-75, 145.

good naturalist, 182.

position in history of sport, $24,48,65,74,104,220$.

relation between him and Walton, 65, 198: its influence on his prose style, 198.

style, in prose and verse, 65, 198;

superiority of his verse, 199.

COX, NICHOLAS.

The Gentleman's Recreation, 103.

CREEL, mentioned by Dennys, 40 . 


\section{DAPPING}

mentioned by Lawson, 43 .

DAVY, SIR H., 26 n, 84, 95, 103, 106-107, 153, 192, 213. position in history of sport, 215-216.

Salmonia, its fishing excellence, 97 ; and literary faults, 97, 216.

DENISON, ALFRED.

his collection of fishing books, 13.

DENISON TEXT is earlier than text from which Treatise is printed, 13-14; is more accurate, $20 \mathrm{n}$.

DENNYS, JOHN.

Secrets of Angling, account of, 40; high position in fishing poetry, 40, 191.

DOUBLEDAY, THOMAS, 40.

DRAKE FLY, 26, 166.

DRY FLY.

anticipation of, in early writers, 116-121; Mascall, Barker and Boyle not really talking of it, 117,120 .

invention of, probable date, 115, 116.

use of, on Itchen, 115-116; by Scotcher 121, 122; Ogden 124-125; first described by Pulman, 122-124; known to Stoddart 126-127; Francis 127-129; Kingsley and Froude 128; before 1860, 128; 1860-1870, 129; work of Halford, 129-131.

partial reaction against, 131-133; case overstated by Halford, 131; work of Skues, 133.

early sale of, 125,126 .

progress since Halford, 131-134.

attraction of sport, 134-140.

DRYDEN, MISS ALICE.

The Art of Hunting, 5.

DRYDEN, SIR HENRY, translator of La Chace dou Serf, 1.

DUBRAVIUS, 59.

DUKE OF YORK.

his life and character, 7; author of Master of Game, 7-8.

DUN CUT, 26, 26 n, 39. And see YELLOW DUN.

DUN FLY, 25, 146, 151.

EDMONDS AND LEE.

Brook and River Trouting, 156.

ESTIENNE, CHARLES. author of Maison Rustique, 52; its fame, ibid.

FARLOW

London tackle maker, making three-section split cane in $1851,93$. 
FEBRUARY RED, 143, 144, 183

described in Treatise, 25,146 ;

dressing of, 146-147.

unchanged to-day, 146-147.

FERRULES

before Stewart's time, 87.

first mentioned in Treatise, 20.

FIELD, THE, articles in, 125, 127.

FISHING POETRY.

Dennys, 191; Cotton, 198-199; Wotton, 200; Lang, 219; Cochrane, 82 ; dialect poetry, 210; Barker, 201-202; Gay, 208-209; Doubleday, 209-210; Newcastle Fishers Garlands, 209-210; Lady Charlotte Bury, 216.

\section{FISHING PROSE.}

The Treatise, 30, 31, 192-193; Mascall, 193; excellence of Lawson, 194-195; Walton, 195-197; Cotton's relation to Walton, 198; criticism of Cotton's prose, 198; excellence of seventeenth century, 203; comparison between seventeenth and nineteenth centuries, 212, 213,98 ; poverty of eighteenth, $83,84,203$; influence of Walter Scott, 85, 210; eighteenth century writers, 206-208; Gay's verse better than any prose, 208; nineteenth century, Scrope, Stoddart, Stewart, Ronalds and their followers, 211-215; comparison of Stoddart with Walton, 212-213; brilliance of early nineteenth century, 96. Later writers, Lord Grey, 217-218; Francis, 218; Lang, 219; Halford, 220.

FITZGIBBON, EDWARD, 84, 103, 107, 217.

\section{FLY BOOK.}

first mentioned by Barker, 70.

FLY DRESSING.

continuity from early times to to-day, 169.

earliest directions in Barker, 172.

excellence of early imitations, 188-190.

floating flies first dressed, 177.

imitation of natural insect in Lawson, 42; Markham, 71; Peacham and Cotton, 71; in Treatise, 144-168; Markham, 144-166; Barker, 74, 172, 173; Venables, 74, 173; Cotton, 71-74, 145-176.

in seventeenth century, 71; Chetham, 145-158; Traitté, 147-168; Bowlker, 145-163; his importance, 89.

in seventeenth and eighteenth centuries the common practice is reverse winged, $174,175$.

Ronalds, 148-150, 175; his importance, 179; and influence, $180-188$.

Blacker, 175; Francis, 152-163; Halford, 148-165; Skues, 176; Stewart, 175.

Stewart's spiders, 73.

three schools of imitation 73, 74, 141-143; form and colour, 144. 
North and South country schools of dressing, 75, 174.

See also under names of individual flies-ARTIFICIAL FLYFLY FIBHING-NATURAL FLY.

FLY FISHING

in Treatise, 29-30; copy fly on water, 33-34; early writers advise keeping fly on top, 25, 77, 116-121; sunk in slow water 78; Mascall 38; Liger 55; Cotton and contemporaries 74-78; Stewart 77 .

casting, first mentioned by Lawson, 42.

different development in France and England, 49-50.

'drawing' the fly, first recommended by Markham, 47.

fishing for individual fish, Chetham, 66.

North Country school, 48.

playing a fish, in Treatise, 27-29; Lawson 42; Ronalds, 28.

popularity of, in Markham's time, 47, 48.

striking, Treatise, 38; Mascall 38; Lawson 42; Fortin, 53; in Cotton's time 78.

upstream fishing, 66, 100-110.

weather, $30,41,81$.

See also under names of individual flies-aRTIFIcIal FLYFLY DRESSING-NATURAL FLY.

DE FOIX, CATHERINE, ancestress of Henri IV., 6.

DE FOIX, COM'TE GASTON.

author of Livre de la Chasse, 5; his life and character, 6,7 ; his book, 7 .

FORTIN, FRANÇOIS.

author of Ruses Innocentes, 52; account of it, 53-54; its position in history of fishing, 53- 54 ; his debt to Treatise, 53; to Mascall, 53; excellence of illustrations, $53,171$.

FOSTER, W. H., 126.

DE FOURNIVAL, RICHARD.

early work on fishing in France, 51; account of it, 50, 51.

FRANCE. Early works on sport, 2-7; our debt to her, 11 . contrast with England, 49, 50 .

early fly fishing in, 54,55 .

fly not mentioned before eighteenth century, 49 .

IRANCIS, FRANCIS, 127, 129, 150, 152, 155, 158, 160, 162, 163, 165,189 ;

his enthusiasm for fishing, 218.

FRANCK, RICHARD, 141.

his turgid style, 57, 58, 202; his quarrel with Walton, 59. account of, $57-59$; position in history of fishing, 58, 59.

FROISSART, JEAN

visits Gaston de Foix, 6.

FROUDE, J. A., 128.

GAFF

mentioned by Barker, 70; by Venables, 79. 
GAY, JOHN, 40, 83, 84, 192, 208.

GASTON PHCEBUS. See de Foix, Count Gaston.

GINGER QUILL, 73.

GRANNOM, 73, 144, 183.

dressings of, 147-150.

is Shell Fly of Ronalds, 148; in Traitté, 150.

GREENHEART

first mentioned, 91; rejected by Stewart, 91; and Francis, 92 ; its history, 94.

GREY OF FALLODON, LORD, 3, 97, 109, 164, 211.

his importance, 217 ; his prose, $217-218$.

GUT

first mention, 94; little used in eighteenth century, 95; universal in nineteenth, 95.

HACKLE FLIES, 141.

HALE, CAPTAIN, 21, 22.

HALFORD, F. M., 86, 87, 97, 142, 148, 150, 164, 165, 192; his importance, 129-130, 220; style, 130-131, 220; criticism of his Entomology, 148, 149, 186, 187.

HAMILTON, EDWARD, 80, 186.

HARE'S EAR SEDGE, 73.

HARTLIB, SAMUEL, 181-182, 193-194.

HAWKER, PETER, 4, 213.

HAWKINS, SIR J. gives print of natural flies, 178.

HAWTHORN FLY, 74.

HAZEL.

favourite material for rods, 20.

HENDERSON, WILLIAM, 80, 217.

HICKORY, as rod material, 91.

HIGGINBOTHAM. London tackle maker

probable inventor of three or four-sectioned split cane, 98

HOOKS.

In Treatise, 21, 172; sizes 25; in Lawson 41.

Kirbys hooks, 60; eyed hook, in Fortin, 53;

double hook in Mascall 38, 73; in Venables 73.

HOWLETT, ROBERT, 88, 103, 105.

his contribution to fishing, 207.

ILLUSTRATIONS

excellence of French, 53.

see also ARTIFICIAL FLY-NATURAL FLY.

INDIAN GRASS (or INDIAN WEED), 70, $81 \mathrm{n}$. 
IRON BLOE, 144.

first mentioned by Chetham, 156; history and dressings of, 156-158.

JACKSON, CAPTAIN HENRY, 206.

JACKSON, JOHN, 103, 155, 163, 185, 214.

JACQUERIE, the. Gaston de Foix helps to quell, 6

JEMMIT, MR., his list of flies, 205-206.

JONSON, BEN.

his judgment on Markham, 43; on Donne and Shakespeare, 44.

KINGSLEY, CHARLES, 97, 128, 167.

excellence as naturalist, 186 .

KIRBY. His hooks mentioned by Barker, 60 .

LA BRANCHE, G. M. C., 217.

LAMB, CHARLES, his admiration for Walton, 196.

LANCEWOOD, used for making rods, 91.

LANDING NET,

mentioned by Dennys, 40, 79; triangular, invented by Fortin, 53, 79.

LANG, ANDREW, 40, 192, 211.

his prose, 219; poetry, 219; enthusiasm for fishing, 219 .

LAWSON, WILLIAM, 23, 37, 41, 42, 46, 47, 48. account of, 41.

as fly dresser, 46, 47.

connection with Markham, 46, 47 .

his position in history of fishing, 41-42, 48; his prose, 41; high place among fishing writers, 36, 194-195.

LECLERC, MARC, 210.

LEFEVRE, JEAN.

translated De Vetula into La Vieille, 51; account of book, 51 ; its position in history of fishing, 51, 52

LIGER, LOUIS.

author of Amusemens de la Compagne, 54; its relation to Fortin, 54; its position in history of fishing, 54, 55 .

LIGHT OLIVE, 73.

LINE (see also CASTING LINE);

of hair, in Treatise, 20, 21; in Cotton, 68, 75.

of silk and hair, mentioned by Markham, 48; condemned by Venables, 68.

of silk, first mentioned by Nobbes, 87 .

hair lines made thick for fly fishing, 68.

LITTLE, London tackle maker, making three-section split cane in 1851, 93.

LITTLE YELLOW MAY DUN, 26 and $26 \mathrm{n}$. 
MATSON RUSTIQUE, 52.

MARCH BROWN, 144, 183.

first mentioned by Chetham, 155; history and dressings of, $155-156$.

MARKHAM, GERVASE, 37, 39, 43-48, 144, 146, 151, 158, 160, $161,166,167,168,170,172$.

colourless as a writer, 195; his relation to the Treatise, 39; to Mascall, 39; to Walton, 39; his versatility, 44; his position in literature, 45 ; his debt to Dennys, 46 ; to Mascall, 47; to Lawson, 46-47; account of, 43-46; his character, $43-44$; his position in history of fishing, $46-48$; advises copying natural flies, 172 .

MARSTON, R. B.

Walton and the Earlier Fishing Writers, $22 \mathrm{n}$.

MASCALI, LEONARD, 25, 37-40, 117-118, 144, 153, 161, 163.

first English writer on fish culture, 38-39; his debt to Treatise, 25, 193; and the Dutch, 193; recommends fishing on top of water, 117-118; account of, 37; his contribution to fishing, 37,38 .

MASTER OF GAME, THE, 3, 7-11.

is model on which Treatise is founded, 9; first sporting book written in English, 8; its importance, 7, 11; model on which fishing literature was founded, 8,11

MAURE FLY, 26, 39, 161.

MAXWELL, SIR HERBERT, 128, 143.

MAYFLY, 73, 74, 143, 144, 183, 189.

probably in Treatise, 159-161; history and dressings of, 159-162; diversity of patterns, 162.

MERRIL, mentioned by Franck, 206.

MOFFETT, DR. THOMAS.

Theater of Insects, 182.

MONTAGUE, MR. R. L., 94 n.

MOORISH FLY, 145.

rejected by Bowlker, 89; and see MAURE FLY.

MORE FLY. See MAURE FLY.

MOTTRAM, J. C., 144.

MURPHY, CHARLES F., of New York, early maker of six-section split cane, 94 .

NATURAL FLY.

Knowledge of, in Tréatise, 26-27.

date of appearance known, 27 ; Cotton, 182 ; universally copied in seventeenth century, 71 ; important work of Taverner, 182; lack of scientific books in eighteenth century, 182; Moffett's Theater of Insects, 182; Bowlker, 183; Hawkins, 183; importance of Scotcher, 183; Bainbridge and Carroll, 183-184; high position of 
Ronalds, 179, 184-186, 213-214; great advance made by Pictet, 183, $185 \mathrm{n}$; Kingsley and Hamilton, 186; criticism of Halford, 148, 149, 186; West, 187; Rhead, 188.

Representations of,

Moffett, 182; Hawkins' Compleat Angler, first fishing hook which gives, 183; Scotcher first to give coloured, 183; Bainbridge, Carroll and Ronalds, 183-186; importance of Ronalds, $179,184-186$; criticism of Halford, 148, 149, 186, 187; West, 187; Rhead, 188.

See also under names of individual flies-ARTIFICIAL FLYFLY DRESBING-FLY FIBHING.

NET. See LANDING NET.

' NORTH, CHRISTOPHER,' $84,96$.

NORTH COUNTRY SCHOOL, 48, 71, 75-77, 107, 174.

NORTHERN MEMOIRS.

See FRANCK, RICHARD.

NUMBERS CAUGHT,

in Cotton's time, 79; in Waltons', 79; in Stoddart and Stewart's, 80; in nineteenth century, $80,81$.

OGDEN, JAMES.

early dry fly fisher, 124-125; and dresser, 124, 125, 160.

OINTMENTS TO ATTRACT FISH, 202.

OLIVE DUN, 144, 177.

probably in Treatise, 25, 151; history and dressings of, $150-153$.

OLIVE NYMPH, 177.

ORVIS, C. F., 217.

OWLDHAM, ISAAC.

famous fisherman mentioned by Franck, 24, 206.

PALMER FLY, meaning of, in Barker, 77.

PALE WATERY, 73.

PARTRIDGE AND ORANGE, 142.

PEACHAM, HENRY, recommends copying natural flies, 71 .

PENN, RICHARD, 84, 95, 103, 106, 107. his contribution, 213.

PEPYS, SAMUEL, mentions casting line of catgut, 69 .

PETIT, G. A., 217.

PHILLIPE, SAMUEL, probable inventor of six-section split cane, 94. 
PICTET, F. J., 128, $185 \mathrm{n}$.

POPE, ALEXANDER, 84.

POWELL, G. H., 7 n.

PRIME, W. C., 217.

PRITT, T. E., $150,154,157$.

PRUDENTIUS, 40.

PULMAN, G. P. R., 84, 103, 213.

first writer on dry fly, $97,122-124$.

QUARLES, FRANCIS. introduction of Shepheards Oracles, written by Walton, 197.

RAVENNA, BATTLE OF, 6.

RED QUILL, 143, 177.

history and dressings of, 163-164.

RED SEDGE, 144.

history and dressings of, 165-166.

not mentioned till nineteenth century, 165;

RED SPINNER, 177, 189.

mentioned in Treatise, 26, 162; by Mascall, 38, 117; in

Traitté, 164; history and dressings of, 162-164.

RED TAG, 73.

REEL,

forerunner of, used by Fortin, 53, 54; first mentioned by

Barker, 70; figured by Venables, 70; multiplying, first mentioned, 88; in general use, for salmon, 88; for trout, 88.

RHEAD, LOUIS, 188.

RINGS,

ROD.

first mentioned, 95; history of, 95.

jointed, in Treatise, 20; and ferrulled, 20, 87; spliced rod first mentioned by Lawson, 86; disappearance of spliced to-day, $86,87$.

length of, in Treatise, 23; Cotton, 23, 67; long rods used till nineteenth century, 23, 28, 85; Stewart first to advise short rod, 85 ; Halford, 86.

materials for (and see split cane below) in Treatise, 19, 20; hazel the favourite, 20, 90; whole cane, 40; Lawson, 41; Cotton, 67, 68; Venables, 68; hickory, lancewood and greenheart in nineteenth century, 90-92; greenheart disliked at first, 91, 92.

split cane, first mentioned 1801, 92; is three or foursectioned, 92; English invention, 93; inventor, 93; superseded by greenheart, 94 ; greenheart superseded by six-sectioned cane, 94 ; an American invention, 94 . in France, first mention, 52, 53. could be bought in Markham's time, 48; and Cotton's, 68. 'rush grown,' 68. 
'RODDYD' WOOL, 26.

RONALDS, ALFRED, 26 and 26 n, 84, 103, 106, 107, 148, 149 $154-158,165$.

his great importance, 179, 184-185, 213-214, and influence 186.

ROUTLEDGE, DICKIE, 81, 206.

RUDDY FLY, 39, 145.

rejected by Bowlker, 89; and see RED SPINNER.

RUSES INNOCENTES. SEe FORTIN, FRANCOIS.

'RUSH GROWN,' 68. (See ROD.)

RUSSELL, HAROLD, $115 \mathrm{n}$.

SAD YELLOW FLY, 39.

SALMON FISHING, mentioned in Treatise, 29; described by Franck, 59.

SANDY YELLOW FLY, 145. rejected by Bowlker, 89 .

SCOTCHER, GEORGE, 103, 105, 106.

his importance, 121 ; first to give coloured pictures o: natural flies, 121; precursor of the dry fly, 121-122.

SCOTT, THOMAS, quotation from, 114.

SCOTT, SIR WALTER, 84.

influence of, on fishing writers, 96; his edition of Franck 57; his criticism of Franck's style, 57, 59; and of Walton's, 59, 197.

SCROPE, WILLIAM, 24 n, 96, 98.

his prose, 211.

SHAKESPEARE, 7, 37.

SHELL FLY.

mentioned in Treatise, 26; by Ronalds, 26; and see GRANNOM.

SHERINGHAM, H. T., $185 \mathrm{n}$.

SHIRLEY, THOMAS, 103, 105, 106.

SKEAT, PROFESSOR, 13.

SKUES, G. E. M., 133, 134, 152, 157, 177.

SMITH, BARNARD, $185 \mathrm{n}$.

SMITH, GEORGE, 205.

SMITH, J., 88, 103, 104, 105.

SPENSER, EDMUND, $58 \mathrm{n}$.

SPENT OLIVE, 177.

SPORTING LITERATURE,

early, in France, 2-7; no early French books on fly, 11: in England, 7-11. 
STEWART, W. C., 98, 107, 108, 113.

position in history of sport, $48,98,213-214,220$.

his spiders, 73.

STODDART, T. T., 40, 84, 97, 103, 106, 107, 192, 210.

account of, 211-213; as a poet, 212 ; his position in history of sport, 212-213; describes dry fly, 126-127.

STONEFLY, 144.

mentioned in Treatise, 26, 158; history and dressings of, 158-159.

STRIKING

in Treatise, 78; in Cotton, 78; and see under FLY FIBHINA.

SWINBURNE, A. C., 40.

TANDY FIY, 26, 39, 159.

TAVERNER, JOHN.

his importance as observer of aquatic insects, 181, 182; and of eels, 180-181.

TAWNY FLY. See TANDY FLY.

TENNYSON, LORD, 45.

THEAKSTON, MICHAEL, 103, 145, 163, 165, 185.

his tiresome nomenclature, 215; his importance, ibid.

TOD, E. M., 152.

TOPSEL, EDWARD, 182.

TRAITTÉ DE TOUTE SORTE DE CHASSE ET DE PÊECH, $49,54,146,147,150,164,168$.

TREATISE OF FISHING WITH AN ANGLE, 2, 18, 144-148, $151,153,155,158-162,166-169,190$.

authorship and origins, $7-12,12 \mathrm{n}, 13-15,19$, 189; date, 13-14; place in history of fishing, $13,19,21-22,32-35$, 220 ; prose style, $30,31,192,193$.

TURRELL, W. J., $181 \mathrm{n}$.

TWINE FLY

rejected by Bowlker, 89 .

TWICI, WILLIAM, 5.

UPSTREAM FISHING.

first mentioned by Venables, 66, 67, 100-102; in Cotton's time, 77; importance of, 99, 101; history of, Venables to Stewart, 102-107; Stewart to present day, 107-108; comparison of up and down-stream, 109-113.

and see also under FLY FISHING.

URQUHART, SIR THOMAS, 57.

USTONSON, ONESIMUS, 88, 95.

VENABLES, ROBERT, 56, 70, 71, 99, 103, 104, 105.

account of, 60,61 ; relation to Walton, 61 ; position in history of sport, $65,75,77$; first to mention upstream fishing, 66, 67, 100-102. 
DE VETULA, 50, 51.

LA VIEILLE, 51.

WADE, HENRY, 158, 185, 214.

WADING

in time of Cotton, 78; in time of Scrope, 78.

WALKER, C. E., 168.

WALLWORK, JAMES, 121, 214.

WALTON, IZAAK, 70, 100, 117, 153, 161, 183, 191, 210.

great importance of Compleat Angler, 61, 65; his relation to the Treatise, 39, 64, 144-145; to Mascall, 25, 39, 144-145; to Markham, 144-145; to Barker, 60.

his prose, its quality, 61-65, 195-197, 213; Charles Lamb's opinion, 63, 196; and Walter Scott's, 59, 197.

his quarrel with Franck, 59.

inferiority of illustrations in Compleat Angler, 171.

ignorance of natural history, 180.

WARD, FRANCIS, 144.

WASP FLY, 26.

WEATHER,

Advice as to in Treatise, 30; by Lawson, 41; in Cotton's day, 81; for dry fly, 81.

WELLS, H. P., 86.

WEST, LEONARD, 149.

his entomological work, 187.

WHALEBONE

used for tip of rod by Fortin, 53; in Cotton's time, 68; to-day for Spey salmon rods, $68 \mathrm{n}$.

WHEATLEY, HEWETT, 185.

his contribution, 214-215.

WICKHAM, 73, 143.

WILSON, PROFESSOR JOHN, 84, 96.

WIMBLE, MR. WILLIAM, 206.

WOTTON, SIR HENRY, 40, 199.

excellence of his verse, 200 .

WRIGHT, WILLIAM, 93.

WYNKYN DE WORDE, 2, 12.

YELLOW DUN, 144.

history and dressings of, 153-155.

YELLOW FLY, 26 and $26 \mathrm{n}$.

YOUNGER, JOHN, 80, 103, 104, 106, 107. 


4

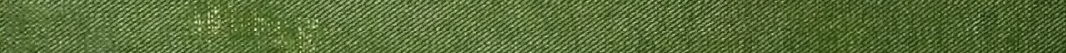

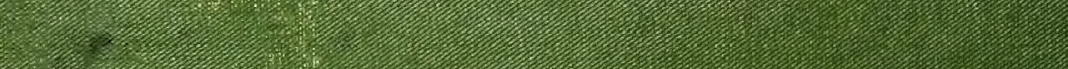

S

-

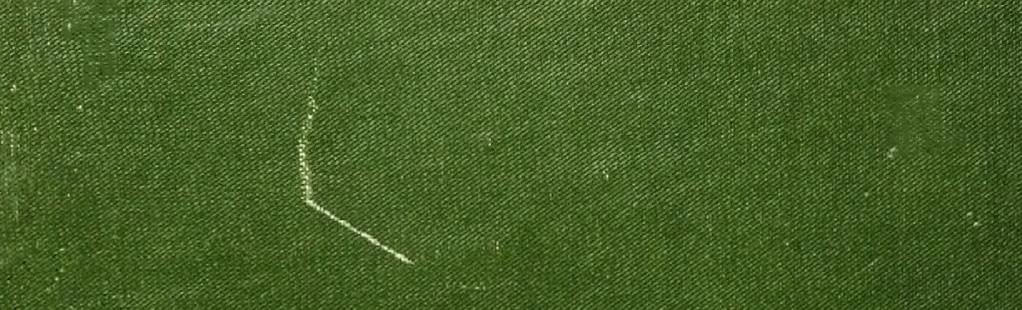

-10.0.

(3.
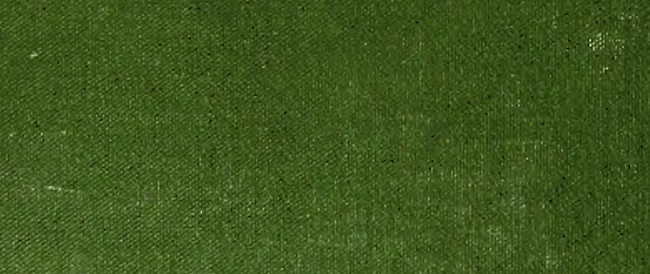

xา 8
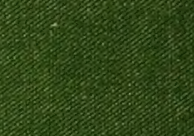